Prepared in cooperation with the Environment Agency-Abu Dhabi

\title{
Hydrogeologic Framework and Simulation of Predevelopment Groundwater Flow, Eastern Abu Dhabi Emirate, United Arab Emirates
}

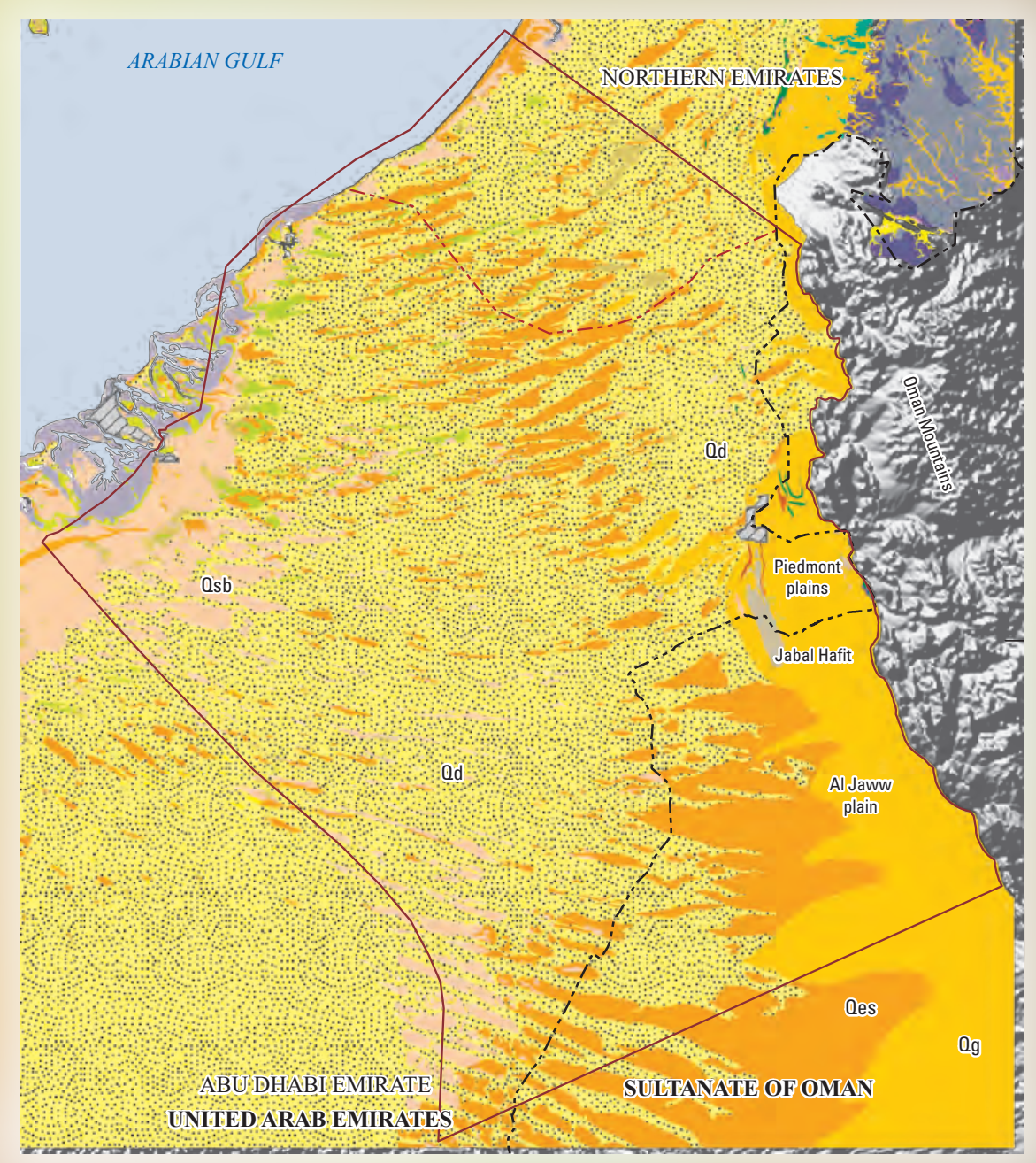

Scientific Investigations Report 2018-5158 
Cover. Figure 2 from report, showing map of physiographic settings and surficial geology of the study area, eastern Emirate of Abu Dhabi, United Arab Emirates. 


\section{Hydrogeologic Framework and Simulation of Predevelopment Groundwater Flow, Eastern Abu Dhabi Emirate, United Arab Emirates}

By Jack R. Eggleston, Thomas J. Mack, Jeffrey L. Imes, Wade Kress,

Dennis W. Woodward, and Daniel J. Bright

Prepared in cooperation with the Environment Agency-Abu Dhabi

Scientific Investigations Report 2018-5158 


\title{
U.S. Department of the Interior DAVID BERNHARDT, Secretary
}

\author{
U.S. Geological Survey \\ James F. Reilly II, Director
}

\section{U.S. Geological Survey, Reston, Virginia: 2020}

For more information on the USGS - the Federal source for science about the Earth, its natural and living resources, natural hazards, and the environment-visit https://www.usgs.gov or call 1-888-ASK-USGS.

For an overview of USGS information products, including maps, imagery, and publications, visit https://store.usgs.gov.

Any use of trade, firm, or product names is for descriptive purposes only and does not imply endorsement by the U.S. Government.

Although this information product, for the most part, is in the public domain, it also may contain copyrighted materials as noted in the text. Permission to reproduce copyrighted items must be secured from the copyright owner.

\section{Suggested citation:}

Eggleston, J.R., Mack, T.J., Imes, J.L., Kress, W., Woodward, D.W., and Bright, D.J., 2020, Hydrogeologic framework and simulation of predevelopment groundwater flow, eastern Abu Dhabi Emirate, United Arab Emirates: U.S. Geological Survey Scientific Investigations Report 2018-5158, 48 p., https://doi.org/10.3133/sir20185158.

Associated data for this publication:

Mack, T.J., Eggleston, J.R., Imes, J.L., Kress, W., Woodward, D.W., and Bright, D.J., 2020, MODFLOW-2005 groundwater flow model to simulate predevelopment groundwater flow in the eastern Abu Dhabi Emirate, United Arab Emirates: U.S. Geological Survey data release, https://doi.org/10.5066/P9ZWZISB.

ISSN 2328-0328 (online) 


\section{Acknowledgments}

The authors gratefully acknowledge H.H. Sheikh Hamdan bin Zayed Al Nahyan, Chairman of Environment Agency-Abu Dhabi (EAD), and H.E. Razan Khalifa Al Mubarak, Secretary General of EAD, whose cooperation and support have been essential to the success of this study. The authors also express their gratitude to Eng. Shaikha Ahmed Al Hosani, Acting Director, Environment Quality, for her continued support of this study and for providing access to needed datasets and reports. 



\section{Contents}

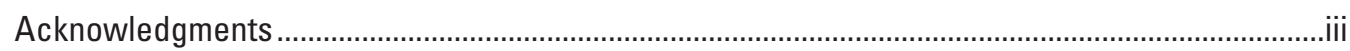

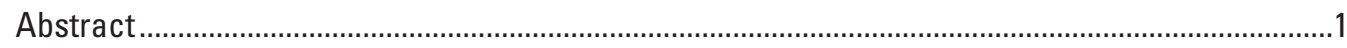

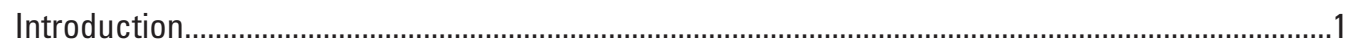

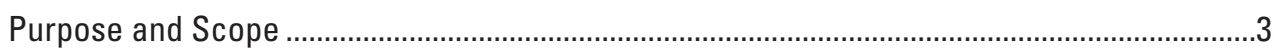

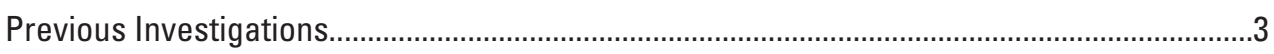

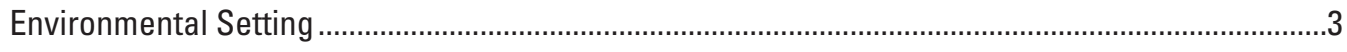

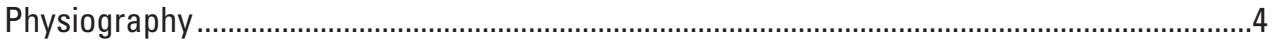

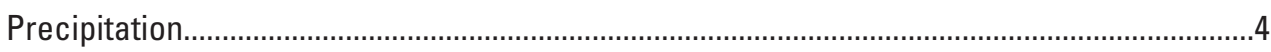

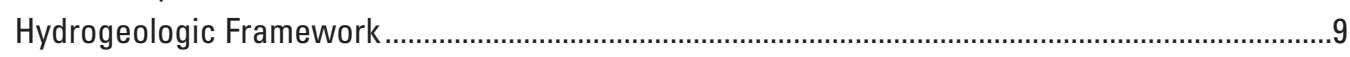

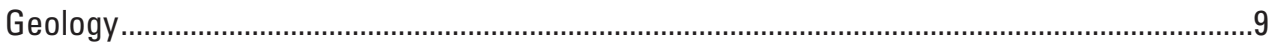

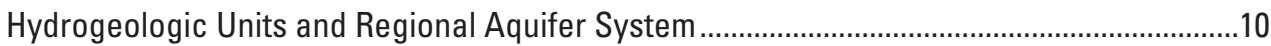

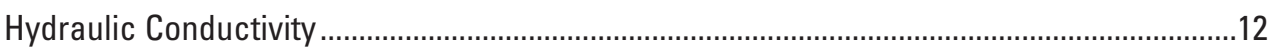

Predevelopment Groundwater Conditions .............................................................................19

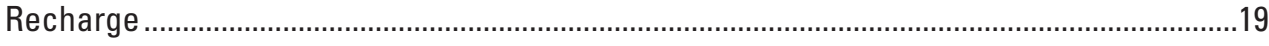

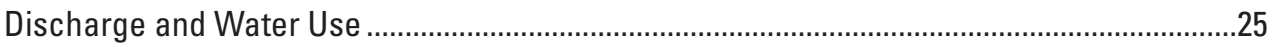

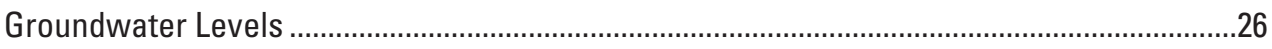

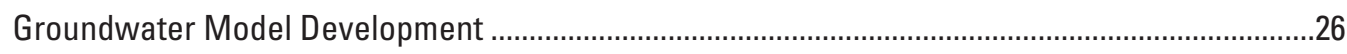

Model Discretization and Hydrogeologic Characterization ................................................28

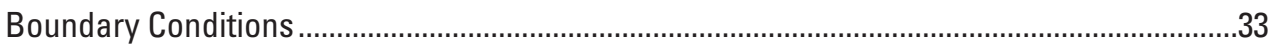

Active Model Area ....................................................................................................

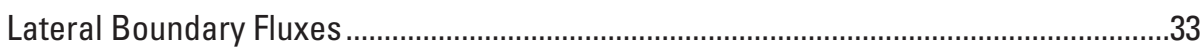

Vertical Boundaries—Recharge and Evapotranspiration ..............................................33

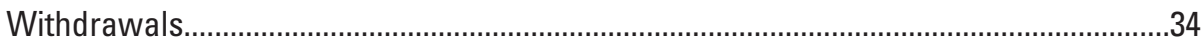

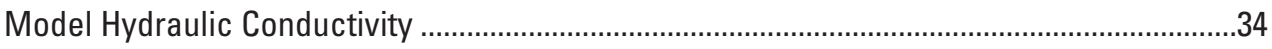

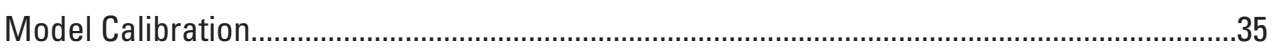

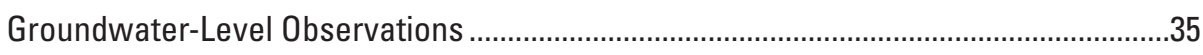

Simulated Withdrawals .........................................................................................

Sensitivity Analysis and Model Parameters …………...................................................37

Simulation of Predevelopment Groundwater Flow .....................................................................4

Model Scenarios and Effects of Different Recharge Components .........................................4

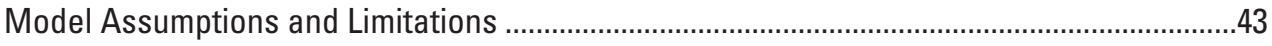

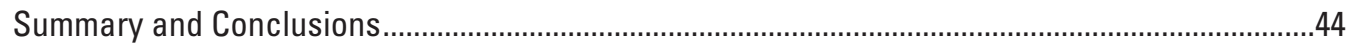

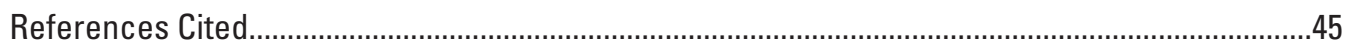




\section{Figures}

1. Map showing the study area, eastern Emirate of Abu Dhabi, United Arab Emirates.......2

2. Map showing physiographic settings and surficial geology of the study area, eastern Emirate of Abu Dhabi, United Arab Emirates

3. Map showing meteorological stations and mean annual precipitation, based on data from 1982 to 2013, eastern Emirate of Abu Dhabi, United Arab Emirates.

4. Graphs showing $A$, mean annual precipitation from 1982 to 2013 at 23 meteorological stations and $B$, annual total precipitation at 3 stations from 1975 to 2013, eastern Emirate of Abu Dhabi, United Arab Emirates

5. Cross-section showing generalized west-east hydrogeology in Emirate of Abu Dhabi, United Arab Emirates

6. Map showing surficial geology and extent of hydrogeologic units, eastern Emirate of Abu Dhabi, United Arab Emirates.

7. Graph showing hydraulic conductivity of surficial aquifer and deep sediments by category, based on percentage of test interval within the surficial aquifer

8. Maps showing median hydraulic conductivity values of surficial and deep aquifer sediments, based on percentage of test interval, in the surficial aquifer in $A$, category $1, B$, category $2, C$, category 3 , and $D$, category 4 , for the eastern Emirate of Abu Dhabi, United Arab Emirates.

9. Illustration showing mountain-front recharge and lateral inflow from the Oman Mountains to the aquifer, eastern Emirate of Abu Dhabi, United Arab Emirates

10. Illustration showing a generalized conceptual model of precipitation, recharge, and evapotranspiration on sand dunes and desert plains

11. Map showing model boundary conditions and grid spacing, eastern Emirate of Abu Dhabi, United Arab Emirates

12. Map showing Aflaj locations in the Al Ain area of the study area, eastern Emirate of Abu Dhabi, United Arab Emirates

13. Map showing locations of observed predevelopment groundwater levels and interpolated predevelopment water-table surface, eastern Emirate of Abu Dhabi, United Arab Emirates

14. Map showing active areas in model layers $1-5$ and approximate model bottom elevation, eastern Emirate of Abu Dhabi, United Arab Emirates.

15. Cross section showing generalized model layers and representation of hydrogeologic units for the predevelopment groundwater flow model of the eastern Emirate of Abu Dhabi, United Arab Emirates

16. Graphs showing $A$, observed and simulated groundwater levels, $B$, weighted residual and simulated groundwater levels, and $C$, observed and simulated aflaj flows for the predevelopment groundwater flow model of the eastern Emirate of Abu Dhabi, United Arab Emirates

17. Map showing simulated predevelopment groundwater contours and contours interpreted from Imes and Clark (2006), eastern Emirate of Abu Dhabi, United Arab Emirates

18. Graphs showing ranked parameter sensitivities, showing contributions from different observation groups, for model parameters for four groundwater flow model scenarios, predevelopment groundwater flow model of the eastern Emirate of Abu Dhabi, United Arab Emirates.

19. Graphs showing 95-percent confidence intervals for normalized parameter estimates for four groundwater flow model scenarios, predevelopment groundwater flow model of the eastern Emirate of Abu Dhabi, United Arab Emirates. 


\section{Tables}

1. Meteorological stations and observed mean annual precipitation, eastern Emirate of Abu Dhabi, United Arab Emirates.....

2. Descriptions of hydrogeologic units in the eastern Emirate of Abu Dhabi, United Arab Emirates

3. Summary of estimated annual volumetric and linear rates of natural aquifer recharge, and recharge as a percentage of precipitation, by recharge component, modified from Osterkamp and others (1995)

4. Model parameters for hydrogeologic units and boundary conditions for four model scenarios, eastern Emirate of Abu Dhabi, United Arab Emirates.

5. Model-calculated predevelopment water balance and components of flow for four model scenarios, eastern Emirate of Abu Dhabi, United Arab Emirates

\section{Conversion Factors}

International System of Units to U.S. customary units

\begin{tabular}{|c|c|c|}
\hline Multiply & By & To obtain \\
\hline \multicolumn{3}{|c|}{ Length } \\
\hline millimeter (mm) & 0.03937 & inch (in.) \\
\hline meter $(\mathrm{m})$ & 3.281 & foot $(\mathrm{ft})$ \\
\hline kilometer (km) & 0.6214 & mile (mi) \\
\hline meter $(\mathrm{m})$ & 1.094 & yard (yd) \\
\hline \multicolumn{3}{|c|}{ Area } \\
\hline square kilometer $\left(\mathrm{km}^{2}\right)$ & 247.1 & acre \\
\hline square meter $\left(\mathrm{m}^{2}\right)$ & 10.76 & square foot $\left(\mathrm{ft}^{2}\right)$ \\
\hline square kilometer $\left(\mathrm{km}^{2}\right)$ & 0.3861 & square mile $\left(\mathrm{mi}^{2}\right)$ \\
\hline \multicolumn{3}{|c|}{ Flow rate } \\
\hline meter per day $(\mathrm{m} / \mathrm{d})$ & 3.281 & foot per day $(\mathrm{ft} / \mathrm{d})$ \\
\hline meter per year (m/yr) & 3.281 & foot per year ft/yr) \\
\hline cubic meter per second $\left(\mathrm{m}^{3} / \mathrm{s}\right)$ & 35.31 & cubic foot per second $\left(\mathrm{ft}^{3} / \mathrm{s}\right)$ \\
\hline cubic meter per day $\left(\mathrm{m}^{3} / \mathrm{d}\right)$ & 35.31 & cubic foot per day $\left(\mathrm{ft}^{3} / \mathrm{d}\right)$ \\
\hline liter per second $(\mathrm{L} / \mathrm{s})$ & 15.85 & gallon per minute (gal/min) \\
\hline cubic meter per day $\left(\mathrm{m}^{3} / \mathrm{d}\right)$ & 264.2 & gallon per day (gal/d) \\
\hline millimeter per year (mm/yr) & 0.03937 & inch per year (in/yr) \\
\hline million cubic meters per year $\left(\mathrm{Mm}^{3} / \mathrm{yr}\right)$ & 810.7 & acre foot per year (acre-ft/yr) \\
\hline \multicolumn{3}{|c|}{ Hydraulic conductivity } \\
\hline meter per day $(\mathrm{m} / \mathrm{d})$ & 3.281 & foot per day (ft/d) \\
\hline \multicolumn{3}{|c|}{ Transmissivity } \\
\hline meter squared per day $\left(\mathrm{m}^{2} / \mathrm{d}\right)$ & 10.76 & foot squared per day $\left(\mathrm{ft}^{2} / \mathrm{d}\right)$ \\
\hline
\end{tabular}




\section{Datum}

Horizontal coordinate information is referenced to Nahrwan 1967/Universal Transverse Mercator zone 40N, which uses the Nahrwan 1967 geographic two-dimensional coordinate reference system and the Universal Transverse Mercator zone 40N as its projection.

Elevation, as used in this report, refers to distance above sea level as reported in the Global Digital Elevation Model version 2 (ASTER GDEM Validation Team, 2011).

\section{Supplemental Information}

Concentrations of chemical constituents in water are given in milligrams per liter (mg/L).

\section{Abbreviations and Acronyms}

$\begin{array}{ll}\text { ASTER } & \text { Advanced Spaceborne Thermal Emission and Reflectance Radiometer } \\ \text { CSS } & \text { composite scaled sensitivities } \\ \text { EAD } & \text { Environment Agency-Abu Dhabi } \\ \text { ET } & \text { evapotranspiration } \\ \text { GDEM } & \text { Global Digital Elevation Model } \\ \text { GTZ } & \text { Deutsche Gesellschaft für Technische Zusammenarbeit } \\ \text { GWA } & \text { Groundwater Assessment Project in Abu Dhabi, 10-year German groundwater } \\ & \text { study program } \\ \text { GWRP } & \text { Ground Water Research Program, a cooperative USGS and National Drilling } \\ \text { HGU } & \text { Company program } \\ \text { HK } & \text { hydrogeologic unit } \\ \text { IWRAG } & \text { horizontal hydraulic conductivity } \\ \text { NDC } & \text { inter-wadi recharge above outcrop gaps } \\ \text { S } & \text { National Drilling Company, subsidiary of Abu Dhabi National Oil Company } \\ \text { USGS } & \text { specific yield } \\ \text { UAE } & \text { U.S. Geological Survey } \\ \text { VK } & \text { United Arab Emirates } \\ & \text { vertical hydraulic conductivity }\end{array}$




\title{
Hydrogeologic Framework and Simulation of Predevelopment Groundwater Flow, Eastern Abu Dhabi Emirate, United Arab Emirates
}

\author{
By Jack R. Eggleston, Thomas J. Mack, Jeffrey L. Imes, Wade Kress, Dennis W. Woodward, and \\ Daniel J. Bright
}

\section{Abstract}

Groundwater in eastern Abu Dhabi in the United Arab Emirates is an important resource that is widely used for irrigation and domestic supplies in rural areas. The U.S. Geological Survey and the Environment Agency-Abu Dhabi cooperated on an investigation to integrate existing hydrogeologic information and to answer questions about regional groundwater resources in Abu Dhabi by developing a numerical groundwater flow model based on MODFLOW-2005 software.

The groundwater flow model developed in this investigation provides an improved understanding of groundwater conditions in the eastern region of the Emirate of Abu Dhabi. The flow model simulates steady-state predevelopment conditions from before the rapid growth of modern pumping in the 1980s and was calibrated with 1,342 groundwater-level observations by use of automated and manual calibration techniques. The calibrated model provides good accuracy, with a mean error of 0.50 meters and a standard error of 5.92 meters for simulated groundwater levels. The results of the regional water budget simulation show that gap recharge, which is groundwater inflow through mountain-front gap alluvium, is the greatest source of water to the aquifer. In the base simulation scenario, gap recharge represents 80 percent of total inflow $(119,470$ of 149,403 cubic meters per day) and the greatest outflow from the aquifer is from evapotranspiration (93 percent of total outflow). Model scenario and sensitivity results reveal a need for data that more thoroughly and more accurately describe aquifer hydraulic conductivity, inflow to the aquifer from the Oman Mountains, and recharge from precipitation on the piedmont. Additional long-term aquifer pumping test observations would improve understanding of aquifer hydraulic conductivity, which would also improve model accuracy. Future studies can modify the model to understand the effect of land-use change and water use on groundwater supplies and simulate more complex groundwater flow conditions in a predictive mode.

\section{Introduction}

The Emirate of Abu Dhabi in the United Arab Emirates (UAE) has experienced considerable economic and population growth during recent decades. This growth has increased the demand for water and caused a corresponding increase in groundwater withdrawals that, in some areas, has dewatered the surficial aquifer, the primary water-producing aquifer. Changes in water use, including increased groundwater withdrawals and increased use of desalinated water supplies, have implications for groundwater resource availability that are currently (2016) poorly understood. The U.S. Geological Survey (USGS) and the Environment Agency-Abu Dhabi (EAD) cooperated on an investigation to assess both the regional groundwater flow system and the utility of existing data to describe the flow system in a 27,000-square-kilometer $\left(\mathrm{km}^{2}\right)$ area of the eastern region of the Abu Dhabi Emirate (fig. 1), referred to in this report as the "study area." A preliminary groundwater flow model was developed and calibrated for steady-state simulations of predevelopment groundwater conditions - conditions existing prior to the widespread adoption of modern well drilling and electrically powered well pumps, or approximately pre-1980. This study had three goals:

1. Compile existing hydrogeologic data and build a conceptual model of groundwater resources in the study area.

2. Develop and calibrate a steady-state numerical groundwater flow model to simulate regional, predevelopment groundwater flow.

3. Use the model to help assess the quality of existing data, identify gaps in data necessary for understanding the groundwater flow system, and prioritize efforts for further investigation of groundwater resources in the study area.

The scope of this investigation was regional, encompassing the eastern region of the Abu Dhabi Emirate from the Arabian Gulf to the Oman Mountains. The steady-state groundwater flow model developed in this study simulates average predevelopment groundwater flow conditions, which existed prior to 1980 . 


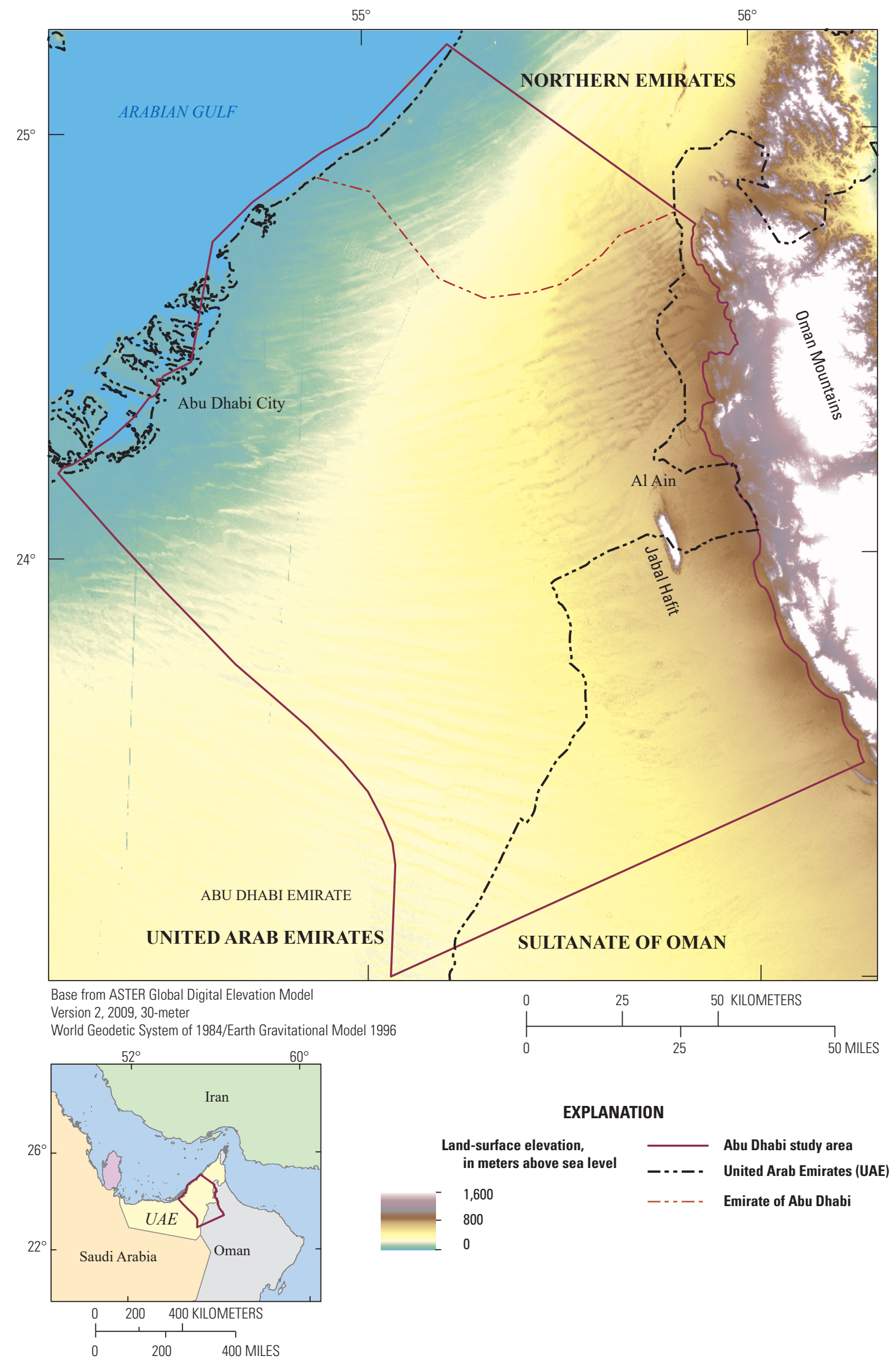

Figure 1. The study area, eastern Emirate of Abu Dhabi, United Arab Emirates. 
The USGS has studied the geohydrology of the Abu Dhabi Emirate since 1988, when a partnership was formed with the National Drilling Company (NDC), a subsidiary of Abu Dhabi National Oil Company. In 2013, the USGS began a partnership with EAD to analyze existing data and investigate groundwater availability through the development of a preliminary numerical groundwater flow model of the study area.

\section{Purpose and Scope}

This report describes the groundwater flow system in the eastern region of Abu Dhabi Emirate, under predevelopment conditions, and documents the data compilation and analytical methods used to prepare inputs for the simulation model. The report also describes the preliminary groundwater flow model, simulated predevelopment groundwater conditions prior to 1980, and model scenarios that evaluate the effects of different recharge components.

\section{Previous Investigations}

Among the earliest regional groundwater studies in eastern Abu Dhabi, Gibb and Partners (1969; 1970a, b) provided an initial understanding of freshwater resources by reporting on groundwater levels, flows in aflaj (underground channels), and precipitation and evaporation rates. Similarly, Halcrow and Partners (1969a-c) described water-resources in the northern Emirates, with estimated values or observations informing descriptions of climate, hydrogeology, surface water, and groundwater. In the 1970s, Hydroconsult (1978) was the first study to quantify the regional groundwater resources of the sand dune area north and west of Al Ain, the largest city in eastern Abu Dhabi (fig. 1). A program of deep water well drilling in the United Arab Emirates by Geoconsult and Bin Ham Well Drilling Establishment (1985a-c) resulted in a better understanding of the potential of deep bedrock units to provide substantial volumes of fresh groundwater in eastern Abu Dhabi. Another such series of reports, by Consultants for Water and Environment and Bin Ham Well Drilling Establishment (1986a-e), described drilling and geophysical studies near Al Ain and in the sand dune area south and west of $\mathrm{Al}$ Ain.

In the late 1980s and mid-1990s, two investigative programs were launched that were dedicated to intensive assessments of the groundwater resources of Abu Dhabi Emirate. The first program began in 1988 when the USGS entered into a cooperative program with NDC to investigate groundwater resources, conduct research, and provide groundwater training for NDC staff. The cooperative program, referred to as the USGS-NDC Ground Water Research Program (GWRP), produced more than 200 scientific reports on the groundwater resources of Abu Dhabi Emirate (USGS, 2013); the initial phase of that investigation focused on the eastern region of the Abu Dhabi Emirate (fig. 1). During the early 1990s, the GWRP developed a digital finite-difference model and assessment of groundwater flow in the eastern region of the Abu
Dhabi Emirate (Imes and others, 1993). Available geologic and hydrologic data were used to build that early model; the data included the interpretation of 94 industry seismic lines (approximately 2,800 kilometers [km]), of which 33 lines were reprocessed to provide greater detail of the shallow (less than 600 meters [m]) subsurface. The original seismic sections were interpreted by the GWRP to delineate the locations and orientation of major faults and folds and to provide a depositional and deformational history (Woodward and Al-Jeelani, 1993; Woodward, 1994).

The second program began in 1995 to evaluate the yield of deep sediments and potential aquifers in the Emirate of Abu Dhabi. The Groundwater Assessment Project in Abu Dhabi (GWA) was a 10-year program jointly implemented by a consortium of two German companies-Deutsche Gesellschaft für Technische Zusammenarbeit (GTZ) and Daimler-Benz Aerospace, Dornier System Consult-in cooperation with the Abu Dhabi National Oil Company for the Government of Abu Dhabi Emirate. Numerous status reports document the data and information collected and analyzed by this project (GTZ/ Dornier Consult, 2005), which ended in 2005. Selected field data from this assessment were used in this report.

Hydrogeologic data and studies from the GWRP and GWA programs were available to guide development of the groundwater model presented here. Results from these studies were compiled from publicly available journal articles, books, and reports; USGS field records; and administrative technical reports. Administrative reports cited in this study are used with permission and are available, by request, from EAD. The seismic data and borehole lithologic and geophysical logs were used in this study to better define the extent and stratigraphy of hydrogeologic units in the study area.

\section{Environmental Setting}

Previous studies have divided the Emirate of Abu Dhabi (Emirate) into western and eastern physiographic regions, the boundary between which is approximately coincident with a regional groundwater divide (Hutchinson, 2006). The study area (fig. 1) includes much of the eastern region and contains the largest population centers in the Emirate, the coastal city and capital Abu Dhabi and the inland "Garden City" of Al Ain. Land elevations in the study area increase gradually over a distance of about $140 \mathrm{~km}$, from sea level along the gulf coast to about $280 \mathrm{~m}$ in $\mathrm{Al} \mathrm{Ain}$, and then sharply rise to over 1,100 $\mathrm{m}$ in the Oman Mountains along the eastern border of the Emirate (fig. 1).

The western and eastern physiographic regions of the study area are separated by a series of sabkhas (salt flats) that coincide with a groundwater flow divide trending southeast from about $40 \mathrm{~km}$ west of the city of Abu Dhabi to the southeastern corner of the Emirate (Imes and Clark, 2006, fig. 4). In the eastern region, groundwater generally flows from the Oman Mountains along the eastern border towards the Arabian Gulf and sabkha deposits that form the southwestern 
border of the eastern region. The northwest-southeast-trending sabkha deposits, therefore, represent a regional area of natural groundwater discharge where the depth to groundwater is shallow and discharge occurs by evaporation (fig. 2). This groundwater flow divide forms the southwestern boundary of the study area.

\section{Physiography}

The eastern region can be divided into the following three general physiographic areas: coastal marine, internal sand dunes, and piedmont plains (fig. 2; Hutchinson, 2006). Eolian sand dunes cover most of the inland areas of the eastern region, with generally red-orange quartz-sand dunes in the east, grading to whiter carbonate-sand dunes in the west and closer to the coast. Sand dune areas have been classified in the northern half of the region (Gillespie and Mohamed, 2006) as east-west compound linear dunes from 50 to $60 \mathrm{~m}$ in height with interdunal areas typically consisting of thin sheets of sand to the east and grading to interdunal sabkhas to the west. In the southern half of the region, northwest-southeast rectangularlinear dunes with relatively wide, flat interdunal sabkhas are present. For most areas of the Emirate, interdunal sabkhas generally consist of thinly bedded deposits of sand, silt, and evaporite, with no or sparse natural vegetation.

The coastal marine area adjacent to the Arabian Gulf is dominated by sabkha and tidal flat deposits (Gillespie and Mohamed, 2006). In the northeast coastal marine areas, paleodune deposits are present within the sabkha and tidal flat areas. Towards the northwest, the paleodune deposits grade into predominantly coastal terrace deposits. The city of Abu Dhabi is in the coastal marine region.

The piedmont plains are along the eastern border with Oman (fig. 2) and include the second largest city in the Emirate, Al Ain (figs. 1 and 2). The piedmont plains are characterized by fluvial sediments with coalescing alluvial fans and gravel plains that slope gently westward from the Oman Mountains. Just south of Al Ain, the coalescing fans and gravel plains abut Jabal Hafit, a large carbonate outcrop that rises more than $1,000 \mathrm{~m}$ above the valley floor on the west side of Al Jaww plain (fig. 2). In the northern part of the piedmont, inland dunes cover the western extension of the piedmont plain. In all areas of the piedmont, alluvial fans and gravel plains are dissected by ephemeral-flowing wadis (riverbeds) exiting the western side of the Oman Mountains at erosional gaps along the mountain front. Wadis in the study area generally have broad channel floors lined with sand and gravel and are typically incised less than $3 \mathrm{~m}$, and some contain a complex braided pattern of internal channels and bars. Other than ephemeral storm runoff in the wadis and a few mountain springs, there is no natural surface water in the study area.

\section{Precipitation}

Climate in the eastern region transitions from arid in the Oman Mountains to hyperarid in the sand dune area (Food and Agriculture Organization, 2009). Arid climates are those with an aridity index (mean annual precipitation divided by mean annual potential evapotranspiration) of $0.05-0.2$, and hyperarid climates are those with an aridity index of less than 0.05 . Most precipitation typically occurs in winter months, from January to April (Brook, 2006); however, appreciable precipitation can also occur from summer monsoon storms. Mean monthly precipitation records (National Center of Meteorology and Seismology, 2016) indicate that most summer precipitation occurs during July and August, producing thundershowers in the Oman Mountains and southeastern parts of the region (Gillespie and Mohamed, 2006).

Data describing precipitation at 28 meteorological stations and covering the period from 1982 to 2013, for the longest period of record, were evaluated to determine mean precipitation and its spatial distribution (table 1 and fig. 3). Mean annual precipitation was spatially interpolated across the study area using inverse-distance weighting. The Al Qattara and Um Ghafa stations were excluded from interpolation because they have short periods of record and their mean annual precipitation values of 13.0 and 41.4 millimeters per year $(\mathrm{mm} / \mathrm{yr})$ were markedly lower than values at nearby stations with longer records. To allow interpolation beyond the geographic range of the 28 meteorological stations, mean annual precipitation values were estimated at 12 locations to the south, east, and west of the study area (not shown on map); assumed values for the interpolation were set equal to the nearest measured value.

Across the eastern region, precipitation generally increases to the east and north and decreases to the south and west. Precipitation data indicate a mean annual precipitation of $60.1 \mathrm{~mm} / \mathrm{yr}$ for the 23 meteorological stations within the United Arab Emirates (UAE) study area (figs. 3 and $4 A$, table 1). Precipitation higher than the overall mean was recorded at stations located on the piedmont plain (Al Foah, Khatam Al Shaklah, Mezyad, and Jabal Hafit), with mean annual values ranging from about $77-110 \mathrm{~mm} / \mathrm{yr}$. Precipitation lower than the overall mean was recorded at stations located in the sand dune or coastal marine regions. Mean annual precipitation values for Abu Dhabi airport and Al Khazna stations were slightly higher than values for surrounding stations; mean annual precipitation for the Rowdah station was slightly lower than values for surrounding stations. The mean length of record for the 23 meteorological stations in the study area is 12.6 years, the longest record is for Abu Dhabi airport, which has a continuous record from 1982 to 2013 (fig. 4B). Because the length of record, even for Abu Dhabi airport, is short compared to the large variability of annual precipitation values, uncertainty in estimates of annual mean precipitation is relatively high for most stations, with a mean standard error of $13.8 \mathrm{~mm} / \mathrm{yr}$ (fig. $4 A$ ). It is possible that precipitation for the predevelopment period and earlier, based on precipitation trends and aflaj flows (discussed in the "Discharge and Water Use" section), might have been greater than the mean annual precipitation since 1975 (Jorgensen and al-Tikiriti, 2002). 


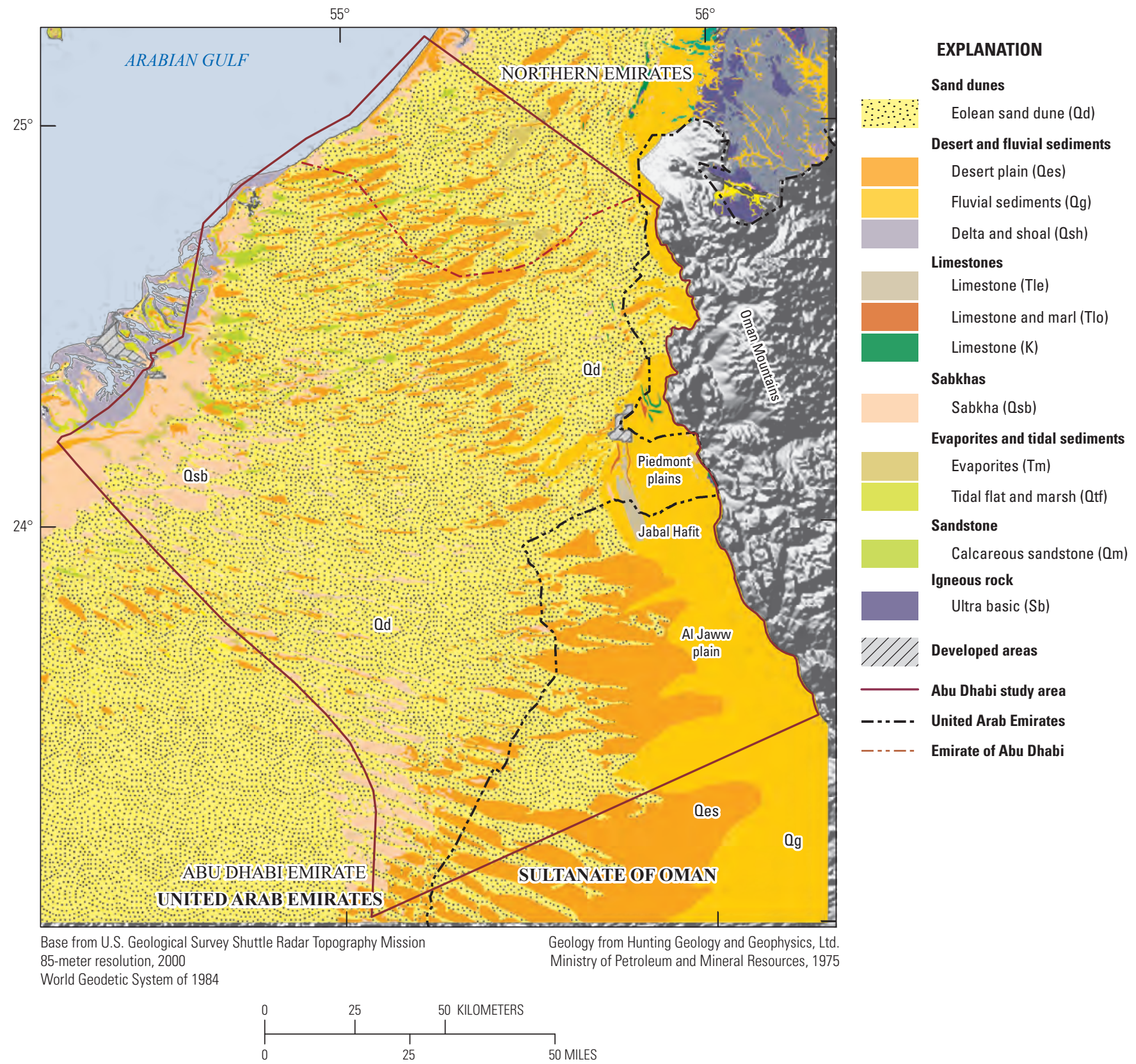

Figure 2. Physiographic settings and surficial geology of the study area, eastern Emirate of Abu Dhabi, United Arab Emirates. 
Table 1. Meteorological stations and observed mean annual precipitation, eastern Emirate of Abu Dhabi, United Arab Emirates.

[Station locations are shown on figure 3 unless otherwise indicated. m, meter; DDLat, latitude in decimal degrees; DDLon, longitude in decimal degrees; mm, millimeter; min, minimum; max, maximum; stdev, standard deviation; stderr, standard error]

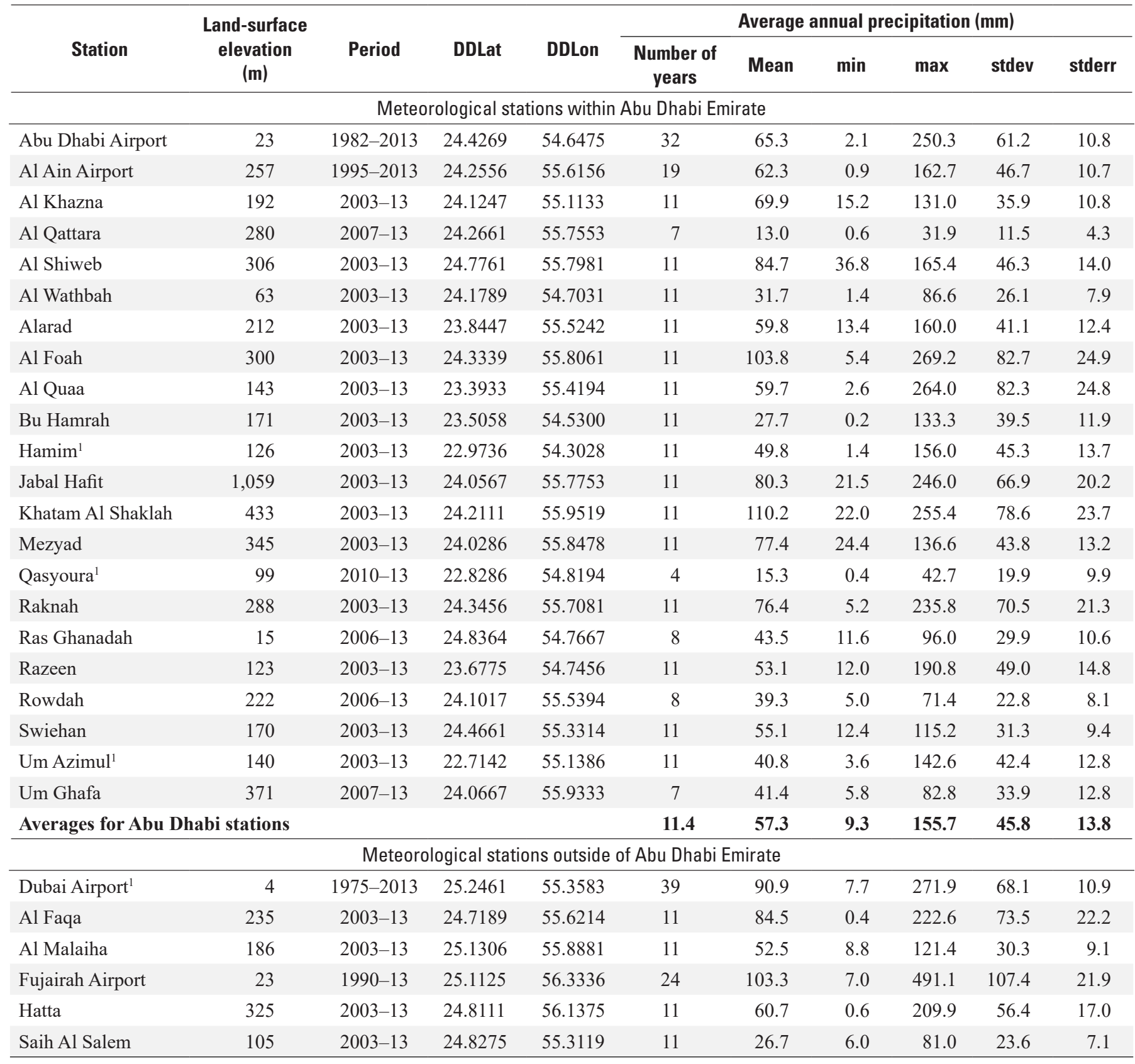

\footnotetext{
${ }^{1}$ Outside of study area and not shown on figure 3.
} 


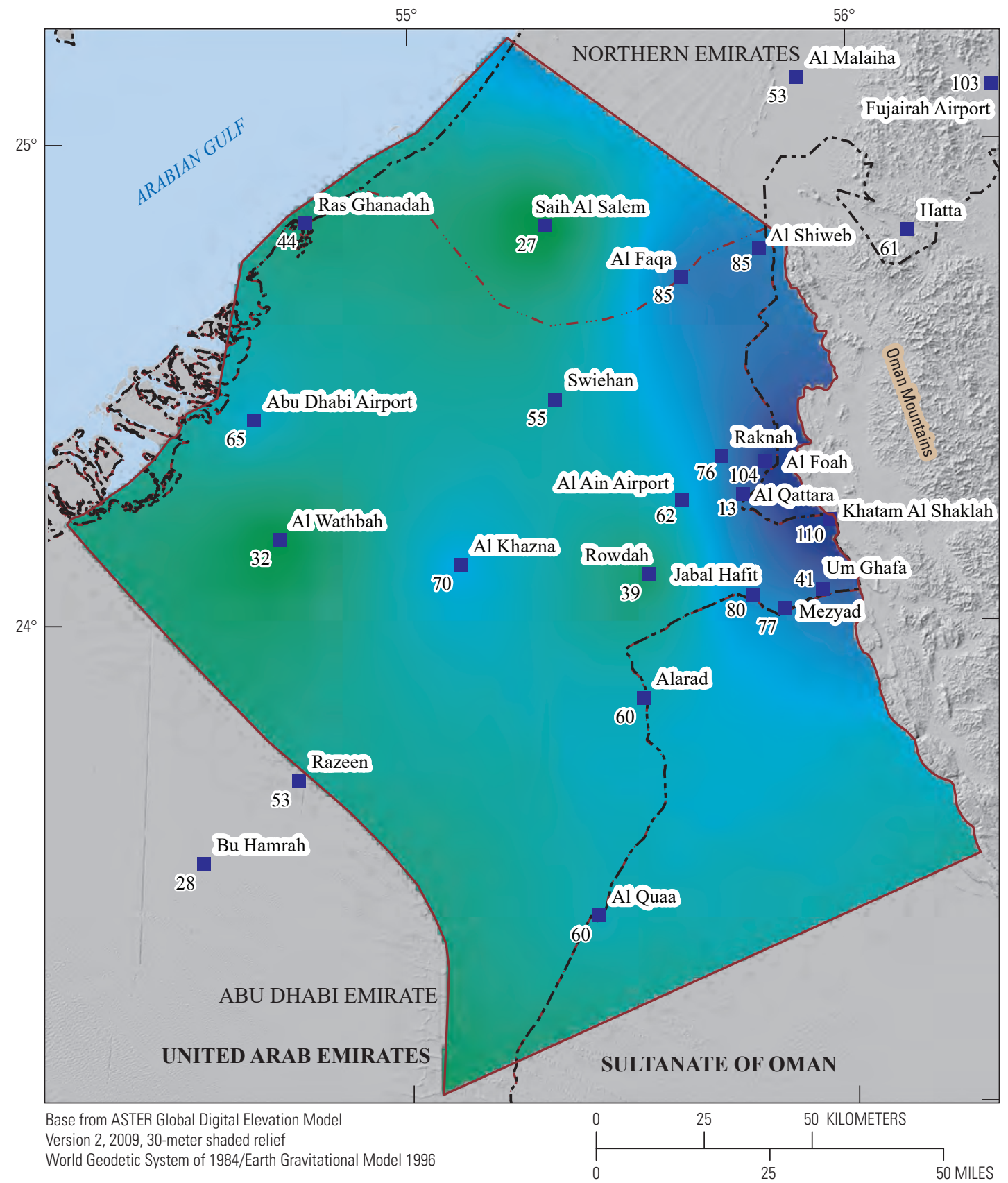

EXPLANATION

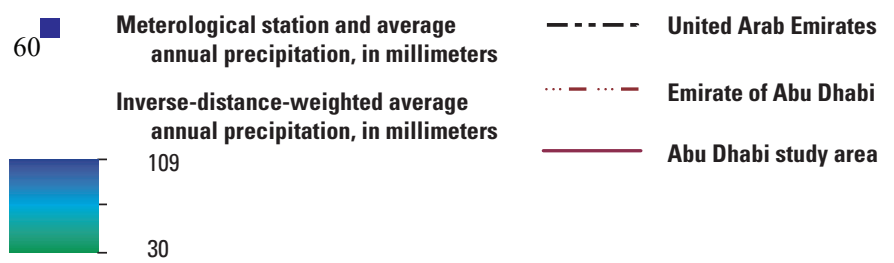

Figure 3. Meteorological stations and mean annual precipitation, based on data from 1982 to 2013, eastern Emirate of Abu Dhabi, United Arab Emirates. 

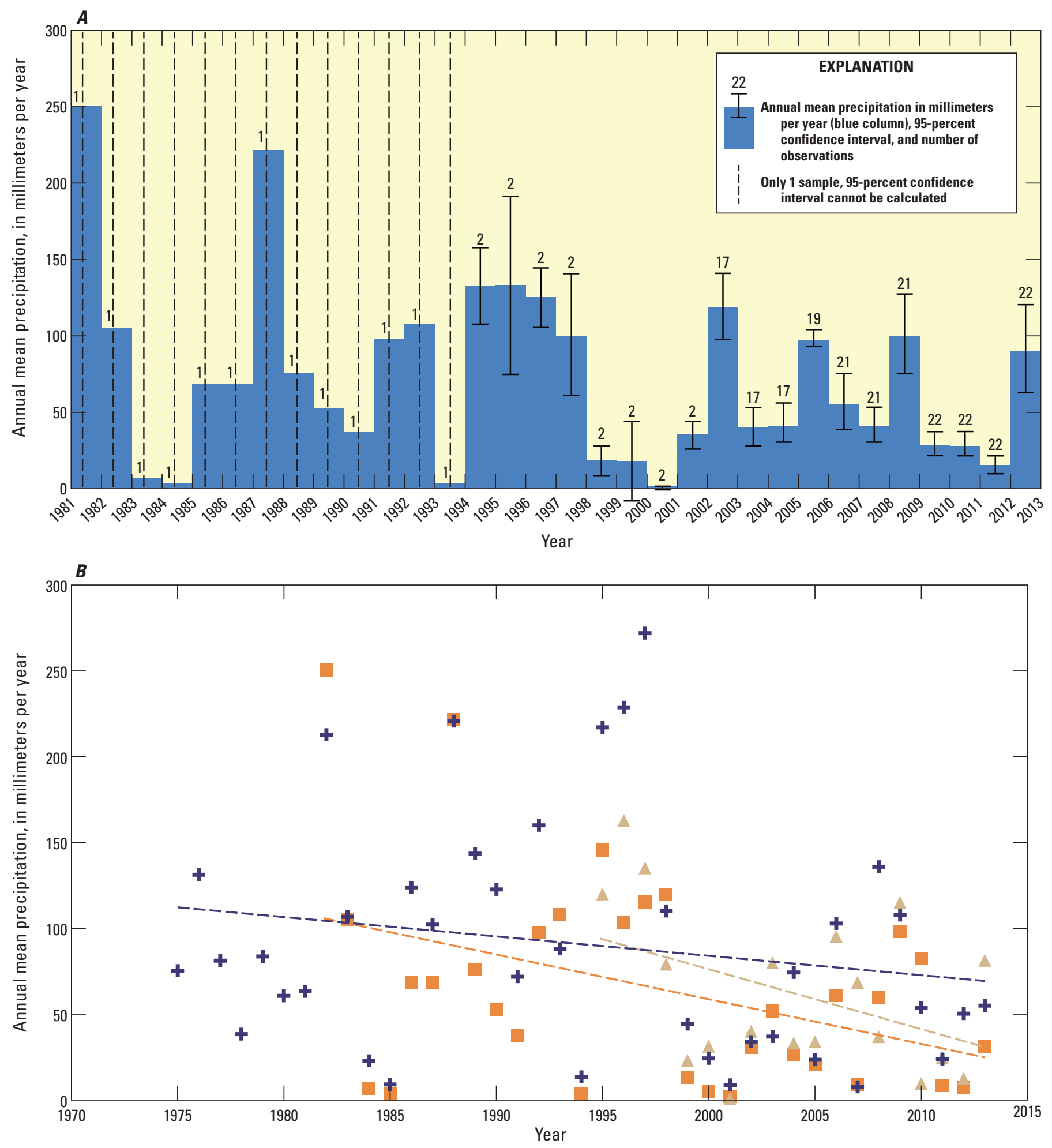

\section{EXPLANATION}

Abu Dhabi International Airport, annual mean precipitation, in millimeters per year, and linear trend

Al Ain International Airport, annual mean precipitation, in millimeters per year, and linear trend

_. Dubai International Airport, annual mean precipitation, in millimeters per year, and linear trend

Figure 4. $A$, Mean annual precipitation from 1982 to 2013 at 23 meteorological stations and $B$, annual total precipitation at 3 stations from 1975 to 2013, eastern Emirate of Abu Dhabi, United Arab Emirates. 


\section{Hydrogeologic Framework}

Compared to the relatively flat-lying geologic formations of western and coastal Abu Dhabi, the geologic structure and hydrostratigraphy of eastern Abu Dhabi are complex. Younger, water-bearing hydrogeologic units in eastern Abu Dhabi have been offset by faults or upthrusted older bedrock units. Moreover, water-bearing units that form principal aquifers in eastern Abu Dhabi are highly folded in most areas; as a result, the extents and thicknesses of water-bearing aquifer units and associated aquifer hydraulic conductivities vary widely across the region (Hutchinson, 2006).

\section{Geology}

The study area encompasses an area of structural transition between uplifted, highly deformed rocks of the Oman Mountains to the east and the buried, flat-lying to gently warped strata near the Arabian Gulf. Bedrock is understood in this study to include low-permeability rock either at the surface or underlying more permeable rock and sediments and is inclusive of crystalline, igneous, and ophiolitic rocks of the Oman Mountains, low-permeability limestone, and indurated sedimentary rock. Rocks exposed in the Oman Mountains east of the Al Ain area have undergone complex, compressive deformation, and a foreland basin containing relatively thick deposits of uppermost Cretaceous to Oligocene limestones and marls was deposited unconformably on deformed ophiolite rocks along the western flank of the Oman Mountains in the Al Ain area (Farrant and others, 2012). The foreland basin deposits, the Simsima, Umm Er Radhuma, Dammam, and Asmari Formations, underwent intense compressional deformation during the late Tertiary that produced the current geologic structure in eastern Abu Dhabi - a series of parallel northwestsoutheast-trending thrust faults, anticlinal ridges, and synclinal troughs adjacent to and west of the Oman Mountains (Farrant and others, 2012).

Younger Tertiary sediments representing both marine and terrestrial depositional environments overlie the more competent limestones and marl bedrock units of the former foreland basin (fig. 5), including (1) interbedded shales, mudstones,

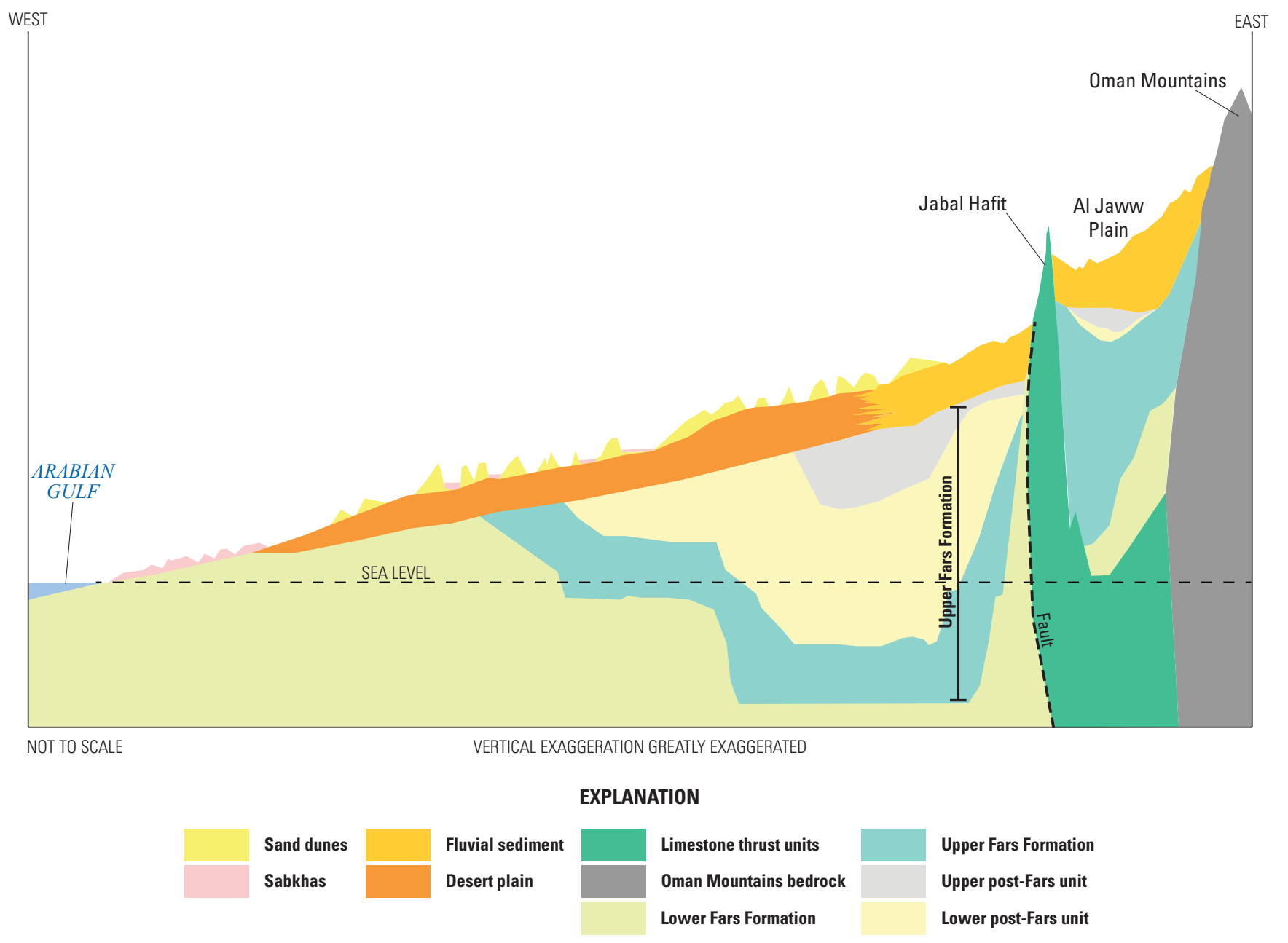

Figure 5. Generalized west-east hydrogeology in Emirate of Abu Dhabi, United Arab Emirates. 
and evaporites of the Miocene Lower Fars (LF) Formation; (2) intercalated marine to nonmarine mudstones, marls, and limestones of the Miocene Upper Fars (UF) Formation; and (3) an overlying Pliocene post-Fars (PF) unit that forms the center of many synclinal troughs and generally consists of poorly consolidated to unconsolidated sand and gravels interbedded with clay (Imes and Clark, 2006). Along the front of the Oman Mountains, and within and north of Al Ain, younger Quaternary alluvium forms a veneer of sediments deposited on an erosional surface of the Fars (Lower, Upper, and post-Fars) and older formations.

Quaternary alluvium along the mountain front in some areas has been intruded by upthrusted wedges of limestone, shale, and mudstone primarily of the Simsima, Dammam, or Asmari Formations. These outcrops typically form small mountain-like features, except at the Jabal Hafit massif, where Dammam and Asmari limestone units rise to more than 1,000 meters above the valley floor.

\section{Hydrogeologic Units and Regional Aquifer System}

Geologic formations with distinct and consistent hydrologic properties such as porosity and permeability (hydraulic conductivity) are referred to as hydrogeologic units (HGUs). Borehole geologic and geophysical logs maintained by NDC and EAD were examined for this study to define regional HGUs and delineate their horizontal and vertical extents in eastern Abu Dhabi (figs. 2 and 5, table 2). Lithologic and geophysical properties estimated from 256 individual borehole logs were used to determine the top and bottom elevations of regional HGUs (Mack and others, 2020). HGU top and bottom elevations were interpolated between borehole locations in eastern Abu Dhabi to provide a three-dimensional framework of the regional aquifer system. Interpolated HGUs and their regional extents, shown in figure 6, were constrained by lithostratigraphic information interpreted from reprocessed industry seismic lines.

The regional aquifer system in eastern Abu Dhabi, referred to in previous studies as the surficial aquifer (Hutchinson, 2006; Imes and Clark, 2006), is composed of the permeable portions of multiple HGUs, including the following: Quaternary eolian sand dune and unconsolidated alluvial deposits, Miocene Upper Fars Formation, Pliocene post-Fars Formation, and Late Cretaceous karstic limestone (Farrant and others, 2012; Imes and Clark, 2006). Limestone units (K, Tle, and Tlo in fig. 6) are spatially limited HGUs that, in some areas, have been deformed, fractured, and uplifted to the shallow subsurface by thrust faulting. The base of the surficial aquifer was determined by identifying the depth at which the borehole lithology and relative permeability changed from more permeable sand, gravel, or conglomerate to less permeable mudstone, clay, claystone, evaporites, or marl. Although clay and (or) marl layers in the Pliocene and Miocene deposits of the post-Fars and Upper Fars HGUs,
Table 2. Descriptions of hydrogeologic units in the eastern Emirate of Abu Dhabi, United Arab Emirates.

\begin{tabular}{|c|c|}
\hline $\begin{array}{c}\text { Hydrogeologic } \\
\text { unit }\end{array}$ & Relative permeability \\
\hline Alluvium & $\begin{array}{l}\text { High-permeability gravel, sand, silt, and eolian } \\
\text { sand, including wadi outwash, gravel plains, } \\
\text { alluvial fans, weathered rock, and Barzaman } \\
\text { Formation }\end{array}$ \\
\hline $\begin{array}{l}\text { Desert plain } \\
\text { sediments }\end{array}$ & $\begin{array}{l}\text { Moderate- to high-permeability desert plain } \\
\text { sediments }\end{array}$ \\
\hline Fluvial sediments & $\begin{array}{l}\text { Moderate- to high-permeability alluvial fan } \\
\text { and fluvial sediments, including wadi } \\
\text { outwash }\end{array}$ \\
\hline Dune & $\begin{array}{l}\text { Moderate- to high-permeability eolian fine } \\
\text { sand at surface }\end{array}$ \\
\hline Sabkhas & $\begin{array}{l}\text { Low permeability, including evaporites and } \\
\text { surface fines }\end{array}$ \\
\hline $\begin{array}{l}\text { Low-conductivity } \\
\text { sediments }\end{array}$ & $\begin{array}{l}\text { Low-permeability sediments, including evapo- } \\
\text { rites, tidal flats, and marshes }\end{array}$ \\
\hline Upper post-Fars & High permeability \\
\hline Lower post-Fars & Moderate permeability \\
\hline Upper Fars & Moderate permeability \\
\hline Lower Fars & Low permeability \\
\hline $\begin{array}{l}\text { Upthrusted sedi- } \\
\text { mentary units }\end{array}$ & $\begin{array}{l}\text { Low-permeability shales, mudstones, and } \\
\text { carbonates. Active in model layers } 1 \text { and } \\
2 \text { where depicted on surface geologic map } \\
\text { (fig. 2) }\end{array}$ \\
\hline Bedrock & $\begin{array}{l}\text { Low-permeability unweathered rock (includes } \\
\text { buried unweathered limestone, igneous, and } \\
\text { metamorphic rocks). Active in small areas } \\
\text { of layers } 1 \text { and } 2 \text { where mapped (fig. } 2 \text { ) }\end{array}$ \\
\hline
\end{tabular}

respectively, might locally confine groundwater, the surficial aquifer in eastern Abu Dhabi contains groundwater that is regionally unconfined (Hutchinson, 2006).

Eolian deposits form complex dunes that blanket much of the study area (fig. 2), except for the interdunal sabkhas and areas of the piedmont plain adjacent to the Oman Mountains, including Al Jaww plain. Eolian dune sands typically are homogeneous, fine-grained, and quartz-dominated in eastern Abu Dhabi; where saturated, these deposits are relatively permeable. The eolian sand HGU primarily was delineated on geophysical logs by large sonic velocities and small densities, relative to underlying alluvial sand and gravel.

Undifferentiated alluvial sand, gravel, silt, and clay of Quaternary age underlie eolian dune sand throughout much of the northern half of the study area, and they form the surface and near-surface deposits in the piedmont plain adjacent to the Oman Mountains. Of relatively high permeability, Quaternary alluvium is a primary water-producing $\mathrm{HGU}$ in eastern $\mathrm{Abu}$ Dhabi (Imes and Clark, 2013). An erosional unconformity separates the Quaternary alluvium from underlying post-Fars and Upper Fars HGUs in the eastern and central parts of the 


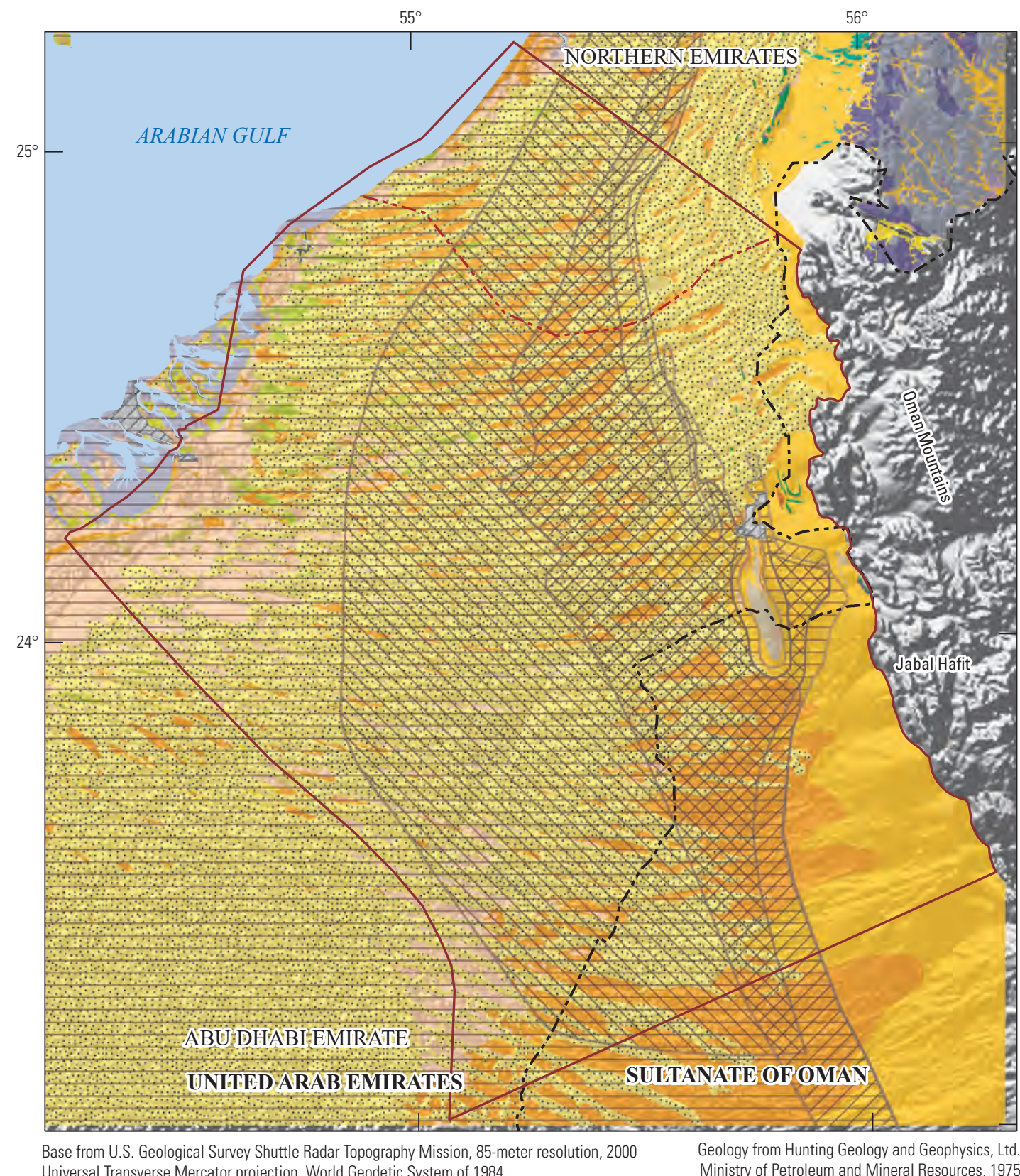

Universal Transverse Mercator projection, World Geodetic System of $1984 \quad$ Ministry of Petroleum and Mineral Resources, 1975

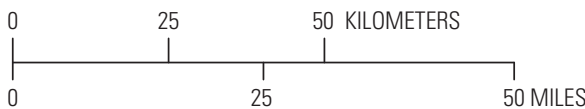

\section{EXPLANATION}

Sand dunes

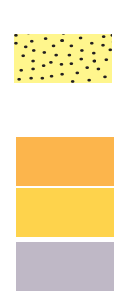

Eolean sand dune $(0 \mathrm{~d})$ Desert and fluvial sediments

Desert plain (0es)

Fluvial sediments $(\mathrm{Og})$

Delta and shoal (Qsh)

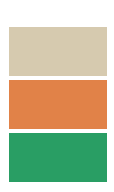

Limestones

Limestone (Tle)

Limestone and marl (Tlo)

Limestone (K)

Sabkhas

Sabkha (0sb)
50 MILES

vaporites and tidal sediments

Evaporites (Tm)

Tidal flat and marsh (Qtf)

Sandstone

Calcareous sandstone $(0 \mathrm{~m})$

Igneous rock

Ultra basic (Sb)
Developed areas

Underlain by post-Fars

Underlain by Upper Fars

Underlain by Lower Fars

Abu Dhabi study area

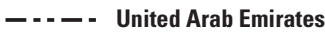

- - - - Emirate of Abu Dhabi

Figure 6. Surficial geology and extent of hydrogeologic units, eastern Emirate of Abu Dhabi, United Arab Emirates. 
study area and the Lower Fars HGU in the western part of the study area (fig. 6). The Quaternary alluvium HGU was primarily delineated on geophysical logs by relatively small values of natural gamma-ray activity, small sonic velocities, and relatively large porosities, which were estimated from gamma-gamma, resistivity, and compensated neutron logs, respectively (Menges and others, 1993).

Primarily on the basis of geophysical properties from geophysical logs maintained by NDC and EAD, and from differing relative permeability (Tawfiq and Nasr, 1997), the post-Fars Formation of Pliocene age was subdivided into two HGUs: a shallower gravelly calcareous sandstone termed the "upper post-Fars" unit and a deeper marl with interbedded sandstone termed the "lower post-Fars" unit. The upper postFars unit is characterized by lower gamma-ray activity and higher resistivity relative to the underlying lower post-Fars unit. Moreover, the lower boundary of the undifferentiated post-Fars unit was identified by an increase in gamma-ray activity (Menges and others, 1993) attributed to an increase in clay (claystone) content of the Upper Fars HGU.

Together with the underlying Upper Fars HGU, the permeability of the sequence from upper to lower post-Fars HGUs and through the Upper Fars HGU generally decreases with increasing depth and corresponding age. Differing permeability reflects changes in the depositional environment, from predominantly a shallow, open marine environment in the Upper Fars HGU to a more continental clastic environment in the post-Fars HGU (fig. 5; Woodward, 1994; Imes and Clark, 2006). The composition of the Upper Fars HGU reflects the changing depositional environment, from gypsiferous mudstone at the base of the unit to claystone with thin intercalated conglomerate in the upper part of the unit. The Upper Fars was primarily delineated on geophysical logs by relatively high gamma-ray activity attributed to a higher fraction of marinedeposited clays than that of other overlying units; the lower boundary of the Upper Fars is characterized by a decrease in gamma-ray activity resulting from an increase in the gypsum content of this unit with depth.

The top of the Lower Fars HGU marks the base of the aquifer system throughout eastern Abu Dhabi, except in some northern areas where the base of the aquifer system is in contact with uplifted limestone units (figs. 5 and 6). The Lower Fars Formation consists of evaporite beds of gypsum and anhydrite interbedded with claystone, mudstone, and minor limestone and dolomite. These low-permeability lithologic units do not typically contribute water to wells, and as a result the Lower Fars Formation is not considered part of the regional aquifer system (Imes and Clark, 2013). The upper boundary of this HGU is based on the highest occurrence of dense anhydrite, identified on geophysical logs by an increase in resistivity and density and by a decrease in gamma-ray activity and neutron porosity.

In some northern areas of the study area, the aquifer system is underlain by a series of dense, upthrusted Cretaceous-Paleogene age limestones and mudstones. Where these units are present at depth and in contact with overlying, more permeable Quaternary alluvium or Fars HGUs, they mark the base of the aquifer system similarly to the Lower Fars HGU. However, in limited areas where limestone units are near or above land surface, they are commonly fractured and karstified, serve as permeable aquifer units contributing water to wells, and are considered part of the regional aquifer system (Imes and Clark, 2006). Groundwater pumping rates from upthrusted limestone units near land surface might be high but are typically not sustainable because the volume of water stored in these fractured formations is limited (Imes and Clark, 2006). Where less permeable mudstone and shale units have been upthrusted near land surface and form regional northwest-southeast trending faults or anticlinal folds, lateral groundwater flow in the regional aquifer system might be locally inhibited or diverted (Woodward, 1994, p. 285-87).

\section{Hydraulic Conductivity}

Hydraulic conductivity describes how readily a porous material will transmit water and typically is determined by aquifer tests, in which groundwater is removed from one well by pumping while water levels in the same well or in surrounding wells are monitored (de Marsily, 1986). When pumping has stopped, the recovery of water levels in wells is also monitored. Water-level measurements made in the pumping well have some utility for determining hydraulic conductivity if no observation wells are available, but more representative conductivity values are obtained when observation wells are also monitored.

Aquifer tests were completed by the GWRP and Environment Agency_Abu Dhabi/Deutsche Gesellschaft für Technische Zusammenarbeit (EAD/GTZ) between 1988 and 1995 and analyzed and presented by Tawfiq and Nasr (1997). Most data from these aquifer tests were analyzed by the CooperJacob method, whereby transmissivity is calculated from the slope of the late-time linear segment of the drawdown data (Cooper and Jacob, 1946). By this method, delayed yield, or gravity drainage, alters the drawdown curve and delays onset of the late-time linear segment needed for accurate transmissivity analysis. Unfortunately, the duration of most of the aquifer tests analyzed by Tawfiq and Nasr (1997) was less than 500 minutes, and, therefore, water-level drawdowns typically were influenced by aquifer-delayed yield; as a result, calculated transmissivity values from this study likely are overestimated.

A study of the hydrogeology of the Al Wagan area (Imes and Tawfiq, 2009) included a detailed analysis of constant-discharge aquifer tests completed in 23 wells. The analysis identified three problems with previous aquifer-test interpretations in the study area: (1) the large well bores of the pumping wells negatively altered the early time drawdown data, (2) gravity drainage of the dewatered aquifer during the tests delayed water-level drawdowns of middle time data, and (3) the tests typically were not long enough to see the linear water-level drawdown of late-time data needed to accurately calculate 
transmissivity. The effect of these problems on calculated transmissivity was assessed by using a set of synthetic drawdown and recovery curves for the pumped wells (Barlow and Moench, 1999) and aquifer properties typical of unconfined conditions encountered in the Al Wagan area. The synthetic drawdown study showed that the gravity-drainage effect ends at about 800 minutes after pumping starts for smaller specific yields $\left(\mathrm{S}_{\mathrm{y}} ; 0.01\right)$, and at about 6,000 minutes after pumping starts for larger $\mathrm{S}_{\mathrm{y}}(0.10)$, both times being longer than the typical 300 minutes to 500 minutes of aquifer-test duration for the studied wells. From the synthetic drawdown curves, it can be inferred that use of the slope within the delayed-yield segment can cause the transmissivity to be overestimated by as much as a factor of about 3 for $\mathrm{S}_{\mathrm{y}}=0.01$ and overestimated by as much as a factor of about 10 for $\mathrm{S}_{\mathrm{y}}=0.10$.

In 2008, the GWRP completed a long-term aquifer test in a well near Swaihan to test the conclusions of the synthetic drawdown study (Imes and Tawfiq, 2009). A Cooper-Jacob straight-line analysis and a best fit Moench solution of the drawdown data from 1 to 6.3 days (after delayed-yield effects) resulted in a transmissivity of 50 meters squared per day. A Cooper-Jacob straight-line analysis of the drawdown data from 66 minutes to about 1 day (during the delayed-yield effects) gave a transmissivity of 124 meters squared per day, or about 2.5 times the correct transmissivity. This test supports the synthetic drawdown analysis and the hypothesis that the durations of most of the previous aquifer tests completed by the GWRP were too short to reliably determine transmissivity.

For this study, aquifer-test data for 163 GWRP wells and $67 \mathrm{EAD} / \mathrm{GTZ}$ wells were reanalyzed to assess the lateral and vertical distribution of hydraulic conductivity in the study area (fig. 7). The aquifer-test data for all 230 wells are archived and maintained at the EAD headquarters in the Emirate of Abu Dhabi and were made available to the USGS for this study. For GWRP wells, drawdown data from 8 of the GWRP wells were obtained from observation wells, and drawdown data

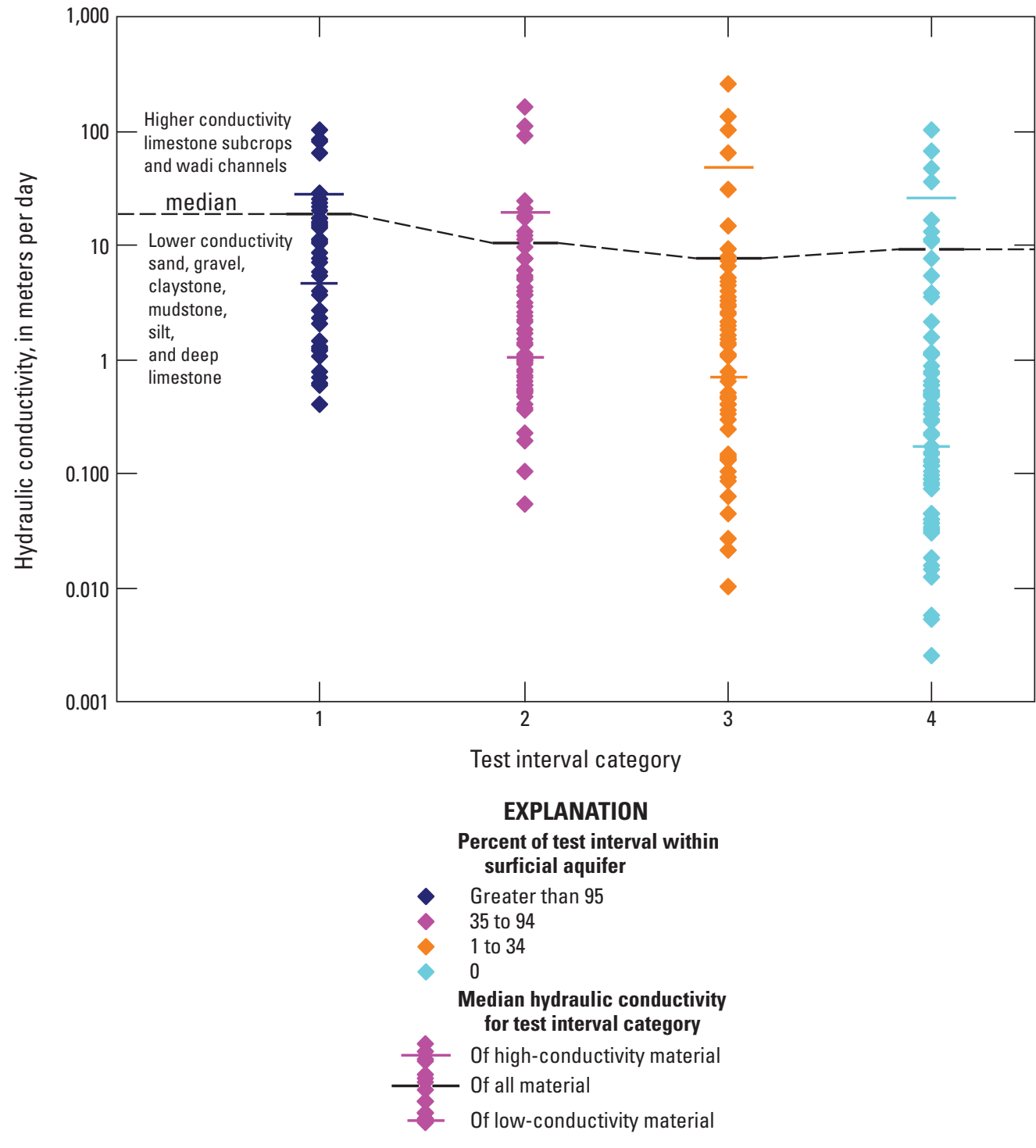

Figure 7. Hydraulic conductivity of surficial aquifer and deep sediments by category, based on percentage of test interval within the surficial aquifer. Horizontal bars represent medians of high-conductivity material, all material in the test interval (connected by the dashed line), and low-conductivity material in each category. Results are from aquifer pumping tests conducted in the study area, eastern Emirate of Abu Dhabi, United Arab Emirates. 
were obtained directly from the remaining 155 GWRP wells. For EAD/GTZ wells, drawdown data from 13 of the EAD/GTZ wells were obtained from observation wells, and data from the remaining 54 wells were obtained from pumping wells. Many of these test wells were in areas where conditions favored delayed yield from gravity drainage, and the test durations for most of these wells were too short to properly define the late-time drawdown slope. The durations of most EAD/GTZ aquifer tests were less than about 1 day, and these data suffer from the same short-duration problem as the data from the GWRP aquifer tests. The insight provided by the previous synthetic drawdown analysis, aquifer-test analyses of data from wells in the Al Wagan area (fig. 8), and the occasional slight slope change at the end of the delayedyield segment of the drawdown curve aided in the curve-fitting analyses and interpretation of all aquifer-test data. Aquifer-test data from 174 of the 230 wells were reanalyzed by using the Moench solution for pumping tests in unconfined aquifers with delayed yield (Moench, 1997). Some aquifer-test data were not amenable to a delayed-yield solution. Data from 45 wells were analyzed by using the Moench solution for pumping tests in leaky aquifers (Moench, 1985). The test intervals of these wells usually intersected sequences of alternating sediments of higher and lower permeability, such as silts and mudstones, and sampled deeper sediments beneath the surficial aquifer. Data from the remaining 11 wells were analyzed by using the Papadopoulos-Cooper solution for pumping tests in confined aquifers (Papadopoulos and Cooper, 1967).

Each of the 230 hydraulic conductivity values was assigned to one of four categories based on the percentage of the pumping well's test interval that was open in the surficial aquifer. The percentage of test interval in the surficial aquifer was used as an indicator of the degree to which the test results represent surficial aquifer sediment (fig. 8). The four categories were

- Category 1: good representation-greater than 95 percent of the test interval is within the surficial aquifer,

- Category 2: moderate representation - between 35 and 95 percent of the test interval is within the surficial aquifer,

- Category 3: poor representation-between 1 and 34 percent of the test interval is within the surficial aquifer, and

- Category 4: no representation-none ( 0 percent) of the test interval is within the surficial aquifer.

For the 39 wells in category 1 , hydraulic conductivity values (fig. $8 A$ ) ranged from 0.4 meter per day $(\mathrm{m} / \mathrm{d})$ to $101 \mathrm{~m} / \mathrm{d}$. In this category, 8 of the 9 largest conductivity values (greater than $21 \mathrm{~m} / \mathrm{d}$ ) are associated with wells that are likely to be open to paleochannels or recent wadi channels composed of coarse gravel or conglomerate that extend westward from gaps in the front range of the western slopes of the Oman Mountains. One of the nine wells is open to limestone near Al Hayer (fig. 8A). The median of the 9 largest conductivity values is $28 \mathrm{~m} / \mathrm{d}$, and the median of the 30 remaining conductivity values is $4.6 \mathrm{~m} / \mathrm{d}$ (fig. 7).

For the 60 wells in category 2, hydraulic conductivity values ranged from 0.1 to $159 \mathrm{~m} / \mathrm{d}$. Six of the 10 largest conductivity values (greater than $10 \mathrm{~m} / \mathrm{d}$ ) in this category are associated with wells that are likely to be open to paleochannels or recent wadi channels. Two of these wells are open to limestone, and two are open to gravel and conglomerate possibly associated with ancient wadis in the Al Jabeeb area (fig. $8 B$ ). The median of the 10 largest conductivity values is $19 \mathrm{~m} / \mathrm{d}$, and the median of the 50 remaining conductivity values is $1 \mathrm{~m} / \mathrm{d}$ (fig. $8 B$ ).

For the 59 wells in category 3 , hydraulic conductivity values ranged from less than 0.1 to $256 \mathrm{~m} / \mathrm{d}$ (fig. $8 C$ ). Three of the 8 largest conductivity values (greater than $8 \mathrm{~m} / \mathrm{d}$ ) in this category are associated with wells that probably are open to paleo-wadis, and 5 are from wells open to limestone near bedrock outcrops. The median of the 8 largest conductivity values is $48 \mathrm{~m} / \mathrm{d}$, and the median of the 51 remaining conductivity values is $0.7 \mathrm{~m} / \mathrm{d}$.

For the 72 wells in category 4 , hydraulic conductivity values ranged from less than 0.1 to $102 \mathrm{~m} / \mathrm{d}$ (fig. $8 D$ ). One of the 8 largest conductivity values (greater than $10 \mathrm{~m} / \mathrm{d}$ ) in this category is from a well open to a wadi channel, 2 are from wells open to gravel or conglomerate, and 5 are from wells open to limestone near bedrock outcrops. The median of the 8 largest conductivity values is $26 \mathrm{~m} / \mathrm{d}$, and the median of the 64 remaining conductivity values is $0.2 \mathrm{~m} / \mathrm{d}$ (fig. $8 D$ ).

Most of the hydraulic conductivities in each category (77, 83,86 , and 88 percent for categories $1-4$, respectively) are less than about $10 \mathrm{~m} /$ day (figs. $8 A-D$ ). Larger but less common hydraulic conductivity values in each category are generally associated with the site-specific drilling of test wells in known or suspected wadi channels and potentially weathered shallow limestone for the specific purpose of locating high-yielding sediment and rock. In general, high conductivities (greater than $10 \mathrm{~m} / \mathrm{d}$ ) are found in the easternmost areas of the study area adjacent to the Oman Mountains. Excluding these large conductivity values from the dataset, category 1 values range about 2 orders of magnitude, category 2 values range about 2.5 orders of magnitude, category 3 values range about 3 orders of magnitude, and category 4 values range about 3.5 orders of magnitude (figs. $8 A-D$ ). The lower hydraulic conductivity values of category 4 are typically associated with relatively deeply buried and less permeable claystones and mudstones that underlie the surficial aquifer. Median hydraulic conductivity values for category 4 are about 0.5 order of magnitude lower than values for category 3 . 


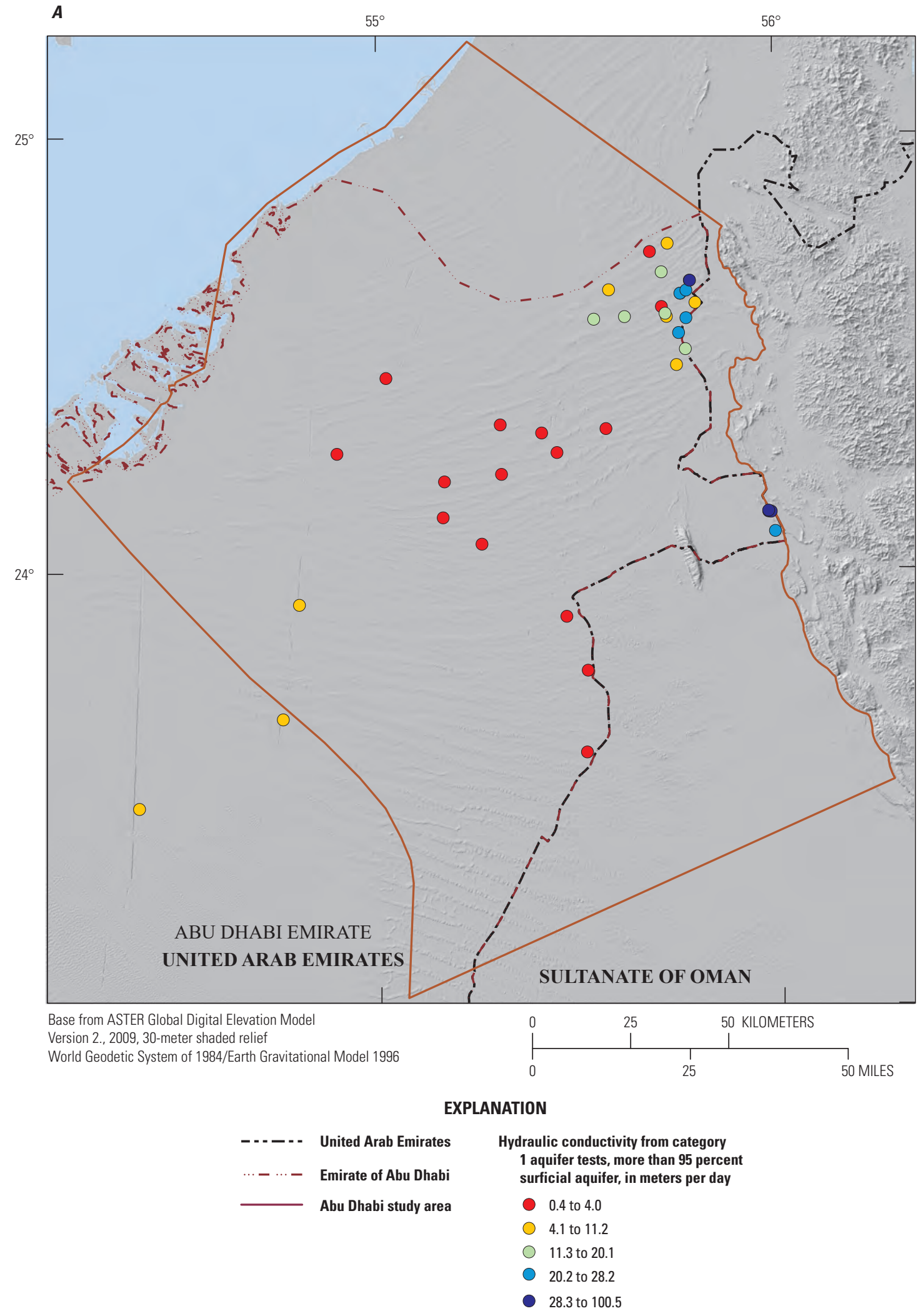

Figure 8. Median hydraulic conductivity values of surficial and deep aquifer sediments, based on percentage of test interval, in the surficial aquifer in $A$, category $1, B$, category $2, C$, category 3 , and $D$, category 4 , for the eastern Emirate of Abu Dhabi, United Arab Emirates. 


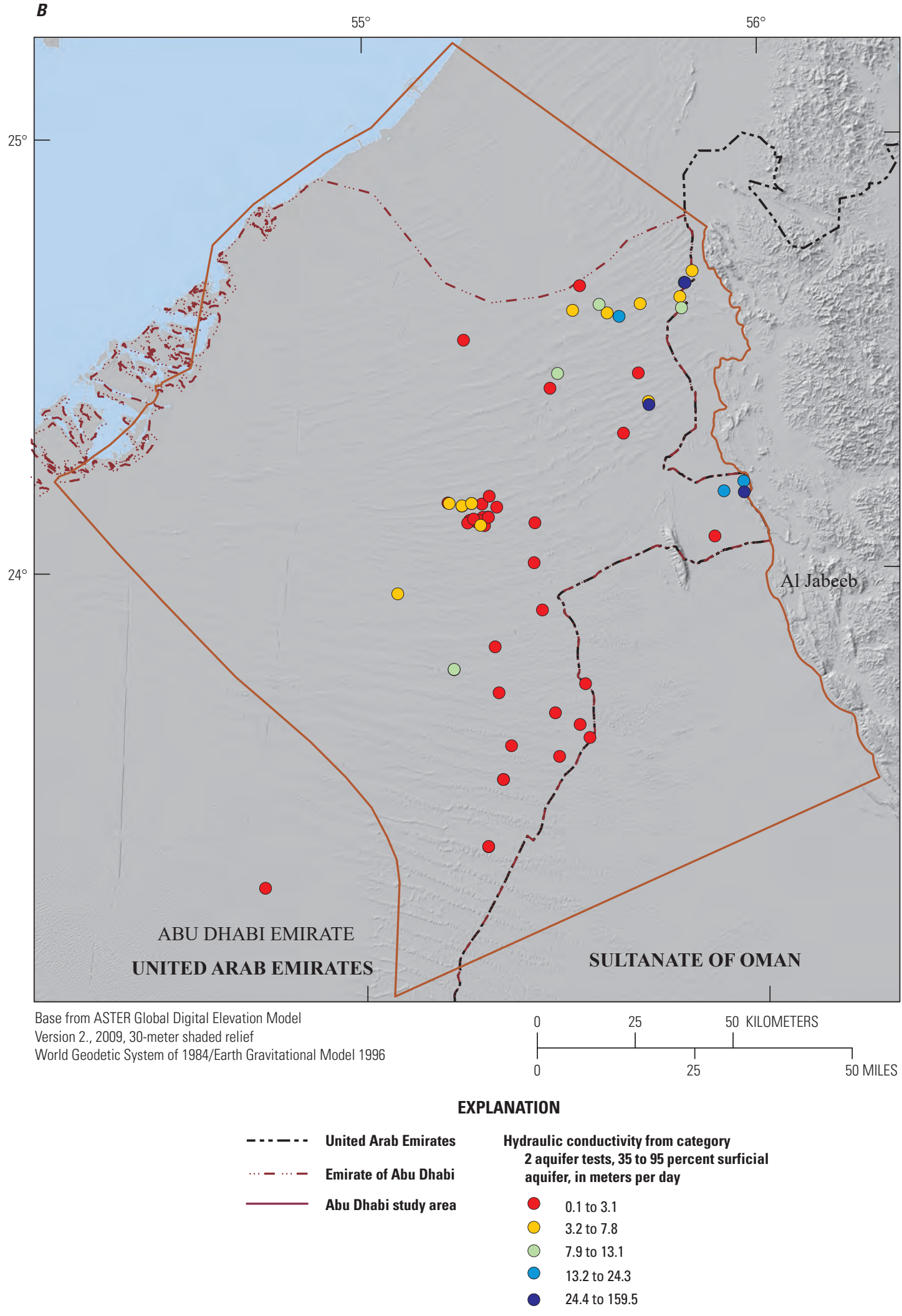

Figure 8. Median hydraulic conductivity values of surficial and deep aquifer sediments, based on percentage of test interval, in the surficial aquifer in $A$, category $1, B$, category $2, C$, category 3 , and $D$, category 4 , for the eastern Emirate of Abu Dhabi, United Arab Emirates.-Continued 


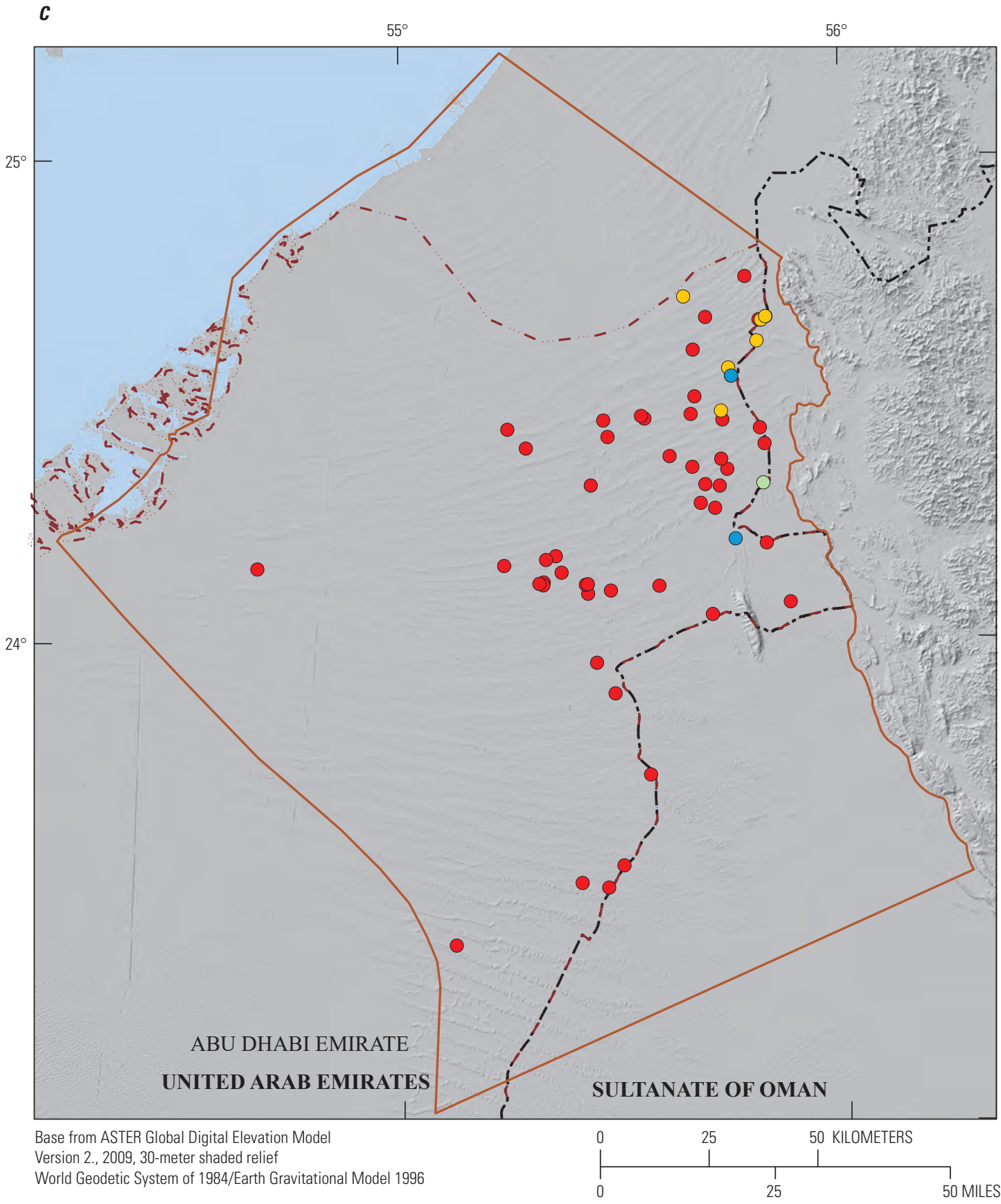

\section{EXPLANATION}
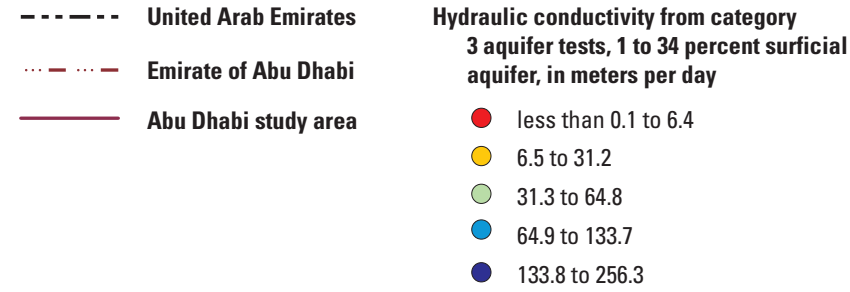

133.8 to 256.3

Figure 8. Median hydraulic conductivity values of surficial and deep aquifer sediments, based on percentage of test interval, in the surficial aquifer in $A$, category $1, B$, category $2, C$, category 3 , and $D$, category 4 , for the eastern Emirate of Abu Dhabi, United Arab Emirates. - Continued 


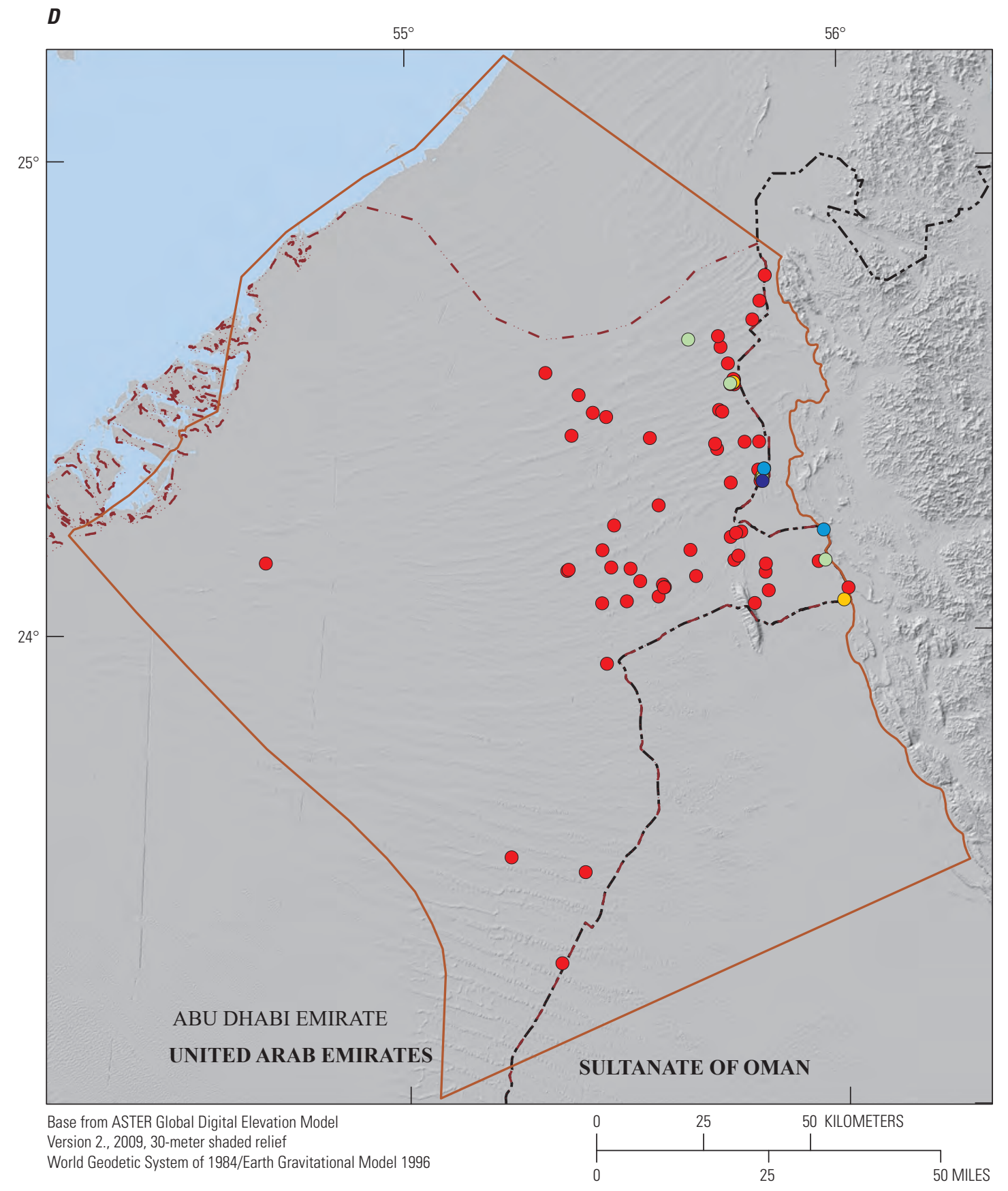

\section{EXPLANATION}

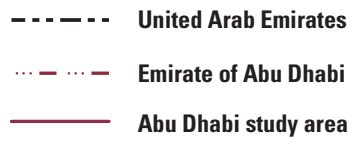
Hydraulic conductivity from category 4 aquifer tests, no surficial aquifer, in meters per day
less than 0.0 to 2.1
2.2 to 7.5
7.6 to 16.7
- 16.8 to 66.7
- 66.8 to 101.9

Figure 8. Median hydraulic conductivity values of surficial and deep aquifer sediments, based on percentage of test interval, in the surficial aquifer in $A$, category $1, B$, category $2, C$, category 3 , and $D$, category 4 , for the eastern Emirate of Abu Dhabi, United Arab Emirates. - Continued 


\section{Predevelopment Groundwater Conditions}

Population in the United Arab Emirates grew from about 70,000 in 1950 to 8.44 million in 2010 (United Nations, 2012), whereas the population of Abu Dhabi Emirate increased from 0.21 million in 1975 to 1.34 million in 2005 (Statistics Center Abu Dhabi, 2010). The groundwater flow system in eastern Abu Dhabi is currently (2016) affected by groundwater withdrawals for agricultural irrigation and by municipal use and associated recharge of wastewater. However, before 1980, groundwater withdrawals would have been few and comparatively small (Hutchinson, 2006).

Predevelopment conditions, for the purposes of this study, are defined as the conditions prior to 1980. Development in UAE is related to the discovery of oil resources in the 1960s. Development began to accelerate in the 1980s and led to an associated growth in groundwater use. Predevelopment groundwater conditions in Abu Dhabi reflected the sparse population of the Emirate and the correspondingly light water usage. During the predevelopment period, groundwater withdrawals were likely from dug wells equipped with hand pumps and from aflaj, both of which withdraw groundwater at low rates and are discussed in more detail in the "Discharge and Water Use" section. With limited population and groundwater pumping, predevelopment conditions prior to 1980 represent a natural, steady-state groundwater flow system.

\section{Recharge}

Natural recharge to the aquifer system in the eastern region occurs from rain that falls on the western flank of the Oman Mountains and possibly from rainfall on the piedmont plain to the west of the mountains (fig. 9). Rainfall in the Oman Mountains recharges aquifers in the eastern region by periodic surface-water flood flow and by groundwater inflow in stream channels and along the mountain front. Direct infiltration of rainfall on the piedmont and interdunal areas of the eastern region also may be contributing to aquifer recharge. In the arid climate of the UAE, annual potential evapotranspiration is substantially greater than rainfall, and most rain that infiltrates is evaporated or transpired from the shallow

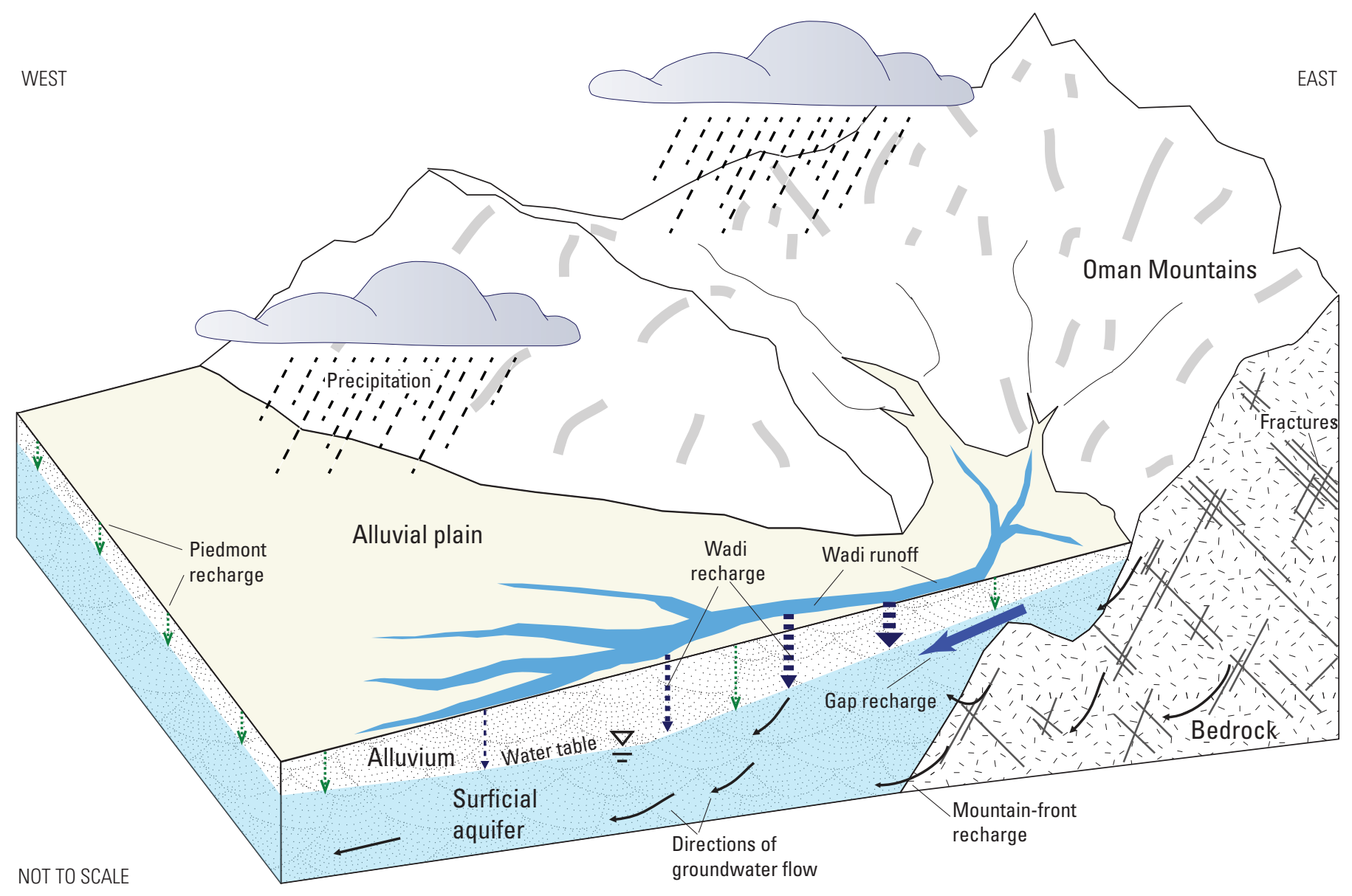

Figure 9. Mountain-front recharge and lateral inflow from the Oman Mountains to the aquifer, eastern Emirate of Abu Dhabi, United Arab Emirates. 
subsurface (fig. 10). However, past studies have suggested that during infrequent but intense storms, infiltration rates can exceed evaporation rates so that some recharge to the aquifer occurs in the piedmont plain to the west of the mountains (Osterkamp and others, 1995; Sherif and others, 2014).

In this study, four primary recharge processes were evaluated on the basis of Osterkamp and others (1995), which currently (2016) is the only peer-reviewed study to describe multiple recharge processes in sufficient detail to estimate total groundwater recharge for the eastern region of the Emirate. The four recharge processes (fig. 9) are the following:

1. Piedmont recharge - infiltration of rainfall from intense storms on the piedmont plain and interdunal areas and infiltration of rainfall in the Oman Mountains (fig. 9),

2. Wadi recharge-infiltration of surface-water runoff in wadi (dry riverbed or wash) channels. Storm-generated wadi runoff occurs through erosional canyons or "gaps" along the front of the Oman Mountains and infiltrates into channel deposits on the piedmont plain (fig. 11) a few to tens of kilometers from the mountains,

3. Gap recharge - groundwater flow through wadi-channel deposits where wadis exit mountain gaps along the boundary of the piedmont plain and mountain front at the study area boundary, and

4. Mountain-front recharge — groundwater flow through fractured bedrock formations of the Oman Mountains that discharges to the aquifer along the mountain front (fig. 11) between mountain gaps.
Piedmont, wadi, gap, and mountain-front recharge (table 3) were estimated by Osterkamp and others (1995) using two models: a numerical runoff-infiltration model (Lane, 1982) and a water-balance model (Knisel, 1980). The runoff-infiltration model was applied to estimate wadi and gap recharge from the 17 hydrologic basins draining the Oman Mountains. The basins draining to study area wadis are shown in figure 11 and described in detail in Osterkamp and others (1995). This model was based, in part, on the amount of recharge that occurs from an "index-storm event" equal to the mean of the annual single-storm precipitation maxima. For the piedmont plain, the index-storm event equaled $31 \mathrm{~mm} / \mathrm{yr}$, a value based on a 20-year record of measured precipitation in Al Ain from 1971 to 1990. For the Oman Mountains, index-storms were estimated for each drainage basin (fig. 12; Osterkamp and others, 1995) by proportionally adjusting the piedmont plain index-storm event. Adjustments were based on drainage basin area and estimated mean annual precipitation for each basin. The mean index-storm event for the 17 drainage basins in the Oman Mountains examined by Osterkamp and others (1995) equaled $57 \mathrm{~mm} / \mathrm{yr}$. Wadi recharge (transmission loss below mountain gaps in table 3) was estimated by Osterkamp and others (1995) at $1.3 \mathrm{~mm} / \mathrm{yr}$ (3.9 million cubic meters per year $\left[\mathrm{Mm}^{3} / \mathrm{yr}\right]$ ), and gap recharge to the piedmont plain at mountain gaps was estimated at $14.7 \mathrm{~mm} / \mathrm{yr}\left(42.2 \mathrm{Mm}^{3} / \mathrm{yr}\right)$. This recharge process is assumed to be consistent at four additional wadis along the Oman Mountains in the study area (fig. 11), immediately south of those examined by Osterkamp and others (1995) (south of the inset area in fig. 11).

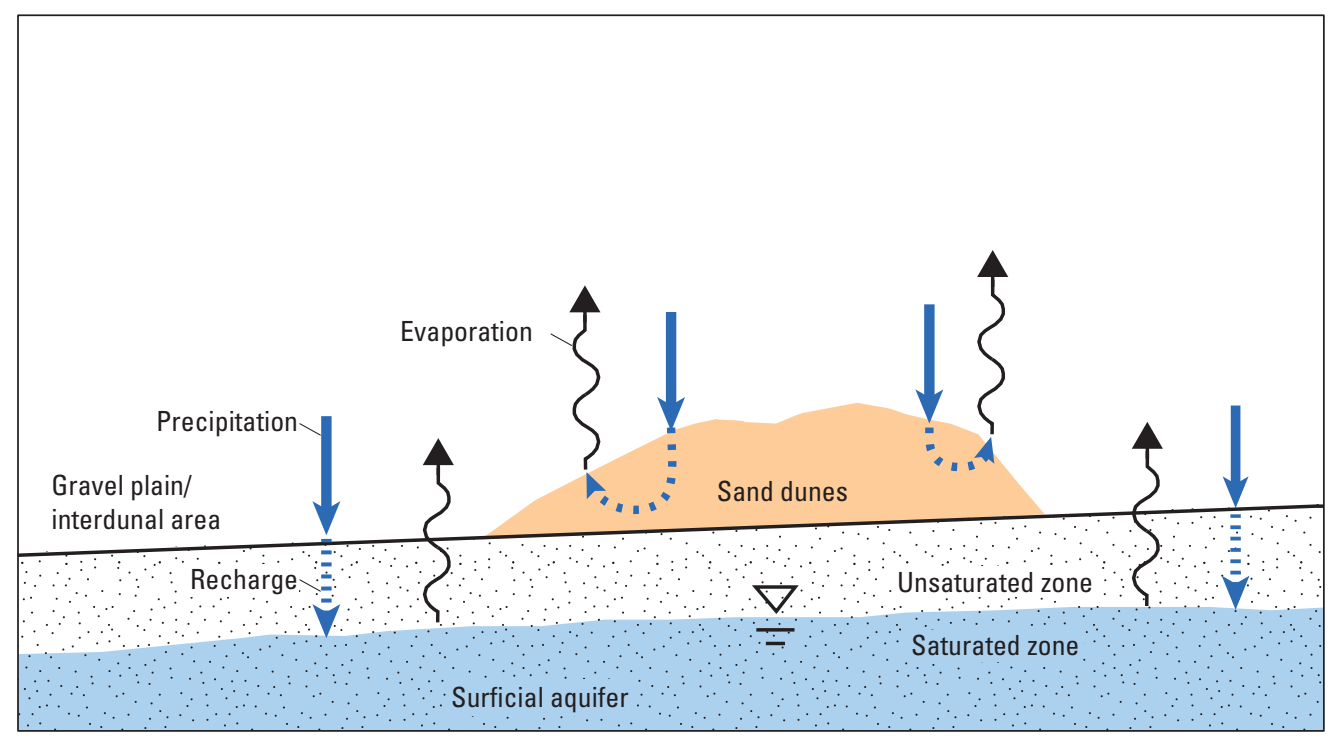

NOT TO SCALE
Figure 10. A generalized conceptual model of precipitation, recharge, and evapotranspiration on sand dunes and desert plains. 


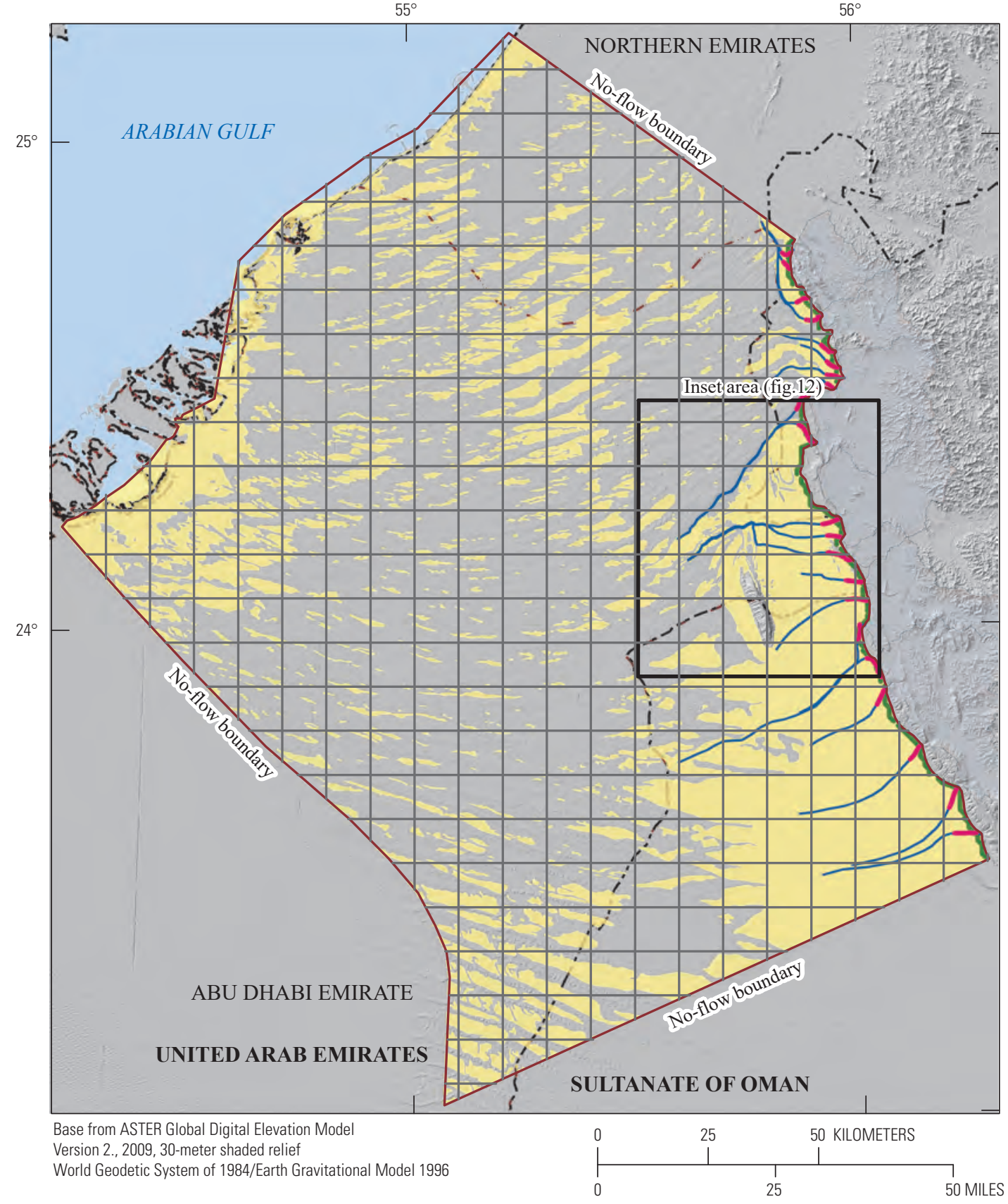

EXPLANATION

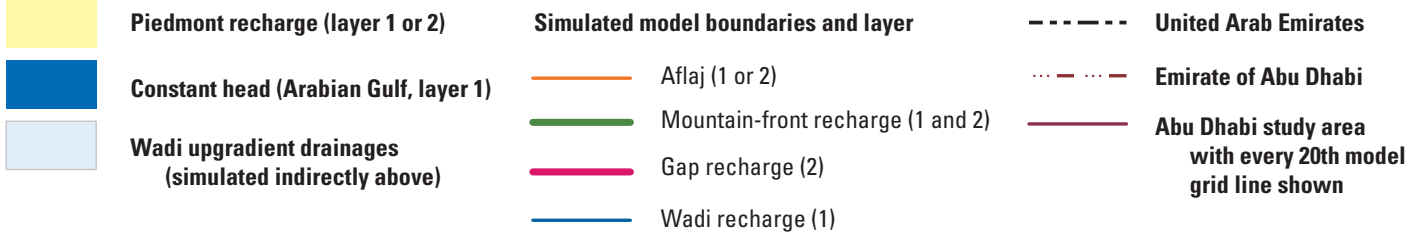

Figure 11. Model boundary conditions and grid spacing, eastern Emirate of Abu Dhabi, United Arab Emirates. 
Table 3. Summary of estimated annual volumetric and linear rates of natural aquifer recharge, and recharge as a percentage of precipitation, by recharge component, modified from Osterkamp and others (1995).

[Seq. no., sequence number; $\mathrm{Mm}^{3} / \mathrm{yr}$, million cubic meters per year; $\mathrm{mm} / \mathrm{yr}$, millimeter per year; $\mathrm{mm}$, millimeter; $\mathrm{km}^{2}$, square kilometer; --, not applicable or not calculated]

\begin{tabular}{|c|c|c|c|c|c|c|c|}
\hline \multirow[b]{2}{*}{$\begin{array}{l}\text { Seq. } \\
\text { no. }\end{array}$} & \multirow[b]{2}{*}{$\begin{array}{l}\text { Recharge component, } \\
\text { abbreviated descrip- } \\
\text { tion, from Osterkamp } \\
\text { and others (1995) }\end{array}$} & \multirow[b]{2}{*}{$\begin{array}{l}\text { Recharge component } \\
\text { acronym and table } \\
\text { number, from Oster- } \\
\text { kamp and others (1995) }\end{array}$} & \multirow[b]{2}{*}{ Recharge component, detailed description } & \multicolumn{4}{|c|}{ Estimated recharge magnitude } \\
\hline & & & & $\begin{array}{l}\text { Volumetric } \\
\text { rate } \\
\left(\mathrm{Mm}^{3} / \mathrm{yr}\right)\end{array}$ & $\begin{array}{l}\text { Linear rate } \\
(\mathrm{mm} / \mathrm{yr})^{\mathrm{a}}\end{array}$ & $\begin{array}{l}\text { Percent of } \\
\text { index- } \\
\text { storm } \\
\text { event }\end{array}$ & $\begin{array}{c}\text { Percent } \\
\text { of mean } \\
\text { annual } \\
\text { precipita- } \\
\text { tion }\end{array}$ \\
\hline \multicolumn{8}{|c|}{ Precipitation components } \\
\hline 1 & $\begin{array}{l}\text { Mean annual } \\
\text { precipitation }\end{array}$ & MAPR, table 1 & $\begin{array}{l}\text { Estimated mean annual precipitation for (1) Oman Mountains } \\
\text { drainages, (2) piedmont plain, and (3) combined Oman Moun- } \\
\text { tains-piedmont plain area, equal to about 156, 100, and } 130 \mathrm{~mm} \text {, } \\
\text { respectively. Data presented in Osterkamp and others (1995) } \\
\text { from } 20 \text { years of precipitation data collected in Al Ain from } \\
\text { 1971-90, and from Halcrow and Partners (1969a, b, and c). }\end{array}$ & -- & $\begin{array}{l}\text { (1) } 156 \mathrm{~mm} \\
\text { (2) } 100 \mathrm{~mm}^{\mathrm{b}} \\
\text { (3) } 130 \mathrm{~mm}\end{array}$ & -- & 100.0 \\
\hline 2 & Index-storm event & RNFL, tables 1 and 2 & $\begin{array}{l}\text { Assumed to equal the mean annual maximum precipitation from } \\
\text { a single storm event of a magnitude equivalent to a recurrence } \\
\text { interval of } 2.33 \text { years. The index-storm event is used as a surro- } \\
\text { gate for higher intensity storms that may result in recharge on the } \\
\text { piedmont plain or to drainage basins in the Oman Mountains. For } \\
\text { Al Ain and surrounding piedmont plain, the index-storm event } \\
\text { is equal to } 31 \mathrm{~mm} \text { based on a } 20 \text {-year record of precipitation at } \\
\text { Al Ain (1971-90). For all Oman Mountains drainage basins, the } \\
\text { average index-storm event is equal to } 57.1 \mathrm{~mm} \text {. The index-storm } \\
\text { event was estimated for each Oman Mountains drainage basin by } \\
\text { proportionally increasing or decreasing the Al Ain index-storm } \\
\text { event based on drainage basin precipitation and area. }\end{array}$ & 164.1 & 57.1 & 100.0 & -- \\
\hline \multicolumn{8}{|c|}{ Recharge components-Oman Mountains } \\
\hline 3 & $\begin{array}{l}\text { Transmission loss } \\
\text { above mountain gaps }\end{array}$ & TRLS-AG, ${ }^{\mathrm{c}}$ table 2 & $\begin{array}{l}\text { Estimated subsurface inflow to piedmont plain through wadi chan- } \\
\text { nel deposits at mountain gaps }\end{array}$ & 42.2 & 14.7 & 25.7 & 9.4 \\
\hline 4 & $\begin{array}{l}\text { Inter-wadi recharge } \\
\text { above mountain gaps }\end{array}$ & IWRC, table 2 & $\begin{array}{l}\text { Estimated intergap mountain-front recharge to piedmont plane from } \\
\text { rainfall infiltration into fractured bedrock of Oman Mountains } \\
\text { within drainages above mountain gaps }\end{array}$ & 5.6 & 2.0 & 3.4 & 1.3 \\
\hline 5 & $\begin{array}{l}\text { Transmission loss } \\
\text { below mountain gaps }\end{array}$ & TRLS-BG, ${ }^{\mathrm{c}}$ table 2 & $\begin{array}{l}\text { Estimated surface infiltration into wadi channel deposits of pied- } \\
\text { mont plain from storm runoff below mountain gaps }\end{array}$ & 3.9 & 1.3 & 2.4 & 0.9 \\
\hline \multicolumn{8}{|c|}{ Recharge component-Piedmont plain } \\
\hline 6 & $\begin{array}{l}\text { Inter-wadi recharge } \\
\text { below mountain gaps }\end{array}$ & $\begin{array}{l}\text { Recharge below gaps, } \\
\text { table } 4\end{array}$ & $\begin{array}{l}\text { Estimated inter-wadi recharge to piedmont plane and interdunal } \\
\text { areas from infiltration of precipitation }\end{array}$ & 3.6 & 1.1 & $3.4^{\mathrm{e}}$ & 1.1 \\
\hline
\end{tabular}


Table 3. Summary of estimated annual volumetric and linear rates of natural aquifer recharge, and recharge as a percentage of precipitation, by recharge component, modified from Osterkamp and others (1995).—Continued

[Seq. no., sequence number; $\mathrm{Mm}^{3} / \mathrm{yr}$, million cubic meters per year; $\mathrm{mm} / \mathrm{yr}$, millimeter per year; $\mathrm{mm}$, millimeter; $\mathrm{km}^{2}$, square kilometer; --, not applicable or not calculated]

\begin{tabular}{|c|c|c|c|c|c|c|c|}
\hline \multirow[b]{2}{*}{$\begin{array}{l}\text { Seq. } \\
\text { no. }\end{array}$} & \multirow[b]{2}{*}{$\begin{array}{l}\text { Recharge component, } \\
\text { abbreviated descrip- } \\
\text { tion, from Osterkamp } \\
\text { and others (1995) }\end{array}$} & \multirow[b]{2}{*}{$\begin{array}{l}\text { Recharge component } \\
\text { acronym and table } \\
\text { number, from Oster- } \\
\text { kamp and others (1995) }\end{array}$} & \multirow[b]{2}{*}{ Recharge component, detailed description } & \multicolumn{4}{|c|}{ Estimated recharge magnitude } \\
\hline & & & & $\begin{array}{l}\text { Volumetric } \\
\text { rate } \\
\left(\mathrm{Mm}^{3} / \mathrm{yr}\right)\end{array}$ & $\begin{array}{l}\text { Linear rate } \\
(\mathrm{mm} / \mathrm{yr})^{\mathrm{a}}\end{array}$ & $\begin{array}{l}\text { Percent of } \\
\text { index- } \\
\text { storm } \\
\text { event }\end{array}$ & $\begin{array}{l}\text { Percent } \\
\text { of mean } \\
\text { annual } \\
\text { precipita- } \\
\text { tion }\end{array}$ \\
\hline \multicolumn{8}{|c|}{ Recharge summary } \\
\hline 7 & $\begin{array}{l}\text { Total Oman Mountains } \\
\text { average annual } \\
\text { recharge }\end{array}$ & $\begin{array}{l}\text { Recharge above gaps }{ }^{\mathrm{f}} \\
\text { (TRLS-AG + } \\
\text { TRLS-BG + IWRC), } \\
\text { table } 4\end{array}$ & $\begin{array}{l}\text { Total estimated average annual recharge from precipitation in } \\
\text { Oman Mountains to piedmont plain by (1) subsurface inflow at } \\
\text { mountain gaps, (2) mountain-front recharge through fractured } \\
\text { bedrock, and (3) surface infiltration in wadi channels below } \\
\text { mountain gaps }\end{array}$ & 51.7 & $18.0^{\mathrm{g}}$ & 31.5 & 11.5 \\
\hline 8 & $\begin{array}{l}\text { Total Oman Mountains } \\
\text { and piedmont plane } \\
\text { average annual } \\
\text { recharge }\end{array}$ & $\begin{array}{l}\text { Total recharge } \\
\text { (TRLS-AG }+ \\
\text { TRLS-BG + IWRC } \\
\text { + Recharge below } \\
\text { gaps), table } 4\end{array}$ & $\begin{array}{l}\text { Total estimated average annual recharge to Oman Mountains } \\
\text { (components 3-5) and rainfall infiltration on piedmont plane } \\
\text { (component } 6 \text { ) }\end{array}$ & 55.3 & $8.8^{\mathrm{h}}$ & -- & 6.8 \\
\hline \multicolumn{8}{|c|}{ Evapotranspiration } \\
\hline 9 & $\begin{array}{c}\text { Evapotranspiration- } \\
\text { Oman Mountains }\end{array}$ & Not applicable & $\begin{array}{l}\text { Evaporation from bare-soil surface or evapotranspiration from } \\
\text { sparsely vegetated surface. Estimated for Oman Mountains area } \\
\text { as a residual by subtracting estimated total recharge from mean } \\
\text { annual precipitation (about } 156 \mathrm{~mm} \text { ). Evapotranspiration esti- } \\
\text { mate not described in Osterkamp and others (1995). }\end{array}$ & -- & 138.0 & -- & 88.5 \\
\hline 10 & $\begin{array}{l}\text { Evapotranspiration- } \\
\text { piedmont plain }\end{array}$ & Not applicable & $\begin{array}{l}\text { Evaporation from bare-soil surface or evapotranspiration from } \\
\text { sparsely vegetated surface. Estimated for piedmont plain area as } \\
\text { a residual by subtracting estimated total recharge from mean an- } \\
\text { nual precipitation (about } 100 \mathrm{~mm} \text { ). Evapotranspiration estimate } \\
\text { not described in Osterkamp and others (1995). }\end{array}$ & -- & 98.9 & -- & 98.9 \\
\hline
\end{tabular}

${ }^{a}$ Calculated by dividing volumetric rate by total mountain basin area or piedmont plain area equal to 2,871.4 and 3,418.9 $\mathrm{km}^{2}$, respectively. Area of mountain basin drainage from table 2 in Osterkamp and others (1995); piedmont drainage area equals difference between areas shown in table 2 and table 4 in Osterkamp and others (1995).

b20-year average precipitation for Al Ain station (1971-90) reported as $99 \mathrm{~mm}$ in Osterkamp and others (1995); a value of $100 \mathrm{~mm}$ was arbitrarily chosen for this report to represent the entire piedmont plain.

${ }^{\mathrm{c}}$ Column headers for TRLS (AG) and TRLS (BG) are reversed in table 2 of original Osterkamp and others (1995) report. Correct average-annual recharge volume for TRLS (AG) is 42.193 Mm³/yr and for TRLS (BG) is $3.874 \mathrm{Mm}^{3} / \mathrm{yr}$ (Waite Osterkamp, oral commun., 2015).

'Header labeled "Recharge below gaps" in table 4 of Osterkamp and others (1995) equals recharge from precipitation on piedmont plain, calculated as (piedmont drainage area) $\times(3.42$ percent $) \times(31$-mm index-storm precipitation).

${ }^{\text {eEquals }} 3.4$ percent of $31 \mathrm{~mm}$, the estimated index-storm precipitation for Al Ain and piedmont plain.

'Header labeled "Recharge above gaps" in table 4 of Osterkamp and others (1995) includes estimated subsurface inflow at mountain gap, intergap recharge along the front of the Oman Mountains, and surface infiltration into the wadi channel below mountain gap.

${ }^{g}$ Calculated using a total drainage basin area of $2,871.4 \mathrm{~km}^{2}$

${ }^{\mathrm{h}}$ Calculated using a total area of $6,290.3 \mathrm{~km}^{2}$ for Oman Mountains drainages and piedmont plain. 


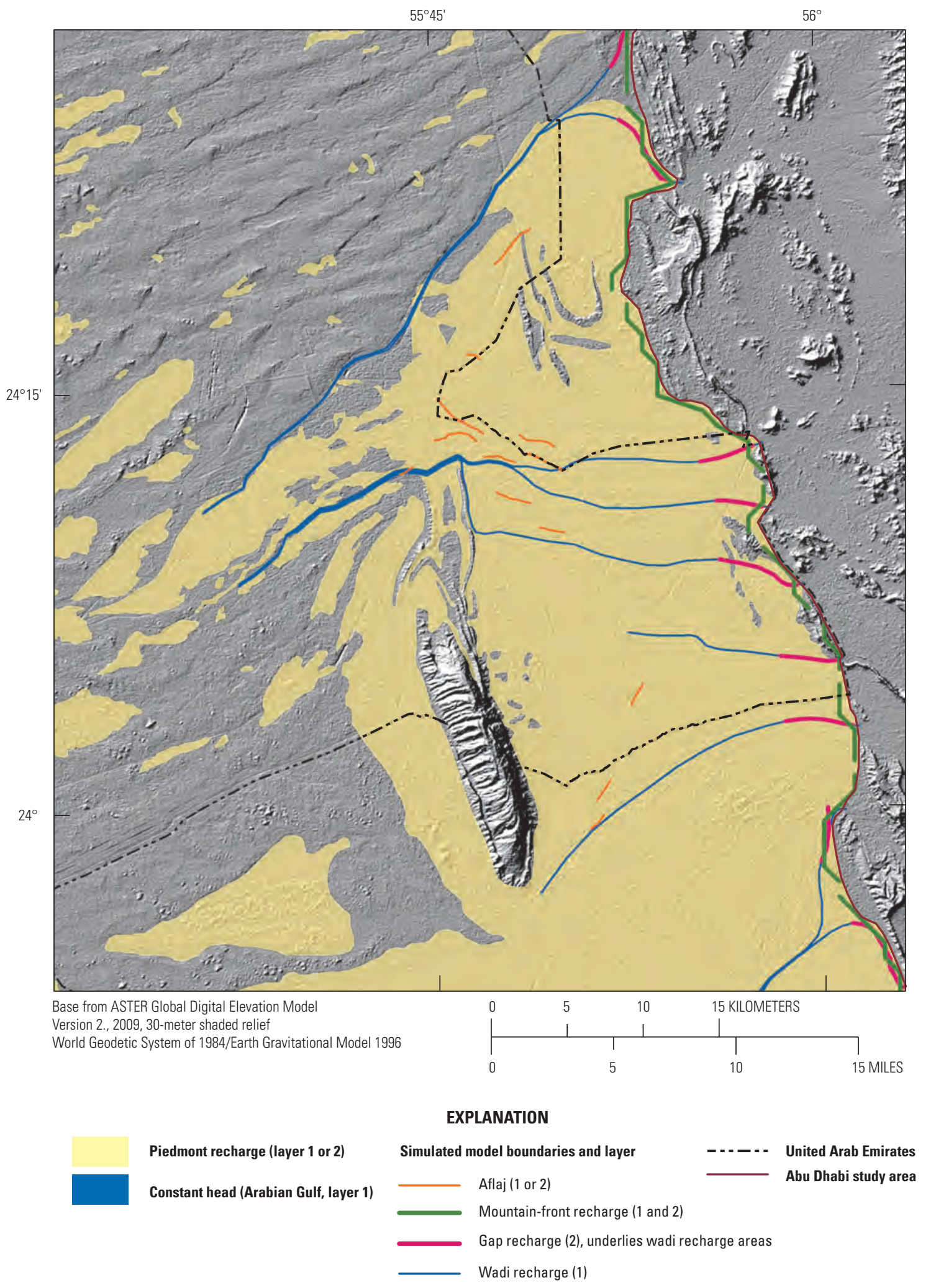

Figure 12. Aflaj locations in the Al Ain area of the study area, eastern Emirate of Abu Dhabi, United Arab Emirates. 
A water-balance model was applied by Osterkamp and others (1995) to estimate piedmont and mountain-front recharge as a percentage of the index-storm event. Piedmont recharge, resulting from infiltration of precipitation on the piedmont plain, equaled about $1 \mathrm{~mm} / \mathrm{yr}$, or 3.42 percent of the index-storm event of $31 \mathrm{~mm} / \mathrm{yr}$, and was equivalent to a volumetric recharge rate of $3.6 \mathrm{Mm}^{3} / \mathrm{yr}$ to the aquifer in the piedmont. The same percentage ( 3.42 percent) was applied to index-storms for each drainage basin in the Oman Mountains to estimate mountain-front recharge, averaging about $2 \mathrm{~mm} / \mathrm{yr}$ for all basins and providing $5.6 \mathrm{Mm}^{3} / \mathrm{yr}$ of recharge to the aquifer through the eastern boundary. As a percentage of total mean annual precipitation, rainfall recharge equaled about 1 percent for the piedmont plain, equaled about 11 percent for the Oman Mountains, and averaged about 7 percent for the combined areas (Osterkamp and others, 1995). Total mean annual recharge estimated by Osterkamp and others (1995) for recharge components originating in the Oman Mountains - wadi, gap, and mountain-front — equaled $51.7 \mathrm{Mm}^{3} / \mathrm{yr}$ (table 3).

Recharge estimates by Osterkamp and others (1995) are essentially uncalibrated, in that no regional groundwater budget was developed to balance recharge and natural discharge volumes, and no comparisons were made to other independent estimates of individual or total recharge because of limited available information for the eastern region. For example, as of 2016, periodic and diffuse wadi flow draining the western flank of the Oman Mountains has not been measured, and associated recharge has not been estimated. However, individual recharge processes are supported by secondary information. For example, water levels rise in some wells that are adjacent to wadis during floods (Moreland and others, 2007). Additionally, no independent, systematic estimate has been made for mountain-front recharge, but patterns of potentiometric contours for the surficial aquifer and salinity contours for groundwater showing salinity of less than 1,500 milligrams per liter $(\mathrm{mg} / \mathrm{L})$ dissolved solids adjacent to the mountain front (Imes and Clark, 2006) both support the occurrence of recharge from fractured rock in the Oman Mountains.

In addition to Osterkamp and others (1995), rainfall recharge for the piedmont and interdunal areas of the eastern region was estimated by several other studies as a percentage of mean annual precipitation. Using a groundwater flow model, Imes and others (1993) estimated a net infiltration rate of 0.57 cubic meter per second $\left(\mathrm{m}^{3} / \mathrm{s}\right)$ by assuming rainfall recharge equaled 1.0 to 2.5 percent of mean annual precipitation. On the lower range of estimated recharge, Imes and Wood (2007) applied a solute-mixing model to estimate rainfall recharge rates of 0.06 and 0.5 percent of mean annual precipitation at two inter-wadi locations, but they concluded that virtually all rainfall on the piedmont or interdunal areas evaporated before reaching the water table. On the higher range of estimated recharge, Maddy (1993) assumed that 5 percent of precipitation falling on the gravel plains and interdunal areas infiltrates and recharges the water table. Limited recharge from rainfall and recharge rates of less than
1 percent of mean annual precipitation more closely represent findings for arid regions of the United States. For example, using a distributed parameter water-balance model for the southwestern United States with mean annual precipitation ranging from about 150 to 450 millimeters (mm), Flint and Flint (2007) estimated the ratio of recharge to precipitation to be less than 1 percent for most areas.

Recharge of rainfall on areas of dune sand (about 66 percent of the eastern region) is likely to be zero or very limited. Dincer and others (1974) found that for sand dunes with a mean grain size of $0.20 \mathrm{~mm}$, mean annual precipitation must exceed $150 \mathrm{~mm}$ to induce deep infiltration and potential recharge. Mean grain size from five samples collected from the crests of sand dunes near the eastern region (Besler, 1982) averaged $0.18 \mathrm{~mm}$, and mean annual precipitation in the study area ranged from 60 to less than $110 \mathrm{~mm}$ (fig. 3). Therefore, little recharge to the surficial aquifer is expected to occur in areas where the surface cover is eolian sand (fig. 10). The lack of aquifer recharge in sand dune areas in the eastern region is supported by field observation during intense storms (Imes and Wood, 2007).

Estimates of gap recharge have been made for some Oman Mountains drainages through a Darcian approach of estimating the product of channel-deposit cross-sectional area, aquifer hydraulic conductivity, and water-level gradient. Estimates of gap recharge for two of the larger and more commonly known drainages, Maḩd̦ah/Kahāl and Zarūb, ranged from 5-20 $\mathrm{Mm}^{3} / \mathrm{yr}$ and $8-15 \mathrm{Mm}^{3} / \mathrm{yr}$, respectively (Gibb and Partners, 1970b; Saines and Ansari, 1985; Remington, 1986). In comparison, estimates of gap recharge by Osterkamp and others (1995) were on the lower end of these ranges, about $5 \mathrm{Mm}^{3} / \mathrm{yr}$ for Maḩd̦ah/Kahāl and $8 \mathrm{Mm}^{3} / \mathrm{yr}$ for Zarūb.

\section{Discharge and Water Use}

Discharge from the aquifer system occurs as evapotranspiration (ET), groundwater discharge to the Arabian Gulf, and water use from wells and aflaj (figs. 9 and 12). Potential evaporation is high in the study area, with measured pan evaporation rates between 1.4 and 4.9 meters per year $(\mathrm{m} / \mathrm{yr})$ reported for Al Ain (Halcrow and others, 1969a, tables 13-15; Gibb and Partners, 1970b, appendix 5; National Drilling Company, 1992 , p. 4). Mean annual temperature in the study area for the period $1950-2000$ was $27.3{ }^{\circ} \mathrm{C}$ based on WorldClim data (Hijmans and others, 2005). The lack of natural vegetation over most of the study area indicates minimal transpiration by plants. By 1991, agriculture based primarily on groundwater withdrawals had expanded to $370 \mathrm{~km}^{2}$ (Imes and others, 1993), about 1.4 percent of the study area in this investigation. But during predevelopment times, which are represented by the model developed in this investigation, transpiration would have been limited to much smaller areas occupying far less than 1 percent of the study area.

Groundwater discharge as evapotranspiration occurs when the water table is within the root zone of phreatophyte 
plants or close to land surface in bare-soil areas (Nimmo, 2006). The maximum water-table depth at which substantial evaporation from the water table to the land surface can occur is likely about $4 \mathrm{~m}$, based on reports of salinization to that depth (Imes and others, 1993, p. 270) and observed shallow water-table depths in coastal and inland sabkhas and desert plains (Czarnecki and others, 1999; Hutchinson, 2006). In sabkhas and interdunal areas, the water table is typically close to the land surface. When the water table rises with recharge, groundwater is exposed to atmospheric influences and evaporates until the water table recedes below the zone of evaporation (Sanford and Wood, 2001). However, as from playas studied in desert regions of the United States (Garcia and others, 2015) evaporation from sabkha areas typically is low because of fine-grained sediments and salt crusts that limit the upward movement of the water table.

The amount of groundwater discharge to the Arabian Gulf (fig. 11) as offshore springs or seepage has been estimated on the basis of water-balance calculations (Imes and others, 1993; Sanford and Wood, 2001). Imes and others (1993) simulated groundwater flow in the eastern region and estimated that 40 percent of all flow in the eastern region aquifer discharges to the gulf, with the remaining 60 percent of the flow exiting through evaporation. However, Sanford and Wood (2001) measured evaporation from the coastal sabkhas and, on the basis of more localized groundwater flow model simulations, estimated that only about 0.15 percent of groundwater flow discharged to the gulf, with the remaining 99.85 percent discharging by evaporation. Given that estimates of evaporation in the coastal marine region are not directly known, estimates of regional discharge rates to the gulf can be considered uncertain.

Water for domestic and agricultural supplies during the predevelopment period was supplied by shallow dug wells and falaj systems (Hutchinson, 2006). The shallow dug wells used hand-operated pumps, and therefore predevelopment rates of groundwater withdrawals from wells were likely to be very low. A falaj (plural, aflaj) is a network of dug well shafts connected by horizontal tunnels that access the water table and deliver water to a downgradient surface discharge. Aflaj were in use in the study area during predevelopment times. The aflaj systems typically consist of vertical access shafts spaced 10 to $30 \mathrm{~m}$ apart and a connecting horizontal tunnel that conveys water to an oasis or farm. The most upgradient vertical access shaft, or "mother well," is typically 10 to $20 \mathrm{~m}$ deep (Tadros and Huneidi, 1994). The connecting tunnel skims water from the water table. The depth of the mother well is a function of the depth to the surface of the water table and the ability to dig wells by hand. Aflaj in the eastern region of the Emirate were typically $1 \mathrm{~km}$ to several kilometers long, with the longest being $10 \mathrm{~km}$ long (Tadros and Huneidi, 1994). The network of aflaj in the study area, which can still be observed (2016) through aerial or satellite photography, included at least 13 systems in the $\mathrm{Al}$ Ain area adjacent to the Oman Mountains (fig. 12). Eight of the aflaj were still operational and yielding at a combined flow rate of approximately 300 liters per second (L/s) in 1964 (Tadros and Huneidi, 1994). Although operational aflaj depress the water-table locally, they probably have relatively little effect on regional groundwater flow patterns. Aflaj water use during this period was regulated by village elders, and water was likely to be efficiently used so that nearly all the groundwater withdrawals were consumed by domestic uses and agriculture with little to no return to the aquifer (Rizk, 1998; Brook and Al Houqani, 2006). Records show that, although aflaj flow rates in the study area were stable through the 1960s, declines begin in the mid-1970s, and by the early 1980s many of the monitored aflaj had ceased to flow (Tadros and Huneidi, 1994). Currently (2016), the few aflaj that flow in $\mathrm{Al}$ Ain are augmented by pumped well water (Brook and Al Houqani, 2006).

\section{Groundwater Levels}

Groundwater-level observations representative of predevelopment conditions, those considered to be relatively unaffected by pumping and other human influences, were compiled (Mack and others, 2020) from existing publications (Imes and others, 1993; Imes and Clark, 2006) and records maintained by EAD (Environment Agency-Abu Dhabi, written commun., 2015). These records provide 820 groundwater levels measured between 1977 and 2010, most of which were measured before 2004. More than 1,000 additional measured levels were excluded from the compilation because the wells had incomplete well construction or land-surface elevation records or were likely to have been affected by pumping. Although the levels are believed to be representative of predevelopment conditions, the effect of nearby pumping on the measured water levels is unknown; therefore, actual predevelopment water levels might have been higher than some of the measured levels. The measured levels (Mack and others, 2020) were also interpolated to form a predevelopment groundwater surface across the entire study area (fig. 13) modified from that produced by Imes and Clark (2006).

\section{Groundwater Model Development}

A numerical groundwater model was developed to simulate average steady-state groundwater under predevelopment conditions. The model was developed to integrate hydrogeologic information describing groundwater in eastern Abu Dhabi, test a conceptual model of groundwater flow, and provide a better understanding of regional groundwater flow prior to the onset of modern pumping. The model was designed to simulate regional groundwater flow, including flow in the shallow Quaternary aquifer and deeper sediments, but not local conditions at a point or around a single well. Finite-difference methods were employed by using MODFLOW-2005 (Harbaugh, 2005) software to solve the groundwater flow equations. Model parameters assigned to hydrogeologic units and hydrogeologic zones were used with 
$56^{\circ}$

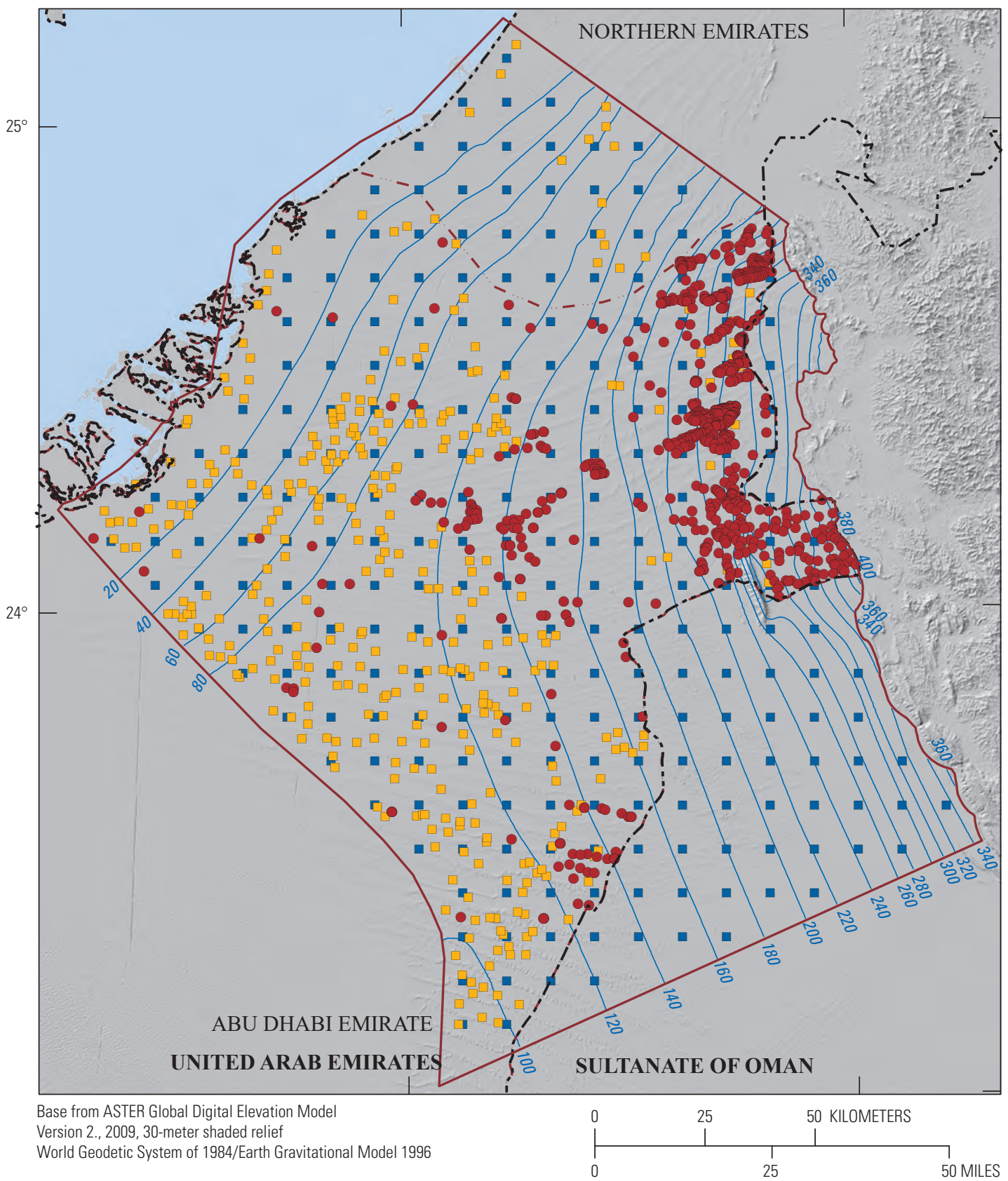

EXPLANATION

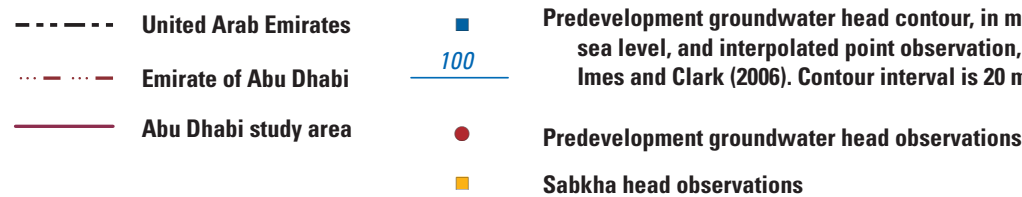

Figure 13. Locations of observed predevelopment groundwater levels and interpolated predevelopment water-table surface, eastern Emirate of Abu Dhabi, United Arab Emirates. 
MODFLOW-2005 and UCODE_2014 (Poeter and others, 2014) to facilitate sensitivity testing and estimation of hydraulic characteristics in a zonal approach. Parameters were used with all simulated hydraulic conductivities and boundary fluxes to assess the relative sensitivity and correlation of the various model components in model scenarios and to facilitate hypothesis testing of selected components of the flow system. Model datasets are available in the model archive data release (Mack and others, 2020).

The $27,000-\mathrm{km}^{2}$ study area corresponds to the area simulated by the model, or model area (fig. 1), and is defined by natural physiographic or groundwater flow boundaries. The northern part of the model area includes the region near the Arabian Gulf and the border with the Northern Emirates, and the southern border of the model area roughly coincides with a natural groundwater flow boundary. The northern and southern boundaries represent natural groundwater divides, based on contours of predevelopment groundwater levels (fig. 13). The Oman Mountains form the eastern boundary of the model area, and the western boundary represents a regional groundwater discharge area defined by a series of north-south-trending interdunal and coastal sabkhas (figs. 1 and 2). Although findings and discussion of the groundwater flow system are limited to groundwater resources located within eastern $\mathrm{Abu}$ Dhabi Emirate, accurate simulation of groundwater resources required the inclusion of natural flow system boundaries located short distances into Dubai Emirate and the Northern Emirates to the north and into Oman to the east.

\section{Model Discretization and Hydrogeologic Characterization}

The model grid encompassing the study area (figs. 11 and 14) is oriented north-south so that the primary direction of groundwater flow, east-west, generally coincides with model rows. The grid has 491 rows, 421 columns, and 5 layers. Most layer 1 and 2 cells (52.6 and 52.3 percent) are active, with deeper layers (37, 37, and 26 percent) having fewer active cells (fig. 14) because the hydrogeologic units they represent are not present over much of the study area. The approximate elevation of the bottom active layer in meters above (or below) sea level is shown in figure 14 .

Model cell dimensions are uniformly $500 \mathrm{~m}$ by $500 \mathrm{~m}$ horizontally, and they vary vertically according to thickness changes within each simulated unit. With its horizontal cell area of 250,000 square meters $\left(\mathrm{m}^{2}\right)\left(0.25 \mathrm{~km}^{2}\right)$, the model is best suited to simulate large-scale aquifer features such as overall water balances, flow directions, and volumes. The model is not designed for simulation of site-specific hydraulic changes or groundwater features at scales of less than a few kilometers.

Cell thickness varies depending on the hydrogeologic unit represented, with all active cells specified to be at least $4 \mathrm{~m}$ thick to prevent thin cells (fig. 15). Where hydrogeologic units are thinner than $4 \mathrm{~m}$, cells were either assigned a thickness of $4 \mathrm{~m}$ or made inactive if the underlying layer was inactive. In general, predevelopment, steady-state groundwater flow is likely to be predominantly horizontal and concentrated in the upper part of the aquifer system. Therefore, model layers were designed to be thin near the surface, where fluxes enter and leave the model, and become increasingly thick with depth (fig. 15).

Model layers were designed to represent the primary hydrogeologic units described previously ("Hydrogeologic Framework") (table 4). Model layers 1 and 2 represent shallow (generally less than $50 \mathrm{~m}$ ) sediments that form the surficial aquifer. The bottoms of model layers 3,4 , and 5 represent the maximum depth of the upper post-Fars unit, lower postFars unit, and Upper Fars Formation, respectively (fig. 15). However, model layers crosscut and include overlying hydrogeologic units in some places. Therefore, numerical model layers do not necessarily follow the hydrogeologic units in all locations.

Layers 1 and 2 represent the surficial aquifer, where most fresh groundwater flow occurs and from which most current (2016) supply wells withdraw water. In active areas of the model, the mean thickness of layers 1 and 2 combined is approximately $47 \mathrm{~m}$. Layer 1 includes eolian dune sand, which covers 67 percent of the active model area (fig. 2). Layers 1 and 2 also include the shallow portions of upthrusted limestone units that in places reach the land surface (fig. 2).

The top of layer 1 represents the land surface (fig. 15), with elevations derived from Advanced Spaceborne Thermal Emission and Reflectance Radiometer (ASTER) Global Digital Elevation Model (GDEM) version 2 data (ASTER GDEM Validation Team, 2011). The GDEM surface elevations are provided at 30-m grid spacing, and the median GDEM elevation within each 500-m model cell was assigned as the elevation of the top of layer 1 . The median elevation, in each $500-\mathrm{m}$ cell, provides a smoothed representation of the land surface and eliminates high and low points that may be present within the 30-m GDEM surface. Elevations for most layers and for all flux boundaries are related to the smoothed landsurface (model top) elevation to avoid incorporating localized points of high or low elevation. However, the elevation of the model top at Jabal Hafit was truncated and set to an elevation interpolated from the surrounding cells to avoid propagating a local, extreme elevation contrast to the model layers beneath this feature. Model cells along the gulf were assigned a surface elevation of sea level $(0 \mathrm{~m})$ for the top of model layer 1 . The bottom elevation of model layer 1 (and top of model layer 2) was defined by assuming a thickness of $9 \mathrm{~m}$ for layer 1 everywhere in the model. The only exception is in areas of water deeper than $9 \mathrm{~m}$ in the gulf, where layer 1 cells were assigned thicknesses of more than $9 \mathrm{~m}$, which was done for about 2 percent of active cells in layer 1. Active model cells extend a few cells into the gulf to account for the possibility of exchange of water between the aquifer and the gulf.

Model layers 1 and 2 together represent the surficial aquifer and are set as active over most of the model (fig. 15). The bottom of model layer 2 coincides with the bottom of 


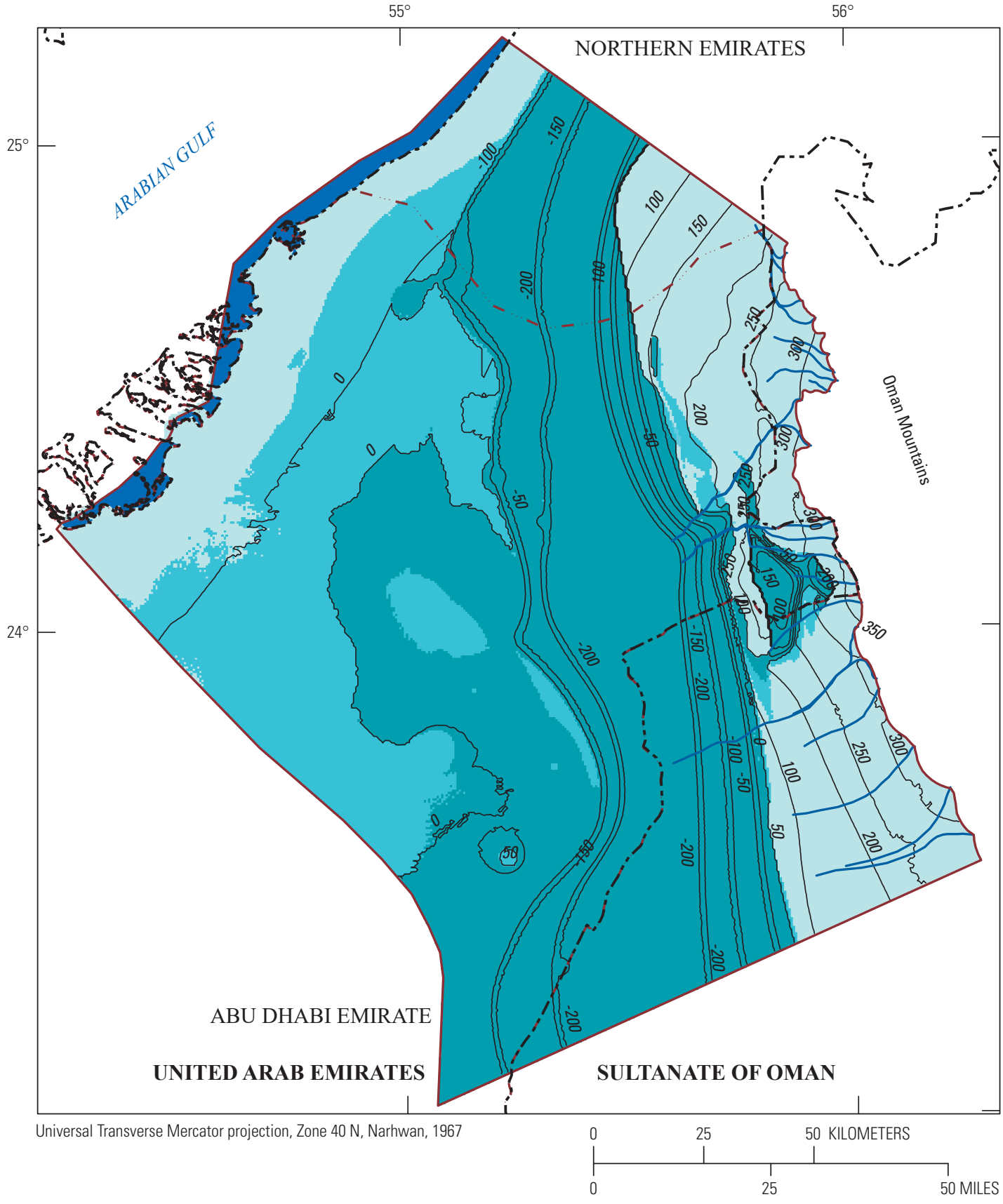

EXPLANATION

Simulated model active areas

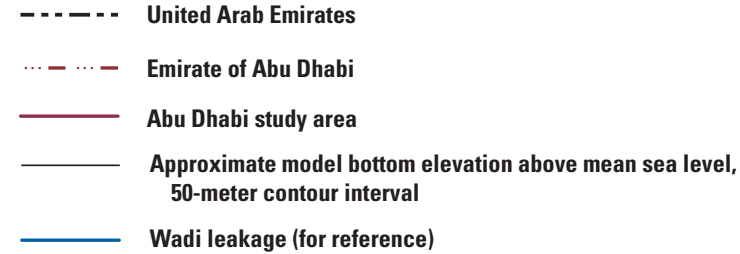

Figure 14. Active areas in model layers 1-5 and approximate model bottom elevation, eastern Emirate of Abu Dhabi, United Arab Emirates. 


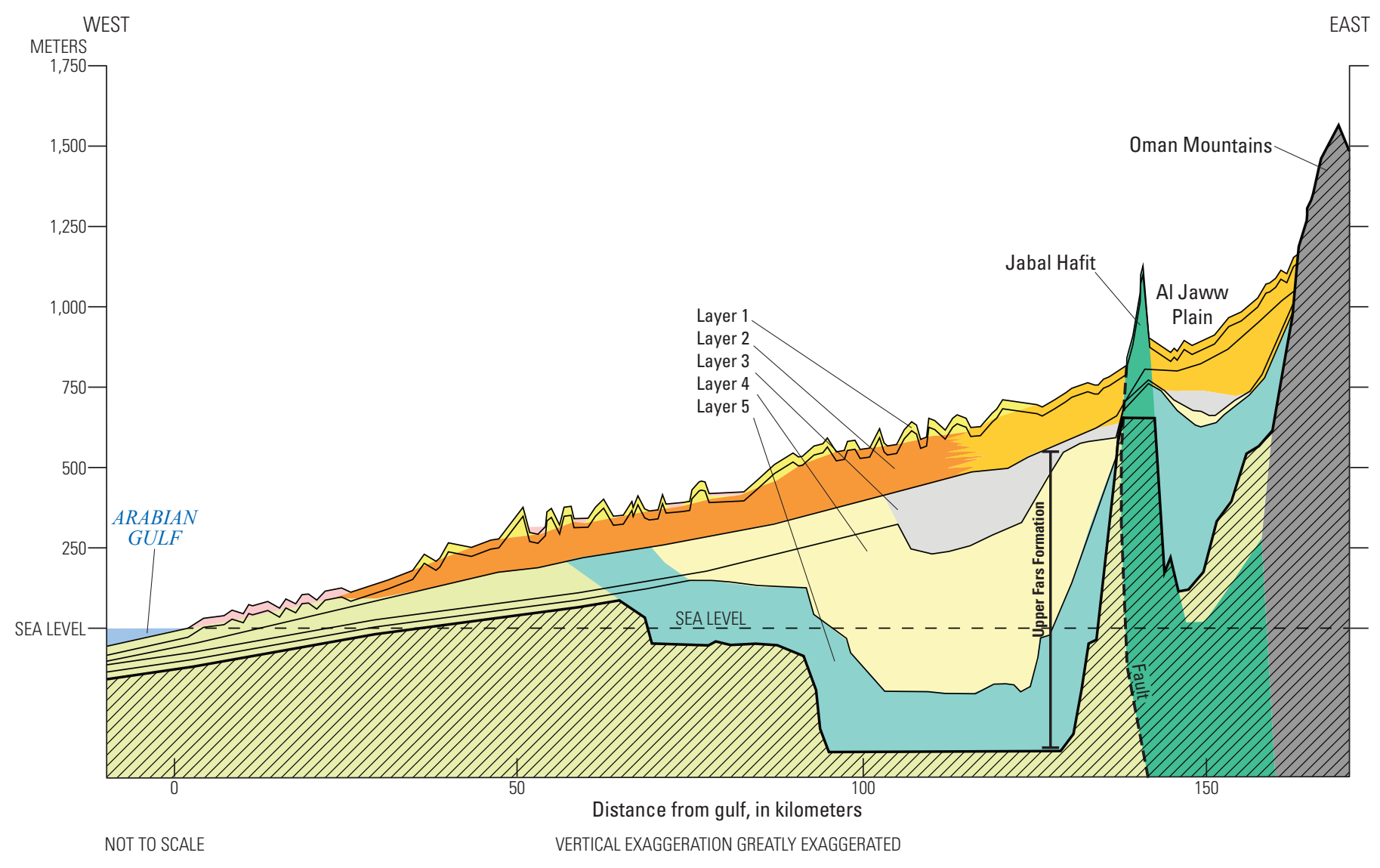

EXPLANATION

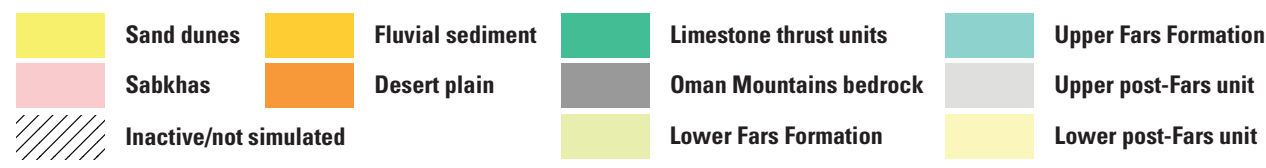

Figure 15. Generalized model layers and representation of hydrogeologic units for the predevelopment groundwater flow model of the eastern Emirate of Abu Dhabi, United Arab Emirates.

the surficial aquifer as defined by Imes and Clark (2006). The surficial aquifer contains multiple HGUs that incorporate the various landforms illustrated by the mapped surficial geology (fig. 2). In some areas, the base of the surficial aquifer (bottom of model layer 2) is aligned with the base of alluvial sediment, UPF, LPF, or UF units (see "Hydrogeologic Units and Regional Aquifer System" section). However, in other areas, particularly western areas of the model, the base of the surficial aquifer falls within the UPF, LPF, or UF HGUs.

Layer 3 primarily represents the upper post-Fars (UPF) unit in the areas of the model where UPF is present (figs. 6 and 15). The bottom of model layer 3 is equal to the interpreted bottom of the UPF unit discussed previously ("Hydrogeologic Units and Regional Aquifer System"), where present in relatively limited areas west and east of Jabal Hafit. The UPF unit is between about 8 to $47 \mathrm{~m}$ thick. Where the UPF unit is not present and either LPF or UF units are present, layer 3 was assigned a thickness of $8 \mathrm{~m}$ and represents the upper $8 \mathrm{~m}$ of one or both of those units. Where the LPF or UF units are not present, the bottom of layer 3 is the bottom of the active model (fig. 15).

Layer 4 primarily represents the lower post-Fars (LPF) unit (figs. 5 and 6), and the bottom of layer 4 corresponds to the interpreted bottom of the LPF unit. This unit has a larger areal extent than the UPF unit (fig. 6) and is up to $224 \mathrm{~m}$ thick at its deepest point in the sedimentary basin west of Al Ain. Where the LPF unit is not present and the UF unit is present, layer 4 represents the upper $16 \mathrm{~m}$ of the UF unit. Where the underlying UF unit is not present, the base of the LPF unit (bottom of layer 4) represents the base of the active model. Where the LPF or UF units are absent, layer 4 is inactive (figs. 14 and 15). 
Table 4. Model parameters for hydrogeologic units and boundary conditions for four model scenarios, eastern Emirate of Abu Dhabi, United Arab Emirates.

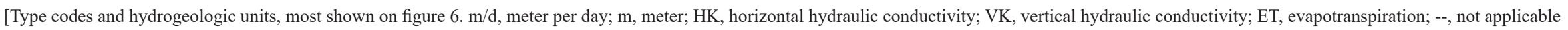
or not calculated]

\begin{tabular}{|c|c|c|c|c|c|c|c|c|}
\hline $\begin{array}{l}\text { Sediment group or } \\
\text { hydrogeologic unit }\end{array}$ & $\begin{array}{c}\text { Model } \\
\text { parameter }\end{array}$ & $\begin{array}{l}\text { Appli- } \\
\text { cable } \\
\text { layers }\end{array}$ & $\begin{array}{l}\text { Unit type codes or } \\
\text { hydrogeologic unit }\end{array}$ & Scenario 1 & Scenario 2 & Scenario 3 & Scenario 4 & Geology, notes \\
\hline & & & & \multicolumn{2}{|c|}{$\begin{array}{l}\text { Piedmont recharge, } \\
1 \text { percent of precipitation }\end{array}$} & \multicolumn{2}{|c|}{$\begin{array}{l}\text { Piedmont recharge, } \\
\text { 3.4 percent of precipitation }\end{array}$} & \\
\hline & & & & $\begin{array}{l}\text { Mountain- } \\
\text { front, gap, } \\
\text { and wadi } \\
\text { recharge, set } \\
\text { at Osterkamp } \\
\text { rates }^{2}\end{array}$ & $\begin{array}{c}\text { Mountain- } \\
\text { front, gap, } \\
\text { and wadi } \\
\text { recharge, } \\
\text { optimized up } \\
\text { to } 50 \text { percent } \\
\text { of Osterkamp } \\
\text { rates }^{2}\end{array}$ & $\begin{array}{l}\text { Mountain- } \\
\text { front, gap, } \\
\text { and wadi } \\
\text { recharge, set } \\
\text { at Osterkamp } \\
\text { rates }^{2}\end{array}$ & $\begin{array}{c}\text { Mountain- } \\
\text { front, gap, } \\
\text { and wadi } \\
\text { recharge, } \\
\text { optimized up } \\
\text { to } 50 \text { percent } \\
\text { of Osterkamp } \\
\text { rates }^{2}\end{array}$ & \\
\hline & & & & $\begin{array}{l}\text { Horizontal } \\
\text { hydraulic } \\
\text { conductivity } \\
(\mathrm{m} / \mathrm{d})\end{array}$ & $\begin{array}{l}\text { Horizontal } \\
\text { hydraulic } \\
\text { conductivity } \\
\text { (m/d) }\end{array}$ & $\begin{array}{l}\text { Horizontal } \\
\text { hydraulic } \\
\text { conductivity } \\
(\mathrm{m} / \mathrm{d})\end{array}$ & $\begin{array}{l}\text { Horizontal } \\
\text { hydraulic } \\
\text { conductivity } \\
(\mathrm{m} / \mathrm{d})\end{array}$ & \\
\hline Dune & HK_Dune & 1 & Qd & 10 & 5.3 & 10.6 & 6.7 & $\begin{array}{l}\text { Aeolian fine sand at surface, } \mathrm{VK} \text { is assumed } \\
\mathrm{HK} \times 0.1\end{array}$ \\
\hline Desert plain & HK_Fluv & 1,2 & $\begin{array}{l}\text { Qes and Qes/(QTm, } \\
\text { Qm, Qsb, Tm, Qtm) }\end{array}$ & 1 & 0.65 & 1.06 & 0.5 & $\begin{array}{l}\text { Eolian sand, and mixed sediments (Qtm), } \\
\quad \text { VK is assumed } \mathrm{HK} \times 0.1\end{array}$ \\
\hline Fluvial sediments & HK_Plain & 1,2 & Qg and $\mathrm{Qg} /(\mathrm{Qm}, \mathrm{Tm})$ & 5.7 & 2.8 & 5.6 & 2.5 & Fluvial sediments, $\mathrm{VK}$ is assumed $\mathrm{HK} \times 0.1$ \\
\hline Sabkhas & HK_Sab & 1 & Qsb & 0.001 & 0.001 & 0.01 & 0.01 & Sabkha calcareous, $\mathrm{VK}$ is assumed $\mathrm{HK} \times 0.01$ \\
\hline $\begin{array}{r}\text { Fine-grained } \\
\text { sediments }\end{array}$ & HK_Fine & 1,2 & Qtf, Tm & 2 & 2 & 1.5 & 1.5 & $\begin{array}{l}\text { Tidal flats, marsh, and evaporites, } \\
\text { VK is assumed } \mathrm{HK} \times 0.1\end{array}$ \\
\hline Upper post-Fars & HK_UPF & 3 & UPF & 0.06 & 0.043 & 0.0009 & 0.09 & $\begin{array}{l}\text { Relatively higher permeability for deep sedi- } \\
\text { ments, VK is assumed } \mathrm{HK} \times 0.1\end{array}$ \\
\hline Lower post-Fars & HK_LPF & 3,4 & LPF & 0.025 & 0.014 & 0.003 & 0.026 & $\begin{array}{l}\text { Moderate permeability for deep sediments, } \\
\text { VK is assumed } \mathrm{HK} \times 0.1\end{array}$ \\
\hline Upper Fars & HK_UF & $3,4,5$ & UF & 0.084 & 0.042 & 0.1 & 0.087 & $\begin{array}{l}\text { Moderate permeability for deep sediments, } \\
\text { VK is assumed } \mathrm{HK} \times 0.1\end{array}$ \\
\hline Upthrust units & HK_Rxu & 1,2 & Tle, Tlo, K & 1.2 & 0.59 & 1.08 & 0.61 & $\begin{array}{l}\text { Low-permeability shales, mudstones, and } \\
\text { carbonates including Asmari, Dammam and } \\
\text { other formations, VK is assumed equal to HK }\end{array}$ \\
\hline Bedrock & HK_RX & 1,2 & $\begin{array}{l}\text { Qm, Qc, K, Sp, Tlo, } \\
\text { Tle }\end{array}$ & 0.02 & 0.01 & 0.01 & 0.01 & $\begin{array}{l}\text { Low-permeability unweathered rock, including } \\
\text { ophiolites and other formations, VK is as- } \\
\text { sumed equal to HK }\end{array}$ \\
\hline
\end{tabular}




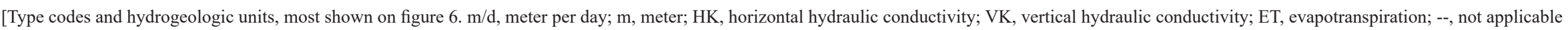
or not calculated]

\begin{tabular}{|c|c|c|c|c|c|c|c|c|}
\hline $\begin{array}{l}\text { Sediment group or } \\
\text { hydrogeologic unit }\end{array}$ & $\begin{array}{l}\text { Model } \\
\text { parameter }\end{array}$ & $\begin{array}{l}\text { Appli- } \\
\text { cable } \\
\text { layers }\end{array}$ & $\begin{array}{l}\text { Unit type codes or } \\
\text { hydrogeologic unit }\end{array}$ & Scenario 1 & Scenario 2 & Scenario 3 & Scenario 4 & Geology, notes \\
\hline & & & & \multicolumn{2}{|c|}{$\begin{array}{c}\text { Piedmont recharge, } \\
1 \text { percent of precipitation }\end{array}$} & \multicolumn{2}{|c|}{$\begin{array}{c}\text { Piedmont recharge, } \\
3.4 \text { percent of precipitation }\end{array}$} & \\
\hline & & & & $\begin{array}{l}\text { Mountain- } \\
\text { front, gap, } \\
\text { and wadi } \\
\text { recharge, set } \\
\text { at Osterkamp } \\
\text { rates }^{2}\end{array}$ & $\begin{array}{c}\text { Mountain- } \\
\text { front, gap, } \\
\text { and wadi } \\
\text { recharge, } \\
\text { optimized up } \\
\text { to } 50 \text { percent } \\
\text { of Osterkamp } \\
\text { rates }^{2}\end{array}$ & $\begin{array}{l}\text { Mountain- } \\
\text { front, gap, } \\
\text { and wadi } \\
\text { recharge, set } \\
\text { at Osterkamp } \\
\text { rates }^{2}\end{array}$ & $\begin{array}{c}\text { Mountain- } \\
\text { front, gap, } \\
\text { and wadi } \\
\text { recharge, } \\
\text { optimized up } \\
\text { to } 50 \text { percent } \\
\text { of Osterkamp } \\
\text { rates }^{2}\end{array}$ & \\
\hline & & & & $\begin{array}{l}\text { Horizontal } \\
\text { hydraulic } \\
\text { conductivity } \\
\text { (m/d) }\end{array}$ & $\begin{array}{l}\text { Horizontal } \\
\text { hydraulic } \\
\text { conductivity } \\
(\mathrm{m} / \mathrm{d})\end{array}$ & $\begin{array}{l}\text { Horizontal } \\
\text { hydraulic } \\
\text { conductivity } \\
(\mathrm{m} / \mathrm{d})\end{array}$ & $\begin{array}{l}\text { Horizontal } \\
\text { hydraulic } \\
\text { conductivity } \\
(\mathrm{m} / \mathrm{d})\end{array}$ & \\
\hline Flux boundary ${ }^{2}$ & $\begin{array}{c}\text { Model } \\
\text { parameter }\end{array}$ & $\begin{array}{l}\text { Appli- } \\
\text { cable } \\
\text { layers }\end{array}$ & $\begin{array}{l}\text { Conductance, } \\
\text { or rate multiplier } \\
\text { (dimensionless) }\end{array}$ & Value & Value & Value & Value & Boundary condition, notes \\
\hline ET & EVT_P1 & 1,2 & Rate $(\mathrm{m} / \mathrm{d})$ & $1.70 \times 10^{-4}$ & $1.70 \times 10^{-4}$ & $3.4 \times 10^{-4}$ & $2.9 \times 10^{-4}$ & $\begin{array}{l}\text { ET in sabkhas, desert plain (piedmont), fluvial } \\
\text { sediments, and fine-grained sediments }\end{array}$ \\
\hline $\begin{array}{l}\text { ET extinction } \\
\text { depth }\end{array}$ & EXDP & 1,2 & Length (m) & 2 & 2 & 2 & 2 & $\begin{array}{l}\text { ET extinction depth in sabkhas, alluvium, and } \\
\text { fine-grained sediments }\end{array}$ \\
\hline Gap recharge & TRLSAG & 1 & Multiplier & 1 & 0.51 & 1 & 0.5 & -- \\
\hline Wadi recharge & TRLSBG & 1 & Multiplier & 1 & 1.5 & 1 & 1.5 & -- \\
\hline Mountain front & IWRAG & 2 & Multiplier & 1 & 5.3 & 1 & 0.66 & -- \\
\hline Piedmont recharge & RHCP & $\begin{array}{l}\text { Highest } \\
\text { active }\end{array}$ & Multiplier & 0.01 & 0.01 & 0.034 & 0.034 & $\begin{array}{l}\text { Multiplier of precipitation in sabkhas, desert } \\
\text { plain (piedmont), fluvial sediments, and fine- } \\
\text { grained sediments }\end{array}$ \\
\hline Gulf constant head & CHD & 1 & Conductance & 0 & 0 & 0 & 0 & -- \\
\hline Aflaj & DRN & 1,2 & $\begin{array}{l}\text { Conductance multi- } \\
\text { plier }\end{array}$ & 2 & 2 & 2 & 2 & -- \\
\hline
\end{tabular}


Layer 5 represents the lower part of the Upper Fars (UF) unit. The bottom of layer 5 is equal to the interpreted bottom of the UF unit and is the base of the active model area where the UF unit is present. This surface coincides with the top of the Lower Fars Formation unit, which is not considered to be part of the regional groundwater flow system because of its considerably lower hydraulic conductivity. Layer 5 is generally 200 to $300 \mathrm{~m}$ thick and at least $32 \mathrm{~m}$ thick. Where the UF unit is absent, layer 5 is inactive (fig. 15).

\section{Boundary Conditions}

Groundwater flow conditions were assigned at all model boundaries. The bottom of the model represents bedrock, the LF unit, or relatively low hydraulic conductivity sediment and was assigned as a no-flow boundary. The northwestern model boundary aligned with the Arabian Gulf was assigned as a constant-head boundary, and all remaining model boundaries were assigned as no-flow boundaries (fig. 11). Although the eastern boundary of the model was assigned as a no-flow boundary, inflows were assigned along the eastern boundary by using the well (WEL) MODFLOW package and represent known groundwater inflow and wadi surface-runoff infiltration to the water table.

\section{Active Model Area}

The active model area comprises the freshwater aquifer and permeable sediments between the Oman Mountains and the gulf, bounded to the north and south by groundwater flow divides identified in previous studies (Imes and Clark, 2006; Imes and Wood, 2007). Ideally, boundaries of a groundwater model coincide with natural hydrologic boundaries: either impermeable boundaries or boundaries at which heads or fluxes are known. To achieve boundaries that more closely approximate these conditions, it was necessary to extend the active model area beyond the Abu Dhabi border into the Northern Emirates and Oman.

The southern model boundary coincides with a previously determined groundwater trough that acts as a flow divide stretching from Umm Al Zumool northwest to the gulf coast about $50 \mathrm{~km}$ southwest of the city of Abu Dhabi (Imes and Clark, 2006; Imes, 2012). The southern boundary was set approximately $25 \mathrm{~km}$ south of Al Quaa (fig. 3) to minimize the effects of boundaries on simulated heads and flows in Al Quaa. $\mathrm{Al}$ Quaa was included in the active model area because of the expansion of irrigated farms in that area and the possible need to simulate groundwater use in that area in the future.

The western model boundary coincides with the Arabian Gulf and was simulated as a constant-head boundary to the regional aquifer. The constant head was simulated by using the MODFLOW CHD package with an elevation of $0 \mathrm{~m}$ in model layer 1 . The eastern model boundary was extended to the bedrock outcrops of the Oman Mountains and simulated as a noflow boundary except for specified inflows to model layers 1 and 2. The northern model boundary was extended beyond the Abu Dhabi border into the Dubai Emirate to coincide with a groundwater flow path extending from the Oman Mountains to the gulf. The northern boundary, therefore, was simulated as a no-flow boundary.

\section{Lateral Boundary Fluxes}

Lateral fluxes simulated in model boundaries include groundwater exchange with the Arabian Gulf and inflow at the front of the Oman Mountains (figs. 11 and 12). The gulf, at sea level or $0 \mathrm{~m}$, sets the natural base level for the regional flow system. There is little fresh groundwater (water with a low dissolved-solids concentration), and there were no large groundwater withdrawals along the gulf boundary, so the freshwater and saltwater interface was not explicitly simulated in this study.

Lateral inflows along the eastern model boundary at the foot of the Oman Mountains were assigned parameters for sensitivity calculations (table 4) on the basis of the conceptualization described in the "Recharge" section (figs. 11 and 12; table 3). In the model, recharge from lateral inflow represents gap recharge and mountain-front recharge. Mountain-front recharge occurs as groundwater inflow to the aquifer through mountain bedrock (figs. 11 and 12). Initial model-input values for lateral inflow from mountain-front and gap recharge are equal to those estimated by Osterkamp and others (1995) (table 3). Osterkamp and others (2015) estimates of inter-wadi recharge above outcrop gaps (IWRAG) represent mountainfront recharge simulated as inflows to layers 1 and 2 boundary cells by using the MODFLOW WEL package. This flux was assigned the model parameter IWRAG, a unitless multiplier initially set equal to 1 . The estimates of groundwater inflow to the aquifer through alluvial fill deposits in mountain gaps were used to represent lateral inflow from gap recharge in the model. At each gap in the Oman Mountains along the eastern boundary of the model, the MODFLOW WEL package was used to assign a lateral inflow to model layer 2 using the unitless multiplier parameter TRLSAG, initially set equal to 1 .

\section{Vertical Boundaries-Recharge and Evapotranspiration}

The upper boundary of the model controls exchanges of water between the land surface and the water table. However, water held in the unsaturated zone between the land surface and water table is not explicitly simulated in the model. Inflow through the upper boundary, representing the land surface, occurs as piedmont recharge and transmission losses from wadis below mountain gaps (wadi recharge). Piedmont recharge to the aquifer is the fraction of precipitation that infiltrates from the land surface to the water table. The only outflow through the upper boundary is ET. The lower boundary of the model is the top of the Lower Fars (LF) Formation and is a no-flow boundary. 
Piedmont recharge, the infiltration of precipitation from the land surface to the water table, was distributed in the model on the basis of surface geology and spatially varied mean annual precipitation rates (figs. 2 and 3). Piedmont recharge was assigned by using parameter RHCP and was set to zero for inactive cells and for cells located in areas with eolian sand or upthrust limestone surface geology (fig. 11). Elsewhere, aereal recharge rates were set to 3.4 percent of mean annual precipitation rates (tables 3 and 4 ) for the uppermost active model cell.

Evapotranspiration was simulated in the model by using parameter EVT_P1 and the same areal zones as used for piedmont recharge. ET was set to zero for cells located in areas of eolian sand or upthrust limestone surface geology (fig. 11), which cover about 66 percent and 1 percent of the active model area, respectively. Although actual ET rates from the water table can vary considerably with salinity, groundwater salinity was not simulated or considered for application of ET rates in this study.

For active model cells representing areas of groundwater discharge, ET is calculated as a function of surficial geology, water-table depth below land surface, and assigned parameter values representing evaporation rates and depths. The actual ET rate for each cell is then calculated by the MODFLOW evaporation package (EVT package), using equation 1 (McDonald and Harbaugh, 1988):

$$
\begin{aligned}
E T & =E \operatorname{Tmax} *(\operatorname{Dext}-D) / \operatorname{Dext} \text { for } D \leq D e x t, \text { and } \\
E T & =0 \text { for } D>\operatorname{Dext}
\end{aligned}
$$

where

ET is the model-calculated evapotranspiration
rate, in meters per day;
is the assigned maximum evapotranspiration
rate, in meters per day;
is the simulated depth to water table, in
meters; and
is the assigned extinction depth, or water-table
depth, below land surface, in meters, at
which $E T$ diminishes to zero.
Dext
Under equation 1, ET rates vary linearly with water-table
h from ETmax, when the water table is at the land surface,
ro, when the water-table depth is at Dext. The variable
ax is assigned in the model by using parameters EVT_P0
EVT_P1. Parameter EVT_P0 is assigned to cells with
ET and has a fixed value of zero. Parameter EVT_P1 is
gned to all other cells and is estimated by the parameter
mation model, UCODE_2014 (Poeter and others, 2014).
effect of extinction depth (Dext) was also examined in
parameter estimation process and assigned the parameter
DP. This parameter was used in model scenarios to assess
effect and sensitivity of extinction depth in the groundwa-
fow system.
Model-input values for vertical inflow from wadi
arge are equal to those estimated by Osterkamp and others

runoff in wadis downstream of the Oman Mountains ("Transmission loss below mountain gaps" in table 3). Total recharge from wadis in the model is slightly higher than the total for Osterkamp because the model includes recharge from four wadis outside the study area of Osterkamp and others (1995). Recharge from these four wadis was estimated based on their mountain basin drainage area and the mean flow per unit area of the other wadis. Wadi recharge inflows were assigned to model layer 1 using the well MODFLOW well (WEL) package over the length of the delineated wadi. The WEL package was used to avoid the possibility of outflows that can occur if other MODFLOW boundary packages, such as the stream (STR) package, are used. The parameter TRLSBG was used to determine the sensitivity of the aquifer system to this flux, and it acts as a multiplier of the prescribed flux with an initial value of 1.0.

\section{Withdrawals}

The predevelopment conditions simulated in this study included no groundwater withdrawals from wells. Outflows from aflaj that were active and measured in 1964 (Tadros and Huneidi, 1994) were simulated by using the MODFLOW drain package (DRN), with model drain elevations set at $2 \mathrm{~m}$ below the top of layer 2 . This drain elevation corresponds to about $11 \mathrm{~m}$ below the land surface. While most falaj source wells were 10 to $20 \mathrm{~m}$ below land surface, the model cell is much wider than a falaj (500 $\mathrm{m}$ versus $1 \mathrm{~m}$ ), so a shallow drain elevation is a more realistic elevation to use than actual depth. Drains were placed in the upgradient one-half to one-third of the mapped aflaj length (fig. 12). No return flow from the aflaj back to the aquifer was simulated because the withdrawn water was likely to be entirely consumed. Measured flows at 7 Al Ain aflaj (Tadros and Huneidi, 1994) and estimated flows at 6 aflaj outside of $\mathrm{Al}$ Ain were used as flow observations for purposes of model calibration. A drain parameter (DRN), with an initial multiplier value of 1 , was used to calculate the sensitivity of the groundwater flow simulation to the simulated aflaj.

\section{Model Hydraulic Conductivity}

Horizontal and vertical hydraulic conductivity (HK and VK) were assigned parameters, as shown in table 4, for 10 units in the model. HK and VK parameter values were assigned by hydrogeologic unit, which were initially based on values from previous investigations (previous "Hydraulic Conductivity" section), and then were modified during model calibration. Vertical hydraulic conductivities are less well known than horizontal conductivities, and, therefore, values were assigned relative to horizontal hydraulic conductivity for parameter estimation. For example, the vertical hydraulic conductivity of layered sediment was set at an order of magnitude less than horizontal hydraulic conductivity. A HK to VK ratio of 10:1 is fairly common (Freeze and Cherry, 1979). The 
exception was sabkha sediments, which are layered and might contain evaporites, for which vertical hydraulic conductivity was set to 2 orders of magnitude less than horizontal because of expected layering. The horizontal and vertical hydraulic conductivities of bedrock units were given equal values because the conductivity is expected to be more isotropic for bedrock. The hydraulic conductivity of model cells simulated as water were set equal to $1,000 \mathrm{~m} / \mathrm{d}$ to provide a sufficiently large value to represent open water.

\section{Model Calibration}

The steady-state model was calibrated to observed values of groundwater levels (Mack and others, 2020) and aflaj flows, following the methods of Hill and Tiedeman (2007). Model calibration was performed through a process that included both automated parameter estimation, using UCODE_2014 (Poeter and others, 2014), and manual fitting of model parameters. The sensitivity of parameters was evaluated, as composite scaled sensitivities (CSS), simultaneously with the optimization of parameter values. This was in an iterative, semiautomated process in which parameters were estimated, less sensitive parameters were set at a fixed value, and the parameter estimation process was repeated.

Parameters used in the model include hydraulic characteristics used to define aquifer units and other features, such as ET (table 4-model parameter values). The model was calibrated in a regional manner, in which zones were used to represent hydrogeologic units (hydrologically consistent areas; see report section "Hydrogeologic Units and Regional Aquifer System") so that parameter values were held constant within zones. A close model fit between observed and simulated data could likely be obtained by locally adjusting cells within parameter zones; however, modifications made to match observations without a conceptual basis do not improve the understanding of hydrologic processes and might not result in a realistic model. Selected parameters, generally the lower sensitivity parameters as mentioned previously, were held constant or at a fixed ratio of an estimated parameter. For example, in the predevelopment scenario with no withdrawal stresses at depth in the system, vertical hydraulic conductivities were found to be relatively insensitive parameters. Vertical hydraulic conductivity, therefore, was treated as a derived parameter (Poeter and others, 2014) for subsequent parameter estimation simulations and held at a specified ratio with the estimated horizontal conductivity in the estimation process.

Model calibration is dependent on observations of the groundwater flow system. Observations are used to find the best fit model parameters, and the known or estimated errors of the observations are used to calculate the sensitivity of the groundwater flow model to the model parameters. Observations used to calibrate the predevelopment groundwater model included many $(1,342)$ groundwaterlevel observations (fig. 13; 820 measured heads, 279 heads estimated at sabkhas, and 243 map contoured heads) but few
(13) flow observations (fig. 12). In general, the weight of an observation is determined by its variance, which includes measurement error. For the predevelopment model, all observations are assumed to be representative of steady-state conditions although the observations are from different periods in time- this assumption is made to simplify numerical representation. With an accurate numerical representation of evenly distributed observations, the assigned weights would be based on observation variance and measurement error (Hill and Tiedeman, 2007). However, the assumption of steadystate observations, as well as other factors such as the actual elevation of an observation relative to the 500- $\mathrm{m}^{2}$ model cell's "smoothed" elevation, likely introduce more error into an observation than observation variance or measurement error. Therefore, the weights assigned to each observation group may be somewhat subjective and can be used to reflect prior knowledge of the hydrogeologic system. However, parameter values are generally not sensitive to moderate changes in the weights used (Hill and Tiedeman, 2007), and observations may be weighted as a group on the basis of relative value as discussed in the following section.

Estimates of inflows into the study area were available (table 3 ) at the eastern model boundary along the mountain front and help constrain estimated parameters. The estimated inflows were treated as parameters (table 4) in the parameter estimation process and were given an initial value of 1 to inform analysis of relative parameter sensitivity. The steadystate parameter sensitivity was calculated with all model layers simulated as nonconvertible (saturated) layers to linearize the numerical calculations. Although in the natural system some areas are likely to become unsaturated, simulating all layers in the numerical model as nonconvertible greatly simplifies the numerical calculations, allowing for solution of the parameter sensitivities. The simplification (linearization) approach used in this study is presented as a guideline for effective model calibration in Hill and Tiedeman (2007).

\section{Groundwater-Level Observations}

The measured predevelopment groundwater levels are all of the same approximate accuracy and are likely to be accurate within $0.1 \mathrm{~m}$ or less. A relative accuracy and weight was assigned to each groundwater-level observation for use in parameter estimation and model calibration. Groundwater levels in observation wells were reported with an accuracy of at least $0.1 \mathrm{~m}$, and most water levels had small seasonal ranges, typically less than $1 \mathrm{~m}$. Because measurements were collected over different seasons and years and because of the simplifying assumptions used, the water levels were assumed to be accurate within $1 \mathrm{~m}$. Therefore, a 95-percent confidence interval would provide a standard deviation of 0.51 . Allowing for potential errors in location and measurement point accuracy, the observation well heads were assigned a standard deviation of 1 .

Additional water-level observations were generated from mapped sabkhas for use in calibrating the model. A set 
of 279 sabkha head "observations" (fig. 13) was created from the lowest land-surface elevation (elevation data from ASTER GDEM Validation Team, 2011) at the center of mapped sabkha polygons under the assumption that groundwater levels were equal to $1.5 \mathrm{~m}$ below the land-surface elevation in the center of polygons (fig. 2). Because the majority of the predevelopment head measurements were collected from wells with land-surface elevations greater than $200 \mathrm{~m}$ in the eastern area of Abu Dhabi, the sabkha heads helped to provide a more widely distributed set of head observations than would be provided if only well measurements were used. The generated sabkha heads all were below an elevation of $140 \mathrm{~m}$ in the western and southern areas of the study area. The sabkha heads were based on the land-surface elevation for each cell, as derived from the digital elevation model, with little other potential source of error.

A set of simulated "map" predevelopment heads was created by selecting regularly spaced head values, with $10-\mathrm{km}$ spacing (fig. 13), from a previously created map of predevelopment heads (Imes and Clark, 2006). This dataset provides observations in areas of the model with few or no observations, particularly in the northern, southern, and western areas of the model, while also providing an evenly distributed set of head observations. Because the predevelopment mapped head surface was based on the predevelopment water levels, these heads also were assigned a standard deviation of 1 . Although the simulated "map" heads are not true observations, but rather interpolated or estimated heads, they serve the purpose of keeping simulated heads realistic in areas without true observations. The three head datasets (observed, sabkha, and simulated map, shown in fig. 13) were designated as observation groups in parameter estimation simulations to allow for examining model fit and parameter sensitivity by data group. UCODE_2014 allows for a weight-multiplication factor, and each head group was given a factor of 1 to simplify comparisons between groups.

The model scenario that uses recharge rates estimated by Osterkamp and others (1995) is considered to be the "base scenario" and has model conditions that are likely most representative of actual average predevelopment conditions. Overall, simulated groundwater levels for the base scenario are close to predevelopment groundwater-level observations and represent the range of more than $400 \mathrm{~m}$ in observed water levels (fig. 16A). The mean head residual for the base scenario was $0.50 \mathrm{~m}$, and the model standard error was $5.92 \mathrm{~m}$. The base scenario provided a better model fit than the other scenarios, which had mean residuals of from 1 to $1.8 \mathrm{~m}$, but because there is little information about predevelopment flows and therefore little constraint on mass balances, this judgment is somewhat subjective. Figure $16 B$ shows simulated groundwater levels with respect to weighted residuals. Given the model errors described previously, water levels should be within one standard model error $(5.92 \mathrm{~m})$. For the base scenario, most errors (74 percent) were within one standard model error and 96 percent were within two model standard errors (fig. 16B). Larger errors and errors less randomly
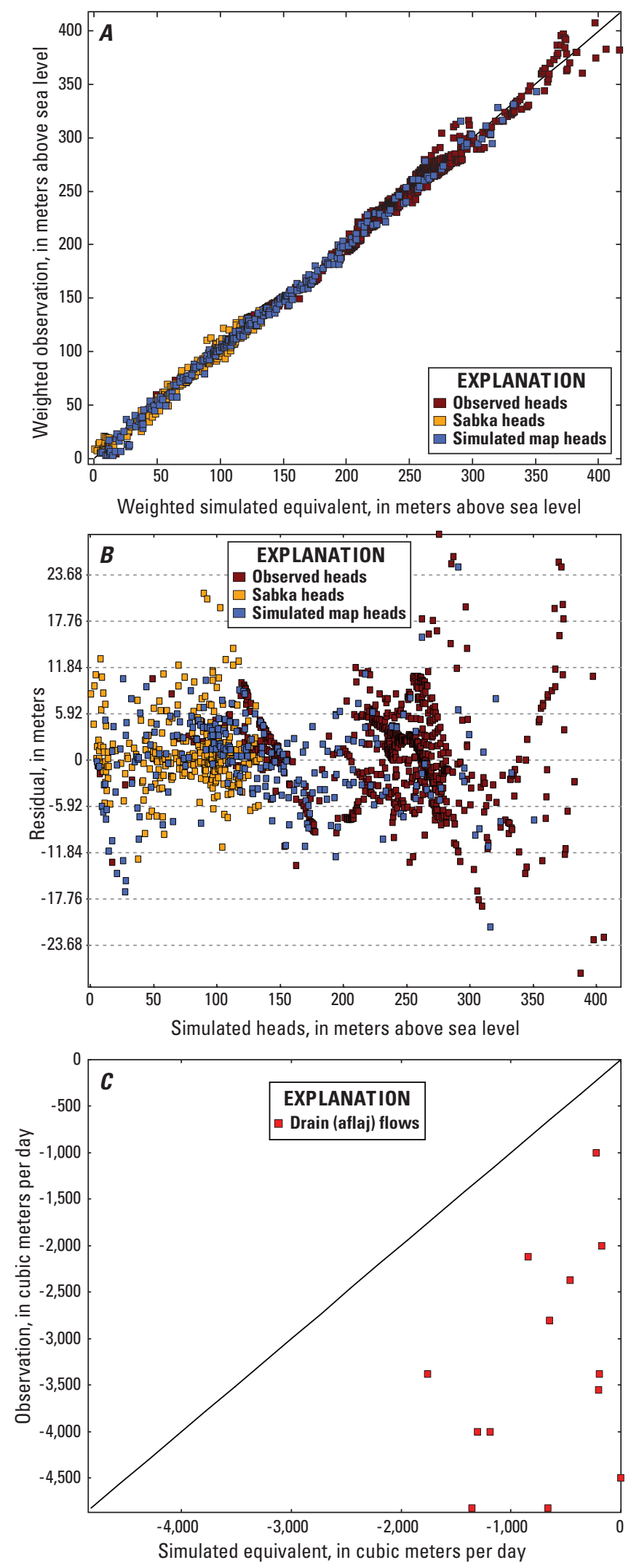

Figure 16. A, Observed and simulated groundwater levels, $B$, weighted residual and simulated groundwater levels, and $C$, observed and simulated aflaj flows for the predevelopment groundwater flow model of the eastern Emirate of Abu Dhabi, United Arab Emirates. 
distributed about the zero residual line (fig. 16B) occur near complex features such as Jabal Hafit and the eastern model boundary. Errors could also be attributed to incorporation of groundwater levels that might have been influenced by withdrawals that are not simulated in the predevelopment scenario. Several observations with known pumping effects were excluded from the calibration process; however, some groundwater levels that are affected by withdrawals might remain in the predevelopment dataset. The increased scatter in simulated heads at the eastern model boundary, those greater than $350 \mathrm{~m}$, is evenly distributed, indicating that heads in general are well simulated (fig. 16A). The greater error at the eastern boundary likely indicates that the conceptualization of the groundwater flow system in that area, where the aquifertest analyses indicated large contrasts in hydraulic conductivity ("Hydraulic Conductivity" section), would benefit from further hydrogeologic refinement.

Simulated predevelopment groundwater levels (fig. 17) are similar to the predevelopment head contours extrapolated from Imes and Clark (2006). The general predevelopment head pattern indicates the regional flow from the Oman Mountains westward to the Arabian Gulf. This simulation provides a base scenario for future withdrawal development simulations.

\section{Simulated Withdrawals}

Measured flows at $7 \mathrm{Al}$ Ain aflaj (Tadros and Huneidi, 1994) and estimated flows at 6 aflaj outside of Al Ain were considered observations of flow for this study. Although the observations are rough approximations with unknown observation error, flow was known to occur at these locations for many centuries. Therefore, aflaj discharges were assigned a coefficient of variation of 0.25 . The total observed falaj flow was not large (approximately 42,750 cubic meters per day $\left.\left[\mathrm{m}^{3} / \mathrm{d}\right]\right)$ and therefore, given the large number of head observations, does not contribute greatly to the parameter estimation and sensitivity analysis. Increasing the weight placed on falaj observations by an order of magnitude (10) did not greatly increase the sensitivity of these observations, and therefore the weight was left at 1 .

The total of the simulated falaj discharges in the base scenario $\left(9,020 \mathrm{~m}^{3} / \mathrm{d}\right)$ was about one-quarter of the estimated flow (fig. 16C). The mean weighted flow residual was -3.13 , which is less than one standard model error (5.92) given the data uncertainty and error described previously. Matching aflaj flow was not a high-priority objective of this simulation, given the level of uncertainty in the conceptual design and geometry of the simulated aflaj. The fit might have been improved by lowering drain cell elevations representing aflaj, but no attempt was made to further improve the simulated and observed fit, although future work could address this issue to better improve the simulations. Simulation of aflaj flow was useful in helping to understand the predevelopment flow system; however, a finer model grid may be necessary to accurately simulate the aflaj (Mack and Eggleston, 2015).

\section{Sensitivity Analysis and Model Parameters}

A sensitivity analysis of the parameters in the predevelopment groundwater flow model (scenario 1) was performed during the calibration process using UCODE_2014 with the datasets, statistics, and weights described above. Figure $18 A$ shows the relative sensitivity of model parameters and contribution by observation group, indicated by CSS with a dimensionless rank of 0 to 1 , in the predevelopment model (scenario 1). Parameter sensitivities depend on the observation data, parameter values, and conceptualization of the groundwater flow system. Other conceptualizations, or different observation data, could result in different sensitivities. For this reason, several scenarios were included in this study to enable examination of the significance and effects of variations in the recharge components (table 4) estimated by Osterkamp and others (1995) on the groundwater flow system and the effect on estimation of other parametersprimarily hydraulic conductivities. In scenario 1 , the base scenario, piedmont, gap, wadi, and mountain-front recharge were applied as originally estimated by Osterkamp and others (1995). In scenario 2, piedmont recharge was also applied as originally estimated, at 1 percent of precipitation, but gap, wadi, and mountain-front recharge were then optimized in UCODE_2014 and allowed to vary by up to 50 percent of their original values. In scenario 3 , piedmont recharge was set at 3.4 percent of precipitation, selected as an upper limit on the basis of previous investigations in the study area and in similar settings elsewhere (see "Recharge" section), and gap, wadi, and mountain-front recharge were applied as originally estimated. In scenario 4 , piedmont recharge was again set at 3.4 percent of precipitation, but in this scenario, gap, wadi, and mountain-front recharge were then optimized in UCODE_2014 and allowed to vary by up to 50 percent of their original values. For these four scenarios, hydraulic conductivity parameters were estimated with UCODE as described previously in "Model Calibration."

The parameter sensitivity graphs (fig. 18) show the relative sensitivity of the flow system to the horizontal hydraulic conductivities and boundary conditions in each scenario. Vertical conductivities were not explicitly assessed because of their low sensitivity in the predevelopment model, which can be expected without simulated groundwater withdrawals at depth. However, vertical hydraulic conductivities were included in the analysis in that they were linked to the assessed horizontal hydraulic conductivities. Parameters not included in the sensitivity analysis were hydraulic conductivities representing water in the Arabian Gulf, which was simply set at a high value $(1,000 \mathrm{~m} / \mathrm{d})$, and the constant head at the western model boundary, which was set at elevation of $0 \mathrm{~m}$. For all scenarios, a dominant parameter was gap recharge (TRLSAG; fig. 18A). Other parameters with relative significance included hydraulic conductivity of sediments mapped as fluvial sediments (HK_Fluv), dune (HK_Dune), and desert plain (HK_Plain). This is understandable given that these sediments cover large areas of the model (fig. 2). Parameters for desert plain and 
$56^{\circ}$

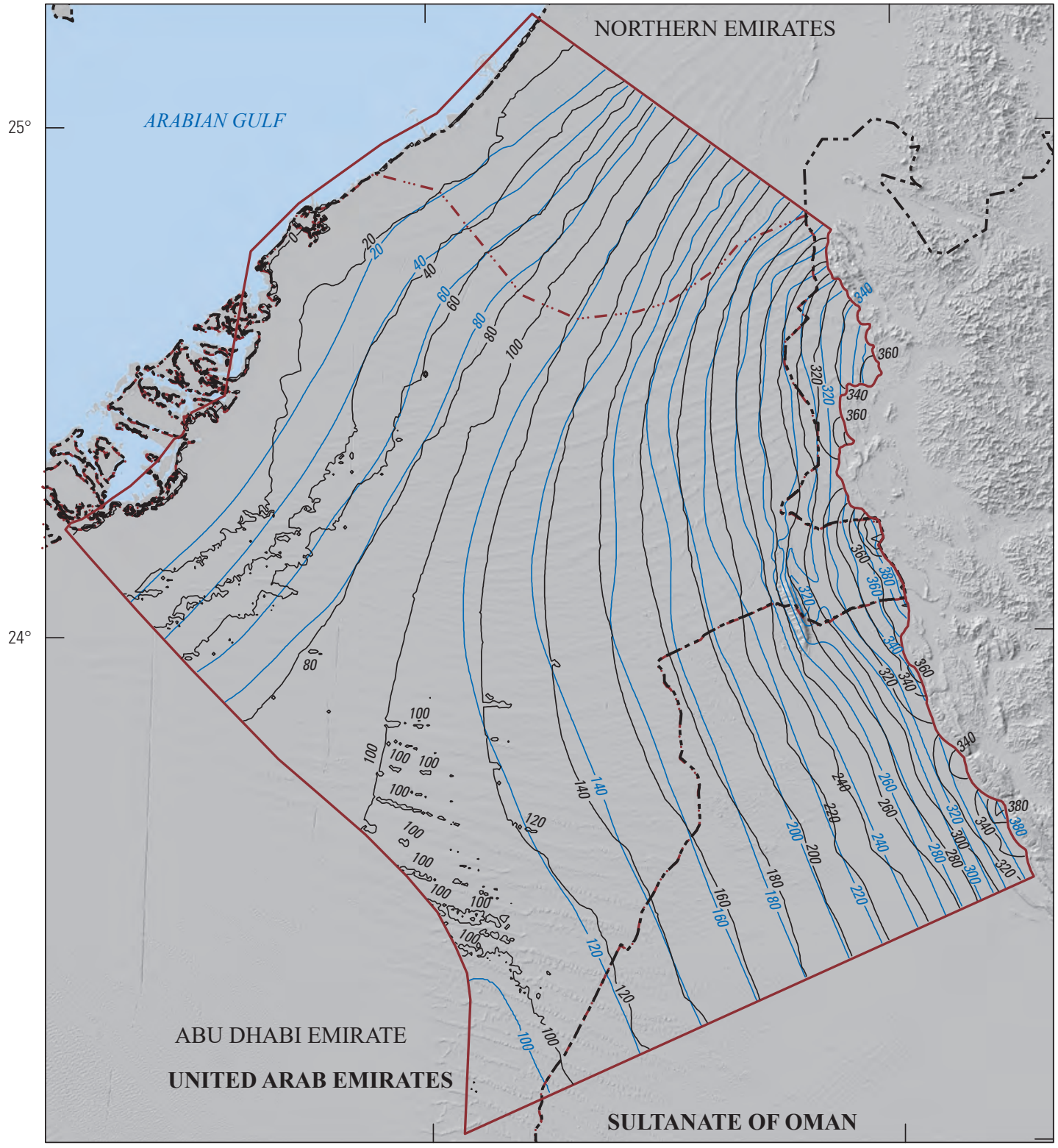

Base from ASTER Global Digital Elevation Model

Version 2., 2009, 30-meter shaded relief

World Geodetic System of 1984/Earth Gravitational Model 1996

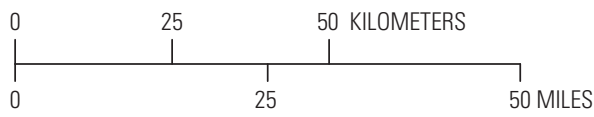

\section{EXPLANATION}

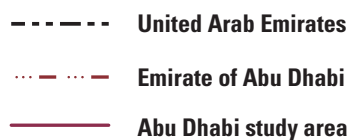

Simulated predevelopment groundwater head contour, in meters above sea levelContour interval is 20 meters

Predevelopment groundwater head contour in meters above sea level-Modified from Imes and Clark (2006). Contour interval is 20 meters

Figure 17. Simulated predevelopment groundwater contours and contours interpreted from Imes and Clark (2006), eastern Emirate of Abu Dhabi, United Arab Emirates. 

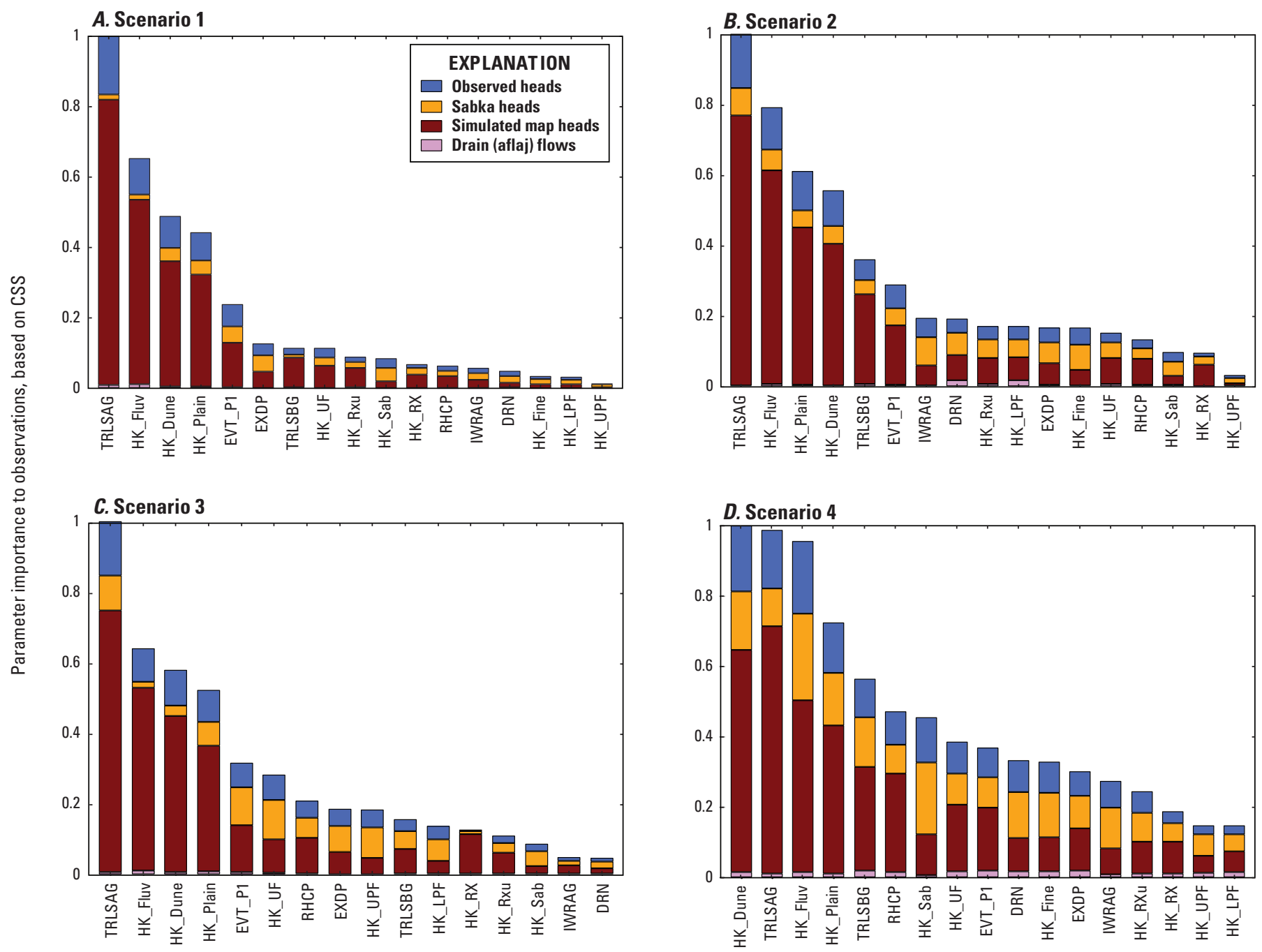

Parameter names

Figure 18. Ranked parameter sensitivities (composite scaled sensitivities [CSS]; dimensionless), showing contributions from different observation groups, for model parameters for four groundwater flow model scenarios, predevelopment groundwater flow model of the eastern Emirate of Abu Dhabi, United Arab Emirates. A, Scenario 1-all recharge components set at values estimated by 0sterkamp and others (1995). B, Scenario 2-piedmont recharge set at 1 percent of precipitation, as estimated by Osterkamp and others (1995), and mountain-front, gap, and wadi recharge components optimized by up to 50 percent of the values estimated by Osterkamp and others (1995). C, Scenario 3-Piedmont recharge set at 3.4 percent of precipitation, and mountain-front, gap, and wadi recharge components set at values estimated by 0sterkamp and others (1995). D, Scenario 4-Piedmont recharge set at 3.4 percent of precipitation, and mountain-front, gap, and wadi recharge components optimized by up to 50 percent of the values estimated by Osterkamp and others (1995). Parameters are listed in table 4. 
fluvial sediments are relatively sensitive, probably because they are in the eastern areas of the model where recharge fluxes occur. The other recharge parameters, piedmont (RHCP), wadi (TRLSBG), and mountain-front recharge (IWRAG), were generally more sensitive than other parameters in the model, but not uniformly so. The importance of the recharge parameters, in terms of sensitivity, indicates the need to improve the understanding of recharge magnitudes. The ET parameter was also a more sensitive factor in the flow system than many other parameters, which is understandable because it controls the largest flux out of the model. The predevelopment model was less sensitive to subsurface hydrogeologic parameters (HK_UF, HK_UPF, HK_LPF). This is also understandable given that in the predevelopment scenario, with no withdrawals at depth, there is little flow in the deeper portions of the model. In the future, if groundwater withdrawals occur in these areas, the sensitivity distribution would be different. The relative contributions of the different observation datasets are also apparent in figure 18. For example, the parameters concentrated where the calibration heads are clustered, such as wadi recharge (TRLSBG) and fluvial sediments (HK_Fluv), are influenced to a large degree by the calibration head data. The sensitivity analysis also revealed that selected model parameters, such as the hydraulic conductivity of fluvial sediment (HK_Fluv) and gap recharge (TRLSAG), were highly correlated ( $r$ squared value of 0.90 or more) for the four scenarios, and fluvial sediment, dune sediments, and gap recharge were also correlated for some scenarios, indicating that models with various ratios of these parameters might result in similar calculated heads.

Parameter estimates were assessed by using 95-percent confidence intervals (fig. 19) calculated by using UCODE_2014 (Poeter and others, 2014). Estimated hydraulic conductivities were within ranges described in the "Hydraulic Conductivity" section of the report. Localized areas of high hydraulic conductivity were not specifically simulated because doing so would require further hydraulic conductivity characterization in three dimensions. Confidence intervals for parameters in the four predevelopment groundwater model scenarios give further insight into the understanding of model parameters and conceptual scenarios. Large confidence intervals indicate low confidence in the parameter values or that parameter values are not well known, whereas small confidence intervals indicate high confidence in the parameter values or that these values are well known. Similar to parameter sensitivities (fig. 18), the confidence intervals are a result of the observation data, parameter values (table 4), and conceptualization of the groundwater flow system.

Parameters with large confidence intervals (fig. 19), shown by plots of the parameter values divided by the values in the 95-percent confidence range, included the lower postFars (HK_LPF), upper post-Fars (HK_UPF), fine-grained sediments (HK_Fine), aflaj or drain conductance (DRN), and gap recharge (IWRAG). The fine-grained sediments (HK_Fine) parameter was generally not sensitive in the model and was set at $2.0 \mathrm{~m} / \mathrm{d}$. The large confidence interval is understandable because there are few or no observation points in fine-sediment areas and there is likely to be little groundwater flow in these areas. The large confidence intervals for upper and lower post-Fars hydraulic conductivity result both from the small number of observations and the low groundwater flow in these units. The large confidence intervals for the recharge parameters, particularly gap recharge (IWRAG), one of the most sensitive parameters in the scenarios assessed, indicates that this recharge, although important in the overall flow system, is still not well known. Parameter confidence intervals are smaller (improved) in the scenarios where gap, wadi, and mountain-front recharge were optimized by up to 50 percent of original base values. With limited optimization of recharge components (scenarios 2 and 4), gap and mountain-front recharge decrease by about 50 percent and wadi recharge increases by 50 percent of base scenario rates. The similarity of the magnitude and direction of optimized rates for different scenarios indicates that actual recharge rates are not well known. In particular, gap and mountain-front recharge may be less than estimated rates, and wadi recharge may be greater than previously estimated rates.

The effect of variations in recharge components on the water balance (table 5) stands out in the comparison of scenarios 2 and 3. Scenario 2 had the lowest total flow, about 36 percent less than the base scenario, and scenario 3 had the greatest total flow, about 26 percent greater than the base scenario. None of the scenarios reproduced the aflaj flows well, as all simulations underestimated aflaj flows by 75 percent or more. A number of factors may explain these underestimates, including the geometry of drain elevations simulating aflaj and the possibility that current (2016) mean precipitation is different than precipitation of earlier decades when the aflaj flow measurements were made. However, simulations that better fitted aflaj flows (not shown) required gap and wadi recharge to be an order of magnitude greater than the previously estimated base scenario rates.

The good fit between simulated and observed predevelopment regional heads in the base scenario (fig. 17) indicates the model is useful for analysis of predevelopment recharge conditions in the study area and for investigation of regional patterns of groundwater flow. Model sensitivity results reveal a need for data that more thoroughly and more accurately describe aquifer hydraulic conductivity, inflow to the aquifer from the Oman Mountains, and recharge from precipitation on the piedmont. Additional long-term aquifer pumping test observations would improve understanding of aquifer hydraulic conductivity, which would also improve model accuracy. 

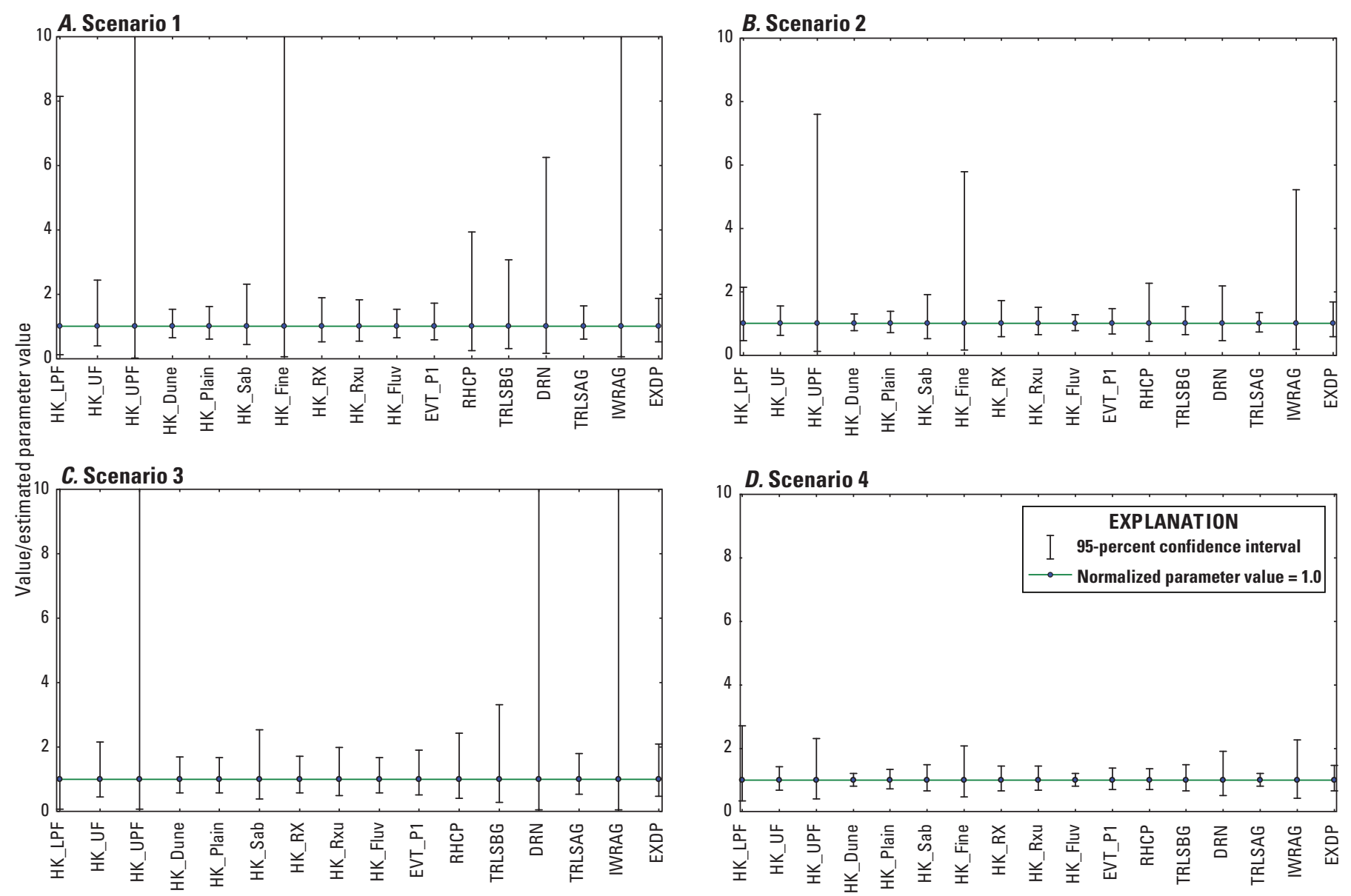

Parameter name

Figure 19. 95-percent confidence intervals for normalized parameter estimates for four groundwater flow model scenarios, predevelopment groundwater flow model of the eastern Emirate of Abu Dhabi, United Arab Emirates. A, Scenario 1—all recharge components set at values estimated by Osterkamp and others (1995). B, Scenario 2-piedmont recharge set at 1 percent of precipitation, as estimated by Osterkamp and others (1995), and mountain-front, gap, and wadi recharge components optimized by up to 50 percent of the values estimated by Osterkamp and others (1995). C, Scenario 3-Piedmont recharge set at 3.4 percent of precipitation, and mountain-front, gap, and wadi recharge components set at values estimated by 0sterkamp and others (1995). $D$, Scenario 4-Piedmont recharge set at 3.4 percent of precipitation, and mountain-front, gap, and wadi recharge components optimized by up to 50 percent of the values estimated by Osterkamp and others (1995). Parameters are listed in table 4. 
$\left[\mathrm{m}^{3} / \mathrm{d}\right.$, cubic meter per day; $\mathrm{m}$, meter; --, not applicable]

\begin{tabular}{|c|c|c|c|c|c|c|c|c|c|c|}
\hline \multirow{4}{*}{ Simulated flux } & \multicolumn{2}{|l|}{ MODFLOW-2005 } & \multicolumn{2}{|c|}{ Scenario 1-base } & \multicolumn{2}{|c|}{ Scenario 2} & \multicolumn{2}{|c|}{ Scenario 3} & \multicolumn{2}{|c|}{ Scenario 4} \\
\hline & \multirow{3}{*}{ Model package } & \multirow{3}{*}{$\begin{array}{l}\text { Model } \\
\text { parame- } \\
\text { ter name }\end{array}$} & \multicolumn{4}{|c|}{ Piedmont recharge, 1 percent of precipitation } & \multicolumn{4}{|c|}{ Piedmont recharge, 3.4 percent of precipitation } \\
\hline & & & \multicolumn{2}{|c|}{$\begin{array}{l}\text { Mountain-front, gap, and } \\
\text { wadi recharge set at } \\
\text { Osterkamp rates }{ }^{1}\end{array}$} & \multicolumn{2}{|c|}{$\begin{array}{l}\text { Mountain-front, gap, and } \\
\text { wadi recharge optimized } \\
\text { up to } 50 \text { percent of } \\
\text { Osterkamp rates }{ }^{1}\end{array}$} & \multicolumn{2}{|c|}{$\begin{array}{l}\text { Mountain-front, gap, and } \\
\text { wadi recharge set at } \\
\text { Osterkamp rates }\end{array}$} & \multicolumn{2}{|c|}{$\begin{array}{c}\text { Mountain-front, gap, and } \\
\text { wadi recharge optimized } \\
\text { up to } 50 \text { percent of } \\
\text { Osterkamp rates }{ }^{1}\end{array}$} \\
\hline & & & $\begin{array}{l}\text { Inflow or } \\
\text { outflow } \\
\left(\mathrm{m}^{3} / \mathrm{d}\right)\end{array}$ & $\begin{array}{l}\text { Percent } \\
\text { of total } \\
\text { inflow or } \\
\text { outflow }\end{array}$ & $\begin{array}{l}\text { Inflow or } \\
\text { outflow } \\
\left(\mathrm{m}^{3} / \mathrm{d}\right)\end{array}$ & $\begin{array}{l}\text { Percent } \\
\text { of total } \\
\text { inflow or } \\
\text { outflow }\end{array}$ & $\begin{array}{l}\text { Inflow or } \\
\text { outflow } \\
\left(\mathrm{m}^{3} / \mathrm{d}\right)\end{array}$ & $\begin{array}{l}\text { Percent } \\
\text { of total } \\
\text { inflow or } \\
\text { outflow }\end{array}$ & $\begin{array}{l}\text { Inflow or } \\
\text { outflow } \\
\left(\mathrm{m}^{3} / \mathrm{d}\right)\end{array}$ & $\begin{array}{c}\text { Percent } \\
\text { of total } \\
\text { inflow or } \\
\text { outflow }\end{array}$ \\
\hline \multicolumn{11}{|c|}{ Inflow } \\
\hline Mountain-front recharge & WELL & IWRAG & 2,508 & 1.7 & 1,329 & 1.4 & 2,508 & 1.3 & 1,655 & 1.3 \\
\hline Gap recharge & WELL & TRLSAG & 119,474 & 80.0 & 60,934 & 64.2 & 119,474 & 63.3 & 59,738 & 45.3 \\
\hline Wadi recharge & WELL & TRLSBG & 10,176 & 6.8 & 15,264 & 16.1 & 10,230 & 5.4 & 15,264 & 11.6 \\
\hline Piedmont recharge & RECHARGE & RHCP & 15,570 & 10.4 & 15,570 & 16.4 & 52,938 & 28.1 & 52,938 & 40.1 \\
\hline Flux with gulf & CONSTANT HEAD & CHD & 1,675 & 1.1 & 1,823 & 1.9 & 3,470 & 1.8 & 2,315 & 1.8 \\
\hline Total inflow & & & 149,403 & 100.0 & 94,920 & 100.0 & 188,620 & 100.0 & 131,910 & 100.0 \\
\hline \multicolumn{11}{|c|}{ Outflow } \\
\hline Flux with gulf & CONSTANT HEAD & CHD & 2,204 & 1.5 & 1,186 & 1.2 & 1,910 & 1.0 & 1,309 & 1.0 \\
\hline Aflaj & DRN & DRN & 9,020 & 6.0 & 5,704 & 6.0 & 9,306 & 4.8 & 6,277 & 4.8 \\
\hline Evapotranspiration & EVT & EVT_P1 & 138,250 & 92.5 & 88,175 & 92.1 & 180,740 & 94.2 & 123,634 & 94.2 \\
\hline Total outflow & & & 149,474 & 100.0 & 95,065 & 99.3 & 191,956 & 100.0 & 131,220 & 100.0 \\
\hline Net simulated flow to gulf & & & -529 & -0.4 & 637 & 0.7 & 1,560 & 0.8 & 1,006 & 0.8 \\
\hline \multicolumn{3}{|c|}{ Model standard error (m) } & 5.92 & -- & 5.71 & -- & 6.1 & -- & 5.48 & -- \\
\hline Model fit & $\begin{array}{l}\text { Average weighted } \\
\text { residual }(\mathrm{m})\end{array}$ & & 0.50 & -- & 1.05 & -- & 1.76 & -- & 0.99 & -- \\
\hline
\end{tabular}

${ }^{1}$ Recharge rates provided in table 3, modified from Osterkamp and others (1995). 


\section{Simulation of Predevelopment Groundwater Flow}

A regional water balance for the eastern Abu Dhabi aquifer was calculated for scenario 1, the base scenario model. Components of the water balance are provided in table 5 for the four scenarios described previously. With respect to total simulated inflows to the aquifer, the base scenario flow value was 149,403 cubic meters per day $\left(\mathrm{m}^{3} / \mathrm{d}\right)$, the lowest flow value was $94,920 \mathrm{~m}^{3} / \mathrm{d}$ for scenario 2 , and the highest flow value was $188,620 \mathrm{~m}^{3} / \mathrm{d}$ for scenario 3 . In the base scenario, gap recharge represents 80 percent of total inflow $(119,470$ of 149,403 cubic meters per day). The remaining inflows to the aquifer are from piedmont recharge (10 percent), wadi recharge ( 7 percent), and mountain-front recharge ( 2 percent). The greatest outflow from the aquifer is from evapotranspiration (93 percent of total outflow in the base scenario). Aflaj outflows represent about 6 percent of the total water balance $\left(9,020\right.$ of $\left.149,400 \mathrm{~m}^{3} / \mathrm{d}\right)$ in the base scenario.

Simulated head contours in the base scenario (fig. 17) show higher heads in the east, where most recharge occurs, and heads decreasing to the west, where topography flattens out to sea level along the coast. The overall water-level distributions are similar to previously mapped water-level contours (for example, Imes and Clark, 2006). The effect of evaporation on shallow groundwater levels is seen in the southwestern parts of the model, where contours show detailed water-level variations corresponding to dune topography, presumably caused by evaporation of groundwater and correspondingly lower water levels in low areas between dunes.

\section{Model Scenarios and Effects of Different Recharge Components}

The four different scenarios had different amounts of recharge for the primary components: mountain-front, gap, and wadi recharge (fig. 18; table 5). Discharge to the gulf was calculated as the net simulated inflow minus outflow (table 5; negative is a flow from the aquifer to the gulf). Although localized chemical and isotopic analysis (Wood and others, 2002) has indicated that ET may capture nearly all groundwater flow out of the system, the actual discharge is unknown and can only be approximated. The base scenario model (scenario 1) simulates a small net outflow from the aquifer to the gulf $\left(-529 \mathrm{~m}^{3} / \mathrm{d}\right)$, an amount equal to only about 0.4 percent of the total budget. In scenarios 2 through 4 , a net inflow from the gulf to the aquifer was simulated but in all cases was still less than 1 percent of the total budget. In scenario 2, piedmont recharge was the same as in scenario 1, and total recharge from the mountain front, gap, and wadi was less than in scenario 1 . In scenario 3 , piedmont recharge was greater than in scenario 1, and mountain-front, gap, and wadi recharge were the same as in scenario 1 or were similar. In scenario 4, piedmont recharge was greater, mountain-front and gap recharge were smaller, and wadi recharge was greater than in scenario 1.

\section{Model Assumptions and Limitations}

The groundwater model of the Abu Dhabi eastern region study area provides a regional-scale simulation of groundwater flow and water balance but is not intended for site-specific analysis. A groundwater flow model is a numerical representation of the physical flow system and inherently requires numerous assumptions and simplifications. Limitations are inherent in the practical application of groundwater flow models, and the assumptions and simplifications incorporated in a model depend on the intended use of that model. For example, the Abu Dhabi model does not simulate unsaturated-zone flow processes (groundwater flow above the water table), and the steady-state predevelopment scenario requires a simplifying assumption of uniform, constant conditions with time. Other model simplifications include the parameterization of hydrogeologic properties and characteristics into homogenous units (a process dependent on geologic maps and limited borings) and the assignment of these parameters to groups of cells with areas of $500 \mathrm{~m}$ by $500 \mathrm{~m}$. Simplification also includes the temporal averaging of recharge and reliance on water-level observations from different times. Limitations are reflected by large 95-percent confidence intervals (fig. 19) calculated for model parameters representing lower post-Fars and upper post-Fars hydrogeologic units, fine-grained sediments, and aflaj or drain conductance. Additionally, high correlations between hydraulic conductivity in fluvial sediment and gap recharge indicate a non-unique solution to the optimization problem (another set of model parameters could provide just as a good a match between simulated and observed heads as the optimal parameters reported here). Therefore, it is likely that greater confidence in the model's simulated head could be obtained by future collection of better observations to constrain estimates of gap recharge and recalibration of the model. However, the base simulation results can be considered to provide a general representation of probable predevelopment groundwater flow conditions. The model is not intended for use at the local scale or for inferences of conditions after 1980.

Model scenario and sensitivity results reveal a need for data that more thoroughly and more accurately describe aquifer hydraulic conductivity, inflow to the aquifer from the Oman Mountains, and recharge from precipitation on the piedmont. Additional long-term aquifer pumping test observations would improve understanding of aquifer hydraulic conductivity, which would also improve model accuracy. Future studies can modify the model to understand the effect of land-use change and water use on groundwater supplies and simulate more complex groundwater flow conditions in a predictive mode. 


\section{Summary and Conclusions}

Predevelopment groundwater conditions in eastern Abu Dhabi were assessed and estimated between 2015 and 2016 through a cooperative investigation between the U.S. Geological Survey and the Environment Agency-Abu Dhabi. The investigation was completed by developing groundwater flow models for a 27,000 -square-kilometer area of the eastern region of Abu Dhabi to provide insight into predevelopment recharge, discharge, and general groundwater flow conditions. In undertaking this investigation, a secondary objective was to assess the data available for detailed assessments of current and future groundwater conditions. Understanding predevelopment groundwater conditions and fluxes, from when there were almost no groundwater withdrawals compared to current (2016) use, is a necessary step prior to investigating modern conditions or predicting future conditions.

Components of the predevelopment groundwater flow system were assessed by developing and calibrating a preliminary steady-state model of long-term average conditions. This investigation reexamined existing borehole log, geophysical, and aquifer-test data to refine the understanding of hydrogeologic units and hydraulic characteristics in the study area. This investigation considered hydrogeologic units-the Upper Fars Formation, lower post-Fars, and upper post-Fars units - not previously assessed in groundwater flow simulations. Historical groundwater-level data and records of aflaj flow were compiled to provide observations of groundwater levels and limited discharge. Finite-difference groundwater flow models were constructed by using MODFLOW-2005 groundwater flow software and UCODE_2014 software for parameter estimation and sensitivity testing. The models consisted of five layers. The upper two model layers represent the surficial sediments, including fluvial, alluvial, desert plain, sabkha, and dune sediments, and other minor sediments. The lower three model layers represent generally less permeable interlayered sand and mudstones and siltstones. Layer 3 represents, primarily, sediments of the upper post-Fars (UPF) hydrogeologic unit, up to 47 meters (m) thick where UPF is present and $8 \mathrm{~m}$ thick elsewhere. Layer 4 represents, primarily, the sediments of the lower post-Fars (LPF) hydrogeologic unit, up to $224 \mathrm{~m}$ thick where LPF is present and $16 \mathrm{~m}$ thick elsewhere. Layer 5 represents, primarily, the sediments of the Upper Fars (UF) hydrogeologic unit and is generally about 200 to $300 \mathrm{~m}$ thick and at least $32 \mathrm{~m}$ thick. The groundwater model developed in this investigation differs from those of previous investigations in that the lower hydrogeologic units (UPF, LPF, and UF), generally finer grained sediments than those in the surficial aquifer, were simulated, and parameter estimation techniques were used to provide a statistically thorough analysis of model parameters and results.

The investigation developed a base simulation scenario for which the recharge components previously estimated for the study area were used as model input. The recharge components were categorized and simulated as four processes: piedmont recharge, infiltration from precipitation on coarse-grained sediments in selected areas; gap recharge, lateral groundwater inflow through wadi alluvium upgradient of the eastern model boundary; wadi recharge, infiltration of surface runoff in wadi courses; and mountain-front recharge, lateral inflow through bedrock along the eastern model boundary. Hydraulic conductivities and some boundary conditions, such as evapotranspiration, were estimated with parameter estimation techniques. Observations of groundwater levels (heads) for 1,342 sites were compiled through a combination of water-level measurements at wells in the study area that were judged to be free of development effects; water levels obtained from a predevelopment water-level map from a previous investigation; and water levels estimated from sabkha surface elevations. Observations of flow were provided by historical measured and estimated falaj flows at 13 locations.

Model scenarios were developed and simulated to assess recharge components. Several variations on the base scenario, in which piedmont recharge was held fixed at two levels in a realistic range, and the other three recharge components were optimized by using parameter estimation (UCODE_2014) by up to 50 percent of the base scenario values. Including the base scenario, this resulted in a total of four scenarios. The base scenario provided the best fit to head observations with a mean residual between observed and simulated heads of $0.5 \mathrm{~m}$. However, the mean head residuals for the other scenarios were 1 to $1.8 \mathrm{~m}$, and these might also be realistic scenarios. In all scenarios, errors were greater and less well distributed toward the eastern model boundary where hydrogeologic units were more complex, which indicates a need for a better definition of hydraulic characteristics in eastern areas of the model. In terms of simulating observed fluxes, none of the four scenarios simulated historical falaj flows well, and all four underestimated flows by 75 percent or more. The falaj flows were not a major component in the simulated water balance, representing only about 6 percent of the total water balance in the base scenario. Most of the flow underestimation is likely due to poor knowledge of falaj geometry for simulation in the model, and therefore little effort was made to improve the falaj simulation. Alternate explanations include underestimation of inflows to the aquifer or modern-day inflows to the aquifer being less than historic inflows. Precipitation for the predevelopment period and earlier might have been greater than the mean annual precipitation since 1975, which could contribute to simulated falaj flows being smaller than measured falaj flows.

Model results and sensitivity analyses indicated that recharge fluxes in the study area are not well understood. With respect to simulated inflows to the aquifer, the base scenario flow value was 149,403 cubic meters per day $\left(\mathrm{m}^{3} / \mathrm{d}\right)$, the lowest flow value was $94,920 \mathrm{~m}^{3} / \mathrm{d}$ (scenario 2), and the highest flow value was $188,620 \mathrm{~m}^{3} / \mathrm{d}$ (scenario 3). These total inflow values are all possible, and the model does not allow us to distinguish which is most likely. This range in simulated water balances indicates that the magnitudes of the various recharge fluxes in the study area are not well understood. Correspondingly, evapotranspiration is calculated as an end product in 
the groundwater flow simulation, and the range in magnitude of this flux is similar to that of the recharge components. Although several local-scale investigations into these fluxes have been undertaken in the study area, there are no definitive regional-scale investigations necessary to constrain estimates of recharge and evapotranspiration in the study area. The implications of a poor understanding of recharge components are that some hydraulic parameters in the model are highly correlated - for example the fluvial sediment hydraulic conductivity (HK_Fluv) was found to be highly correlated (approximately 90 percent or more) with gap recharge - and various ratios of these characteristics would yield similar model results in terms of simulated heads.

The groundwater flow model developed in this investigation and the analysis of borehole logs and geophysical data provide an improved understanding of the predevelopment groundwater flow conditions in the eastern region of the Emirate of Abu Dhabi. The investigation finds that although there are a large number of groundwater-level observations, there are few observations of flow or discharges necessary to constrain estimates of recharge and evapotranspiration that account for more than 90 percent of the total balance of inflows and outflows. Because each of the major components of the water balance is poorly constrained (or not quantified with more certainty), the hydraulic characteristics of the groundwater flow system are therefore not well constrained because of correlations between specific sediments and recharge components in the flow system. Future studies can narrow the range of possible total recharge and hence of available groundwater supplies. Future studies can also modify the model to understand the effect of land-use change and water use on groundwater supplies and simulate more complex groundwater flow conditions in a predictive mode.

\section{References Cited}

[Administrative reports authored by the National Drilling Company, the National Drilling Company-U.S. Geological Survey, and the U.S. Geological Survey for the National Drilling Company are available by request through the Environment Agency—Abu Dhabi (EAD), P.O. Box: 45553, Al Mamoura Building (A), Muroor Road, Abu Dhabi, United Arab Emirates, Tel: +971 2 445 4777, https://www.ead.ae/SitePages/home.aspx]

ASTER GDEM Validation Team, 2011, ASTER Global Digital Elevation Model version 2-Summary of validation results: National Aeronautics and Space Administration Land Processes Distributed Active Archive Center, 26 p., accessed January 1, 2017, at http://www.jspacesystems.or.jp/ersdac/ GDEM/ver2Validation/Summary_GDEM2_validation_ report_final.pdf.
Barlow, P.M., and Moench, A.F., 1999, WTAQ-A computer program for calculating drawdowns and estimating hydraulic properties for confined and water-table aquifers: U.S. Geological Survey Water-Resources Investigations Report 99-4225, $74 \mathrm{p}$.

Besler, B., 1982, The north-eastern Rub Al Khali within the borders of the United Arab Emirates: Zeitschrift für Geomorphologie, v. 26, no. 4, p. 495-504.

Brook, M., 2006, Water resources of Abu Dhabi Emirate, U.A.E. Environment Agency Abu Dhabi: United Arab Emirates, Water Resources Department, $167 \mathrm{p}$.

Brook, M., and Al Houqani, H., 2006, Current status of aflaj in the $\mathrm{Al}$ Ain area, United Arab Emirates: United Arab Emirates, Environment Agency-Abu Dhabi, 27 p.

Consultants for Water and Environment and Bin Ham Well Drilling Establishment, 1986a, Ground water study, project 21/81 - Drilling of deep water wells at various locations in the U.A.E.- Main report: United Arab Emirates, Ministry of Agriculture and Fisheries, Water and Soil Department, v. $1,214 \mathrm{p}$.

Consultants for Water and Environment and Bin Ham Well Drilling Establishment, 1986b, Ground water study, project 21/81 - Drilling of deep water wells at various locations in the U.A.E.-Maps and plates: United Arab Emirates, Ministry of Agriculture and Fisheries, Water and Soil Department, v. 2, 14 maps, 2 pls.

Consultants for Water and Environment and Bin Ham Well Drilling Establishment, 1986c, Ground water study, project 21/81-Drilling of deep water wells at various locations in the U.A.E.- Geophysical surface measurements: United Arab Emirates, Ministry of Agriculture and Fisheries, Water and Soil Department, v. 3, 19 p., 4 maps.

Consultants for Water and Environment and Bin Ham Well Drilling Establishment, 1986d, Ground water study, project 21/81 - Drilling of deep water wells at various locations in the U.A.E.-Basic data of project wells: United Arab Emirates, Ministry of Agriculture and Fisheries, Water and Soil Department, v. 4, 9 p.

Consultants for Water and Environment and Bin Ham Well Drilling Establishment, 1986e, Ground water study, project 21/81 - Drilling of deep water wells at various locations in the U.A.E.-Groundwater development in the western agricultural region: United Arab Emirates, Ministry of Agriculture and Fisheries, Water and Soil Department, v. 5, 58 p.

Cooper, H.H., Jr., and Jacob, C.E., 1946, A generalized graphical method for evaluating formation constants and summarizing well field history: Transactions, American Geophysical Union., v. 27, no. 4, p. 526-534. [Also available at https://doi.org/10.1029/TR027i004p00526.] 
Czarnecki, J.B., Sanford, W.E., and Wood W.W., 1999, Brine resources in coastal sabkhas of Abu Dhabi, United Arab Emirates: National Drilling Company-U.S. Geological Survey administrative report for Emirate of Abu Dhabi, Abu Dhabi National Oil Company. [Available through the Environment Agency_Abu Dhabi.]

de Marsily, G., 1986, Quantitative hydrogeology—Groundwater hydrology for engineers: San Diego, Academic Press, $440 \mathrm{p}$.

Dincer, T., Al-Mugrin, A., and Zimmermann, U., 1974, Study of the infiltration and recharge through sand dunes in arid zones with special reference to the stable isotopes and thermonuclear tritium: Journal of Hydrology (Amsterdam), v. 23, no. 1-2, p. 79-109. [Also available at https://doi.org/10.1016/0022-1694(74)90025-0.]

Farrant, A.R., Ellison, A.R., Thomas, R.J., Goodenough, K.M., and others, 2012, Geologic map of the United Arab Emirates: United Arab Emirates, Ministry of Energy, Department of Geology and Mineral Resources, and British Geological Survey, 1 sheet, scale 1:500,000.

Flint, L.E., and Flint, A.L., 2007, Regional analysis of groundwater recharge, in Stonestrom, D.A., Constantz, J., Ferre, T.P.A., and Leake, S.A., eds., Ground-water recharge in the arid and semiarid southwestern United States: U.S. Geological Survey Professional Paper 1703-B, p. 29-60, accessed January 2018 at http://pubs.usgs.gov/pp/pp1703/b/.

Food and Agriculture Organization, 2009, Global map of aridity: Food and Agriculture Organization GeoNetwork database, accessed February 18, 2020, at http://www.fao.org/ geonetwork/srv/en/main.home.

Freeze, R.A., and Cherry, J.A., 1979, Groundwater: Englewood Cliffs, N.J., Prentice-Hall, 604 p.

Garcia, C.A., Huntington, J.M., Buto, S.G., Moreo, M.T., Smith, J.L., and Andraski, B.J., 2015, Groundwater discharge by evapotranspiration, Dixie Valley, west-central Nevada, March 2009-September 2011 (ver. 1.1, April 2015): U.S. Geological Survey Professional Paper 1805, 90 p., accessed January 2018 at http://dx.doi.org/10.3133/ pp1805.

Geoconsult and Bin Ham Drilling Establishment, 1985a, project 21/81 - Drilling of deep water wells at various locations in the UAE, v. I, general part: United Arab Emirates, Ministry of Agriculture and Fisheries, Water and Soil Department, unpublished report on file at Ministry of Agriculture and Fisheries, Dubai, $131 \mathrm{p}$.
Geoconsult and Bin Ham Drilling Establishment, 1985b, project 21/81-Drilling of deep water wells at various locations in the UAE, v. II, gravel plains: United Arab Emirates, Ministry of Agriculture and Fisheries, Water and Soil Department, unpublished report on file at Ministry of Agriculture and Fisheries, Dubai, 103 p.

Geoconsult and Bin Ham Drilling Establishment, 1985c, project 21/81 - Drilling of deep water wells at various locations in the UAE, v. III, 1-Masfut, 2-Al Ain, 3-Al Wagan, 4-Medeisis, 5-Liwa: United Arab Emirates, Ministry of Agriculture and Fisheries, Water and Soil Department, unpublished report on file at Ministry of Agriculture and Fisheries, Dubai, 87 p.

Gibb, Sir Alexander and Partners, 1969, Water resources survey-Interim report: Government of Abu Dhabi, Department of Development and Public Works, 223 p.

Gibb, Sir Alexander and Partners, 1970a, Water resources survey-Supplement to interim report, sub-surface investigations in the Al Ain area: Government of Abu Dhabi, Department of Development and Public Works, 608 p.

Gibb, Sir Alexander and Partners, 1970b, Water resources survey-Final report: Government of Abu Dhabi, Department of Development and Public Works, 37 p., 5 appendixes.

Gillespie, J.B., and Mohamed, F.A., 2006 Environmental setting and geologic framework of Abu Dhabi Emirate, part II of Hutchinson, C.B., ed., Ground-water resources of Abu Dhabi Emirate: U.S. Geological Survey administrative report. [Available through the Environment Agency—Abu Dhabi.]

GTZ/Dornier Consult, 2005, Status report phases 1Xa, 1Xb and 1Xc for Groundwater Assessment Project Abu Dhabi: Consulting report to Abu Dhabi National Oil Company. [Available through the Environment Agency-Abu Dhabi.]

Halcrow, Sir William and Partners, 1969a, Report on the water resources of the Trucial States: Trucial States Council, Consultant Report, v. 1, 161 p.

Halcrow, Sir William and Partners, 1969b, Report on the water resources of the Trucial States: Trucial States Council, Water Resources Survey, v. 2, schedules, part 1, 256 p.

Halcrow, Sir William and Partners, 1969c, Report on the water resources of the Trucial States: Trucial States Council, Water Resources Survey, v. 2, schedules, part 2, 515 p.

Harbaugh, A.W., 2005, MODFLOW-2005, The U.S. Geological Survey modular ground-water model - the ground-water flow process: U.S. Geological Survey Techniques and Methods, book 6, chap. A16, variously paginated, accessed January 2018 at http://pubs.er.usgs.gov/usgspubs/tm/tm6A16. 
Hijmans, R.J., Cameron, S.E., Parra, J.L., Jones, P.G., and Jarvis, A., 2005. Very high resolution interpolated climate surfaces for global land areas: International Journal of Climatology, v. 25, no. 15, p. 1965-1978, accessed March 30, 2015, at http://worldclim.org/current/.

Hill, M.C., and Tiedeman, C.R., 2007, Effective groundwater model calibration-With analysis of data, sensitivities, predictions, and uncertainty: Hoboken, N.J., Wiley, 455 p. [Also available at https://doi.org/10.1002/0470041080.]

Hutchinson, C.B., ed., 2006, Ground-water resources of Abu Dhabi Emirate: National Drilling Company-U.S. Geological Survey administrative report, prepared for the National Drilling Company, Abu Dhabi, 136 p. [Available through the Environment Agency_Abu Dhabi.]

Hydroconsult, 1978, Reconnaissance report and development proposals, Abu Dhabi, (UAE) Eastern Region water resources: Government of Abu Dhabi, Ministry of Petroleum and Mineral Resources Report, 126 p.

Imes, J.L., 2012, Groundwater-level changes in the shallow aquifer from historical predevelopment conditions and 2005 conditions to 2010, Abu Dhabi Emirate, United Arab Emirates: National Drilling Company-U.S. Geological Survey Technical Series Administrative Report 2012-001, 26 p. [Available through the Environment Agency-Abu Dhabi.]

Imes, J.L., and Clark, D.W., 2006, Estimated pre-modern and 2005 volumes of useable groundwater, by water type, stored in the surficial aquifer of Abu Dhabi Emirate, United Arab Emirates: National Drilling Company-U.S. Geological Survey Technical Series Administrative Report 2006-001, 42 p. [Available through the Environment Agency-Abu Dhabi.]

Imes, J.L., and Clark, D.W., 2013, Estimated predevelopment, 1990, 2005, and 2010 groundwater volumes in the surficial aquifer and upper 50 meters of the underlying deep sediments in Abu Dhabi Emirate, United Arab Emirates: National Drilling Company-U.S. Geological Survey Technical Series Administrative Report 2013-003, 20 p. [Available through the Environment Agency-Abu Dhabi.]

Imes, J.L., Signor, D.C., Woodward, D.G., and Wood, W.W., 1993, Hydrology and water quality, in Maddy, D.V., ed., Ground-water resources of Al Ain area, Abu Dhabi Emirate: U.S. Geological Survey Administrative Report 93-001, prepared for the National Drilling Company, Abu Dhabi, p. 168-283. [Available through the Environment AgencyAbu Dhabi.]

Imes, J.L., and Tawfiq, I., 2009, Results of a long-term aquifer test conducted near Sweihan, Abu Dhabi Emirate, to assess the sustained yield capability of the shallow aquifer: National Drilling Company-U.S. Geological Survey Technical Series Administrative Report 2009-002. [Available through the Environment Agency-Abu Dhabi.]
Imes, J.L., and Wood, W.W., 2007, Solute and isotope constraint of groundwater recharge simulation in an arid environment, Abu Dhabi Emirate, United Arab Emirates: Hydrogeology Journal, v. 15, no. 7, p. 1307-1315. [Also available at https://doi.org/10.1007/s10040-007-0177-x.]

Jorgensen, D.G., and al-Tikiriti, W.Y., 2003, A hydrologic and archeologic study of climate change in Al Ain, United Arab Emirates: Global and Planetary Change, v. 35, no. 1-2, p. 37-49. [Also available at https://doi.org/10.1016/S09218181(02)00090-5.]

Knisel, W.G., ed., 1980, CREAMS - A field scale model for chemicals, runoff, and erosion from agricultural management system: U.S. Department of Agriculture Conservation Research Report 26, 640 p.

Lane, L.J., 1982, Distributed model for small semiarid watersheds: Journal of the Hydraulics Division, v. 108, p. 1114-1131.

Mack, T.J., and Eggleston, J., 2015, Use of historic Persian water system data to calibrate groundwater models-Examples from Afghanistan and Emirates, in Maxwell, R., Hill, M., Zheng, C., and Tonkin, M., eds., MODFLOW and more 2015-Modeling a complex world [proceedings]: Golden, Colo., Colorado School of Mines Integrated Groundwater Modeling Center, p. 403-406.

Mack, T.J., Eggleston, J.R., Imes, J.L., Kress, W., Woodward, D.W., and Bright, D.J., 2020, MODFLOW-2005 groundwater flow model to simulate predevelopment groundwater flow in the eastern Abu Dhabi Emirate, United Arab Emirates: U.S. Geological Survey data release, https://doi.org/10.5066/P9ZWZISB.

Maddy, D.V., ed., 1993, Ground-water resources of Al Ain area, Abu Dhabi Emirate: U.S. Geological Survey Administrative Report 93-001, prepared for the National Drilling Company, Abu Dhabi, p. 14-17. [Available through the Environment Agency-Abu Dhabi.]

McDonald, M.G., and Harbaugh, A.W., 1988, A modular three-dimensional finite-difference ground-water flow model: U.S. Geological Survey Techniques of WaterResources Investigations, book 6, chap. A1, 586 p.

Menges, C.M., Hadley, D.G., Woodward, D.G., and Mohamed, F.A., 1993, Geology and geophysics, in Maddy, D.V., ed., Ground-water resources of Al Ain area, Abu Dhabi Emirate: U.S. Geological Survey Administrative Report 93-001, p. 74-167, prepared for the National Drilling Company, Abu Dhabi. [Available through the Environment Agency_Abu Dhabi.]

Moench, A.F., 1985, Transient flow to a large-diameter well in an aquifer with storative semiconfining layers: Water Resources Research, v. 21, no. 8, p. 1121-1131. [Also available at https://doi.org/10.1029/WR021i008p01121.] 
Moench, A.F., 1997, Flow to a well of finite diameter in a homogeneous, anisotropic water-table aquifer: Water Resources Research, v. 33, no. 6, p. 1397-1407. [Also available at https://doi.org/10.1029/97WR00651.]

Moreland, J.A., Clark, D.W., and Imes, J.L., 2007, Ground water-Abu Dhabi's hidden treasure: National Drilling Company-U.S. Geological Survey Technical Series Administrative Report 2007-001, 211 p. [Available through the Environment Agency_Abu Dhabi.]

National Center of Meteorology and Seismology, 2016, Mean monthly precipitation records: UAE National Center of Meteorology and Seismology website, accessed January 2016 at http://www.ncms.ae/.

National Drilling Company, 1992, Crop water requirements in Eastern Region, Abu Dhabi Emirate, UAE: National Drilling Company Administrative Report 92-003, 45 p. [Available through the Environment Agency_Abu Dhabi.]

Nimmo, J.R., 2006, Unsaturated zone flow processes, part 13-150 of Anderson, M.G., and others, Encyclopedia of hydrological sciences: Hoboken, N.J., Wiley, 24 p.

Osterkamp, W.R., Lane, L.J., and Menges, C.M., 1995, Techniques of groundwater recharge estimates in arid/semiarid areas, with examples from Abu Dhabi: Journal of Arid Environments, v. 31, no. 3, p. 349-369. [Also available at https://doi.org/10.1016/S0140-1963(05)80038-2.]

Papadopoulos, I.S., and Cooper, H.H., Jr., 1967, Drawdown in a well of large diameter: Water Resources Research, v. 3, no. 1, p. 241-244. [Also available at https://doi.org/10.1029/ WR003i001p00241.]

Poeter, E.P., Hill, M.C., Lu, D., Tiedeman, C.R., and Mehul, S., 2014, UCODE_2014, with new capabilities to define parameters unique to predictions, calculate weights using simulated values, estimate parameters with SVD, evaluate uncertainty with MCMC, and more: Integrated Groundwater Modeling Center Report Number GWMI 2014-02, accessed January 2018 at http://igwmc.mines.edu/freeware/ ucode/.

Remington, S.M., 1986, Groundwater quantitative study, greater Buraimi area: Sultanate of Oman Council for Conservation of Environment and Water Resources, Public Authority for Water Resources (Oman), Open-File Report 23-86, $24 \mathrm{p}$.

Rizk, Z.S., 1998, Aflaj of United Arab Emirates-Geological setting and hydrogeological characteristics: Arabian Journal for Science and Engineering, v. 23, no. 1C, p. 3-25.

Saines, M., and Ansari, S.U., 1985, Results of appraisal drilling in Zarub Gap, Buraimi Region, Oman: Sultanate of Oman, Development Council, Regional Development Committee, REC/82/12, $41 \mathrm{p}$.
Sanford, W.E., and Wood, W.W., 2001, Hydrology of the coastal sabkhas of Abu Dhabi, United Arab Emirates: Hydrogeology Journal, v. 9, no. 4, p. 358-366. [Also available at https://doi.org/10.1007/s100400100137.]

Sherif, M., Almulla, M., Shetty, A., and Chowdhury, R.K., 2014, Analysis of rainfall, PMP and drought in the United Arab Emirates: International Journal of Climatology, v. 34, no. 4, p. 1318-1328. [Also available at https://doi.org/10.1002/joc.3768.]

Statistics Center Abu Dhabi, 2010, Statistical yearbook of Abu Dhabi: Statistics Center of Abu Dhabi, 287 p., accessed December 15, 2017, at http://piketty.pse.ens.fr/files/capital21c/xls/RawDataFiles/WealthReportsEtc/SovereignFunds/AbuDhabi/ADStatisticalYearbook2010(www.adia. ae).pdf.

Tadros, S.H., and Huneidi, I., 1994, Falajes of Al Ain area, Abu Dhabi Emirate: National Drilling Company Administrative Report 94-02, 27 p.

Tawfiq, I., and Nasr, M.A., 1997, Aquifer tests in Abu Dhabi Emirate, 1988-1995: National Drilling Company Technical Report 97-01, 267 p.

United Nations, 2012, World population prospects-The 2012 revision: United Nations Population Division of the Department of Economic and Social Affairs of the United Nations Secretariat, accessed February 18, 2020, at https://www.un.org/en/development/desa/publications/ world-population-prospects-the-2012-revision.html.

U.S. Geological Survey [USGS], 2013, Bibliography of National Drilling Company-U.S. Geological Survey publications on the water resources of Abu Dhabi Emirate, 1987-2011: National Drilling Company-U.S. Geological Survey administrative report. [Available through the Environment Agency_Abu Dhabi.]

Wood, W.W., Sanford, W.E., and Al Habshi, A.R.S., 2002, Source of solutes to the coastal sabkha of Abu Dhabi: Geological Society of America Bulletin, v. 114, no. 3, p. 259-268. [Also available at https://doi.org/10.1130/00167606(2002)114<0259:SOSTTC $>2.0 . C O ; 2$.

Woodward, D.G., 1994, Contributions to a shallow aquifer study by reprocessed seismic sections from petroleum exploration surveys, eastern Abu Dhabi, United Arab Emirates: Journal of Applied Geophysics, v. 31, no. 1-4, p. 271-289. [Also available at https://doi.org/10.1016/09269851(94)90062-0.]

Woodward, D.G., and Al-Jeelani, A.H., 1993, Application of reprocessed seismic sections from petroleum exploration surveys for groundwater studies, eastern Abu Dhabi, UAE: Proceedings, Middle East Society of Petroleum Engineers, 1993 Annual Meeting, Bahrain, p. 257-265. [Also available at https://doi.org/10.2118/25538-MS.] 
For more information about this report, contact: Director, New England Water Science Center U.S. Geological Survey

10 Bearfoot Road

Northborough, MA 01532

dc_nweng@usgs.gov

or visit our website at

https://newengland.water.usgs.gov

Publishing support provided by the

Pembroke and Denver Publishing Service Centers 
